\title{
Optimization of Soil Mixtures in Bioretention Cells to Reduce Nutrient Loading to the Environment from Storm Water
}

A Thesis
presented to
the Faculty of the Graduate School
at the University of Missouri-Columbia
In Partial Fulfillment
of the Requirements for the Degree
Master of Science
JACOB NOVAK

Enos C. Inniss, Ph.D, Thesis Supervisor

December 2013 
The undersigned, appointed by the dean of the Graduate School, have examined the Thesis entitled

\title{
Optimization of Soil Mixtures in Bioretention Cells to Reduce Nutrient Loading to the Environment from Storm Water
}

\author{
presented by Jacob Novak, \\ candidate for the degree of Master of Science \\ and \\ hereby certify that, in their opinion, it is worthy of acceptance.
}

Enos Inniss, Ph.D

Kathleen Trauth, Ph.D, P.E.

Allen Thompson, Ph.D, P.E. 


\section{Dedication}

I would like to dedicate this thesis to my parents, Michael and Michelle Novak, my wife, Lauren Novak, and my brother, Joshua Novak. Without their support I would not be where I am today. 


\section{ACKNOWLEDGEMENTS}

I would like to acknowledge first and foremost, Dr. Enos Inniss for giving me the opportunity to pursue a MS degree and for his guidance. I would also like to thank my

thesis committee members: Dr. Inniss, Dr. Trauth, and Dr. Thompson for their guidance and support throughout the thesis writing process.

Second, I would like to thank the Storm Water Undergraduate Team members. They have helped run tests, compile data, retrieve samples from around Columbia, and overall have been a vast knowledgebase during the entire process. Without them this research would have not been possible. The countless hours in the lab and also in the field have shown a dedication to understanding storm water that many never get to see.

Lastly, I would like to thank all of the graduate students, colleagues, family, and friends. Without their support and guidance I am sure I would not be where I am today. 


\section{TABLE OF CONTENTS}

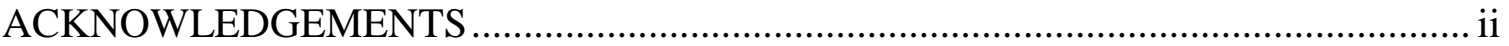

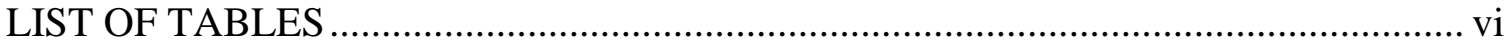

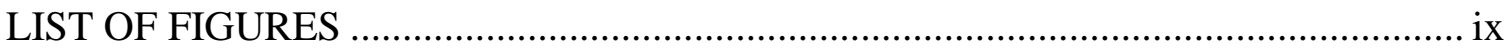

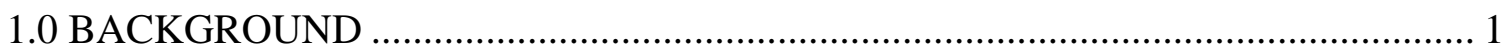

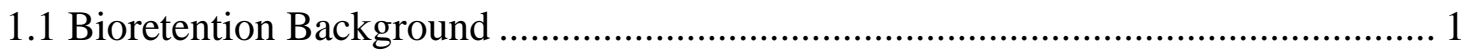

1.1.1 Background on Stormwater Management ............................................... 1

1.1.2 Background of Stormwater Management Regulations and Laws Leading to

Stormwater Management for Municipal Entities ................................................ 3

1.1.3 Best Management Practices and Low Impact Development Background ....... 10

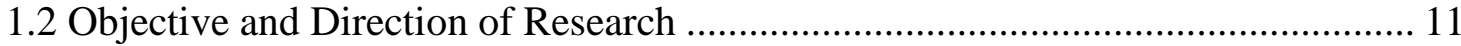

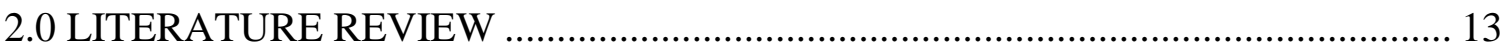

2.1 Structural Best Management Practice (BMP) Types ......................................... 13

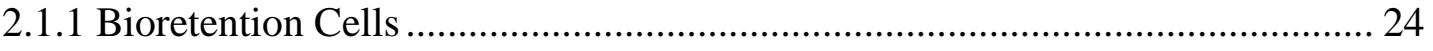

2.2 Drinking Water Treatment Residual Addition to Soils ...................................... 27

2.2.1 Typical Drinking Water Treatment Process ................................................. 27

2.2.2 Types of Drinking Water Treatment Coagulants Used ................................ 29

2.2.3 Drinking Water Treatment Coagulant Chemical Formulas........................... 31

2.2.4 Drinking Water Treatment Residual Addition to Bioretention Soil Mixes...... 33

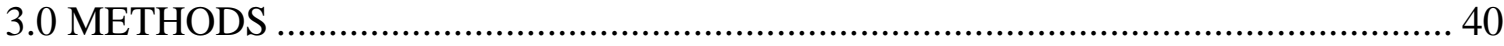


3.1 Drinking Water Treatment Residual Capacity Testing ..................................... 40

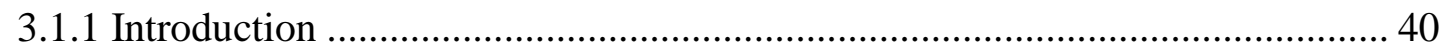

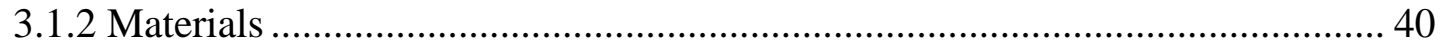

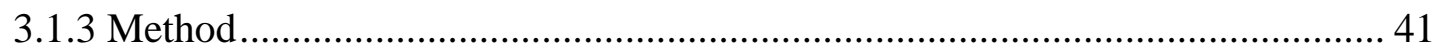

3.2 Lab Scale Soil Column Testing................................................................. 42

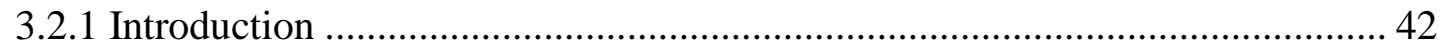

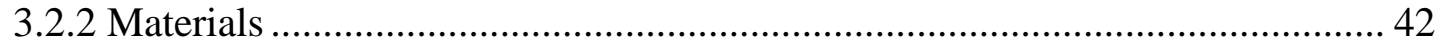

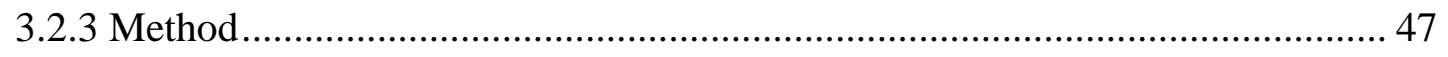

4.0 CHARACTERIZATION AND SORPTION CAPACITY .................................... 51

4.1 Types of Metals Present in Drinking Water Treatment Residual ........................ 51

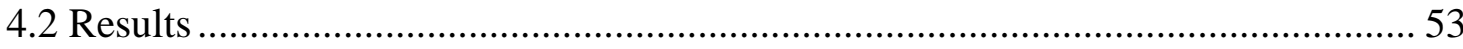

4.3 Langmuir and Freundlich Isotherm Modeling ................................................ 54

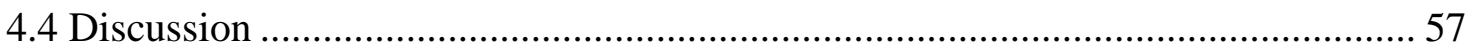

4.4.1 Phosphorous Reduction in Stormwater Analysis ...................................... 58

5.0 LAB SCALE BIORETENTION MEDIA PERFORMANCE ................................. 59

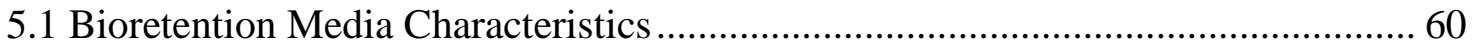

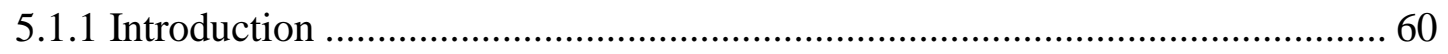

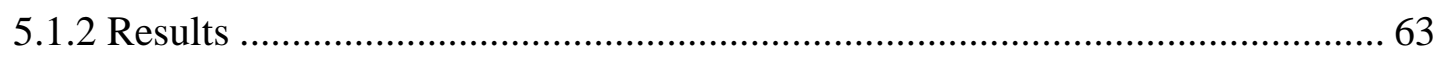

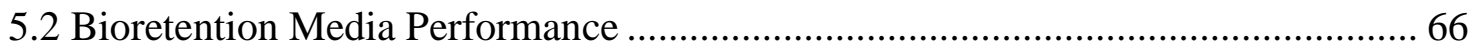

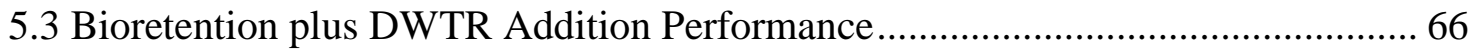




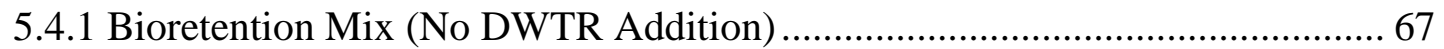

5.4.2 Bioretention Mix Plus Drinking Water Treatment Residuals ........................ 70

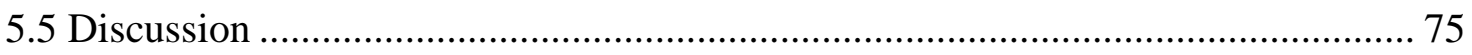

6.0 SUMMARY AND FUTURE RESEARCH DIRECTION ................................... 77

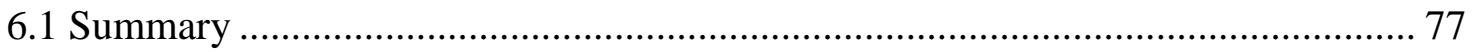

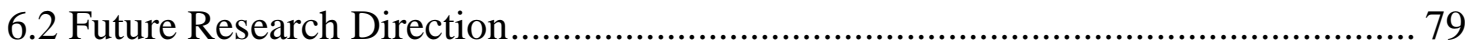

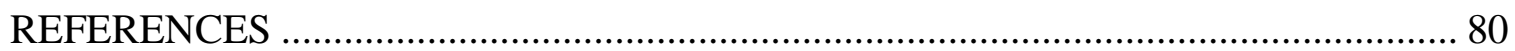

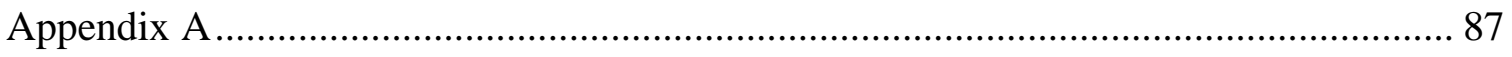

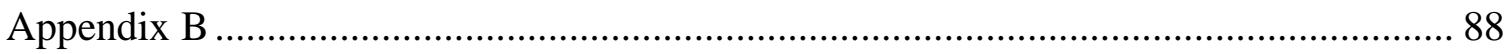

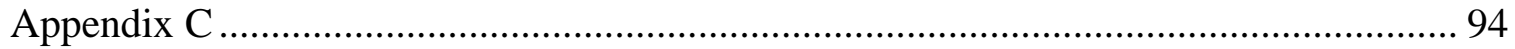

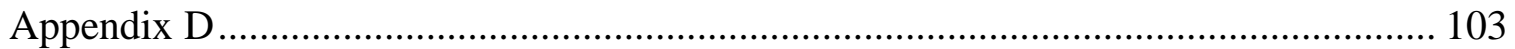




\section{LIST OF TABLES}

Table 2- 1: General Characteristics of Different BMP Types ....................................... 14

Table 2- 2: Feasibility of Amendments; Adapted from Fenton et al. (2011) ................... 35

Table 3- 1: Bioretention Soil Mix (BSM) and Water Treatment Residual (WTR) Mixing

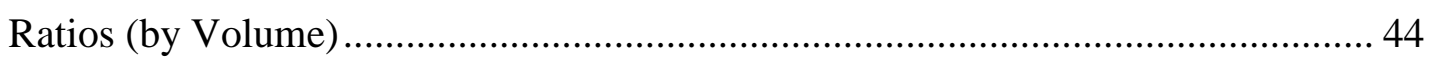

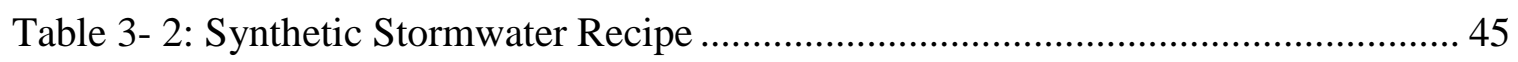

Table 3- 3: Changes to Stormwater Recipe for the Bioretention Mix plus WTR............ 46

Table 4- 1: Drinking Water Treatment Residual Sampling Data ................................ 52

Table 4- 2: Adsorption Isotherm Data - Langmuir and Freundlich Models .................... 56

Table 4- 3: Maximum Phosphorus Sorption Capacities and Event Based Need of DWTR

to Sequester All of the Phosphorous ............................................................. 58

Table 5- 1 Lag Times between Pump Turn-On and Water Flow from Cell ..................... 68

Table 5- 2: Ca-, Fe-, and Al-DWTR Addition Average Effluent Flow from Cells .......... 76

Table B- 1: Phosphorous Sorption Loading Values after 24 Hours for Calcium and Ferric

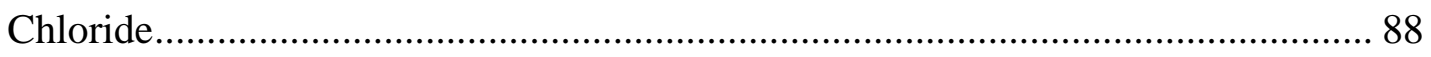

Table B- 2: Phosphorous Sorption Loading Values after 24 Hours for PolyAluminum

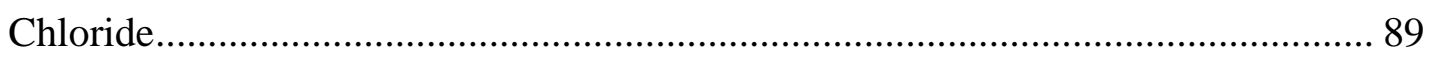

Table B- 3: Phosphorous Sorption Loading Values after 24 Hours for Aluminum Sulfate

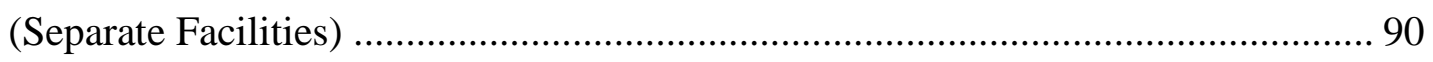

Table C- 1: Test \# 1, Effluent Phosphorous concentration as a function of time for $100 \%$

Bioretention Soil Mix, 0.4 mg/L Influent Phosphorous at 60mL/min ................... 97

Table C- 2: Test \# 2, Effluent Phosphorous concentration as a function of time for $100 \%$

Bioretention Soil Mix, 0.4 mg/L Influent Phosphorous at 60mL/min ................... 97 
Table C- 3: Test \# 3, Effluent Phosphorous concentration as a function of time for $100 \%$ Bioretention Soil Mix, $0.4 \mathrm{mg} / \mathrm{L}$ Influent Phosphorous at 60mL/min. 98

Table C- 4: Test \# 4, Effluent Phosphorous concentration as a function of time for $100 \%$

Bioretention Soil Mix, $9.6 \mathrm{mg} / \mathrm{L}$ Influent Phosphorous at $60 \mathrm{~mL} / \mathrm{min}$...... 98

Table C- 5: Bioretention Cell Tests 1 through 3 Error Analysis of Effluent Phosphorus concentrations - $100 \%$ Bioretention Mix, $0.4 \mathrm{mg} / \mathrm{L}$ of influent phosphorous at $60 \mathrm{~mL} / \mathrm{min}$

Table C- 6: Test 6, Ca DWTR Pump Turn On and Turn Off Times during Testing at 5\%, $10 \%$, and $20 \%$ DWTR Addition 99

Table C- 7: Test 7, Fe DWTR Pump Turn On and Turn Off Times during Testing at 5\%, 10\%, and 20\% DWTR Addition 100

Table C- 8: Test 8, Al DWTR Pump Turn On and Turn Off Times during Testing at 5\%, $10 \%$, and $20 \%$ DWTR Addition 100

Table C- 9: Ca-, Fe-, and Al-DWTR Addition Lag Times between Pump Turn-On and Water Flow from Cell 101

Table C- 10: Test \# 6, Effluent Phosphorus when the total mix is 5\%, 10\%, and 20\% CaDWTR, $6.2 \mathrm{mg} / \mathrm{L}$ Influent Phosphorous at 60mL/min; Cell 1 had intermittent flow 101

Table C- 11: Test \# 7, Effluent Phosphorus when the total mix is 5\%, 10\%, and $20 \% \mathrm{Fe}$ DWTR, $6.2 \mathrm{mg} / \mathrm{L}$ Influent Phosphorous at $60 \mathrm{~mL} / \mathrm{min}$ 102

Table C- 12: Test \# 8, Effluent Phosphorus when the total mix is 5\%, 10\%, and 20\% AlDWTR, $6.2 \mathrm{mg} / \mathrm{L}$ Influent Phosphorous at 60mL/min 102 
Table D- 1: Size Characterization of DWTR Compared to a BMP Soil. Pre - Before Column Testing, Post - After Column Testing

Table D- 2: Extractable Bases by $\mathrm{NH}_{4} \mathrm{Cl}$ of DWTR Compared to a BMP Soil. Pre -

Before Column Testing, Post - After Column Testing....................................... 104

Table D- 3: Cation Exchange Capacity of DWTR Compared to a BMP Soil. Pre - Before Column Testing, Post - After Column Testing 105

Table D- 4: pH, Plant Available Phosphorus, Total Nitrogen, and Conductivity of DWTR Compared to a BMP Soil. Pre - Before Column Testing, Post - After Column Testing. 106 


\section{LIST OF FIGURES}

Figure 1- 1: One Type of Impervious Surface - Parking Lots (Wikipedia, 2006b) ......... 10

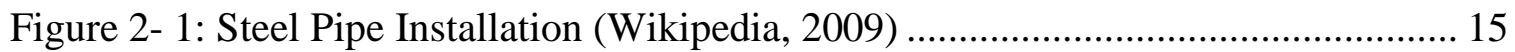

Figure 2- 2: One Type of Porous Paver (Wikipedia, 2011) ......................................... 16

Figure 2- 3 Constructed Vegetated Swale (Wikipedia, 2002) ..................................... 17

Figure 2- 4: Typical Rain Garden Cross Section with Optional Drain at Bottom (Stange,

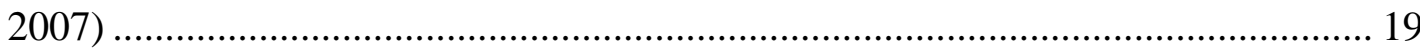

Figure 2- 5: Riparian Buffer Area near Lake Erie (Wikipedia, 2005).......................... 20

Figure 2- 6: Retention Pond Near a Developed Area (Wikipedia, 2007) ...................... 21

Figure 2- 7: Typical Residential or Small Community Detention Area (Wikipedia, 2006a)

Figure 2- 8: Wetland in Frontenac National Park (Wikipedia, 2008)............................ 23

Figure 2- 9: Typical bioretention cross section from St. Louis MSD (St. Louis

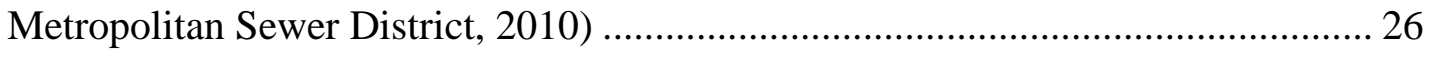

Figure 2- 10: Basic Layout of a Drinking Water Treatment Plant ............................... 28

Figure 2- 11: Graphical Representation of a Colloid with a Zeta Potential (Wikipedia,

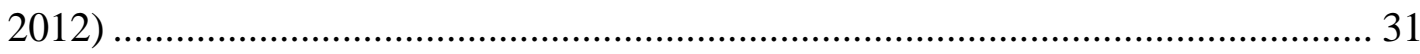

Figure 3- 1 General lab-scale bioretention setup ................................................... 43

Figure 3- 2: General Setup used in All Tests of PVC Column and Associated Equipment

Figure 4- 1: Sorption Loading of Phosphorous After 24 Hour Equilibrium Period.

Phosphorous solution concentrations of 5, 10, 25, 50, 100, and $200 \mathrm{mg} / \mathrm{L} \ldots \ldots \ldots \ldots . . . . .54$ 
Figure 5- 1: Bioretention Cell Test 2 - 100\% Bioretention Mix, 0.4mg/L of influent phosphorous at $60 \mathrm{~mL} / \mathrm{min}$ 70

Figure 5- 2: Bioretention Cell Tests 1 through 3 Error Analysis - 100\% Bioretention Mix, $0.4 \mathrm{mg} / \mathrm{L}$ of influent phosphorous at $60 \mathrm{~mL} / \mathrm{min}$ 70

Figure 5- 3: Bioretention Cell Test 5-80\% BSM + 20\% Calcium DWTR Addition, 0 $\mathrm{mg} / \mathrm{L}$ of influent phosphorous at $60 \mathrm{~mL} / \mathrm{min}$ 71

Figure 5- 4: Bioretention Cell Test 6 - 5, 10, and 20\% Calcium DWTR Addition, 6.2 $\mathrm{mg} / \mathrm{L}$ of influent phosphorous at $60 \mathrm{~mL} / \mathrm{min}$ 72

Figure 5- 5: Bioretention Cell Test 7 - 5, 10, and 20\% Iron DWTR Addition, $6.2 \mathrm{mg} / \mathrm{L}$ phosphorus in influent water at $60 \mathrm{~mL} / \mathrm{min}$ 73

Figure 5- 6: Bioretention Cell Test 8 - 5, 10, and 20\% Aluminum DWTR Addition, 6.2 $\mathrm{mg} / \mathrm{L}$ phosphorus in influent water at $60 \mathrm{~mL} / \mathrm{min}$ 74

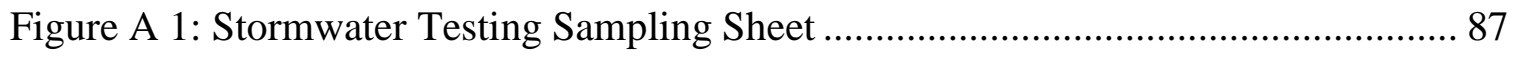

Figure B- 1: Langmuir and Freundlich Isotherm Modeling for Lime DWTR 90

Figure B- 2: Langmuir and Freundlich Isotherm Modeling for Ferric Chloride DWTR . 91 Figure B- 3: Langmuir and Freundlich Isotherm Modeling for Polyaluminum Chloride DWTR 91

Figure B- 4: Langmuir and Freundlich Isotherm Modeling for (Retest) Polyaluminum Chloride DWTR

Figure B- 5: Langmuir and Freundlich Isotherm Modeling for Polyaluminum + CuSO4 Chloride DWTR 92

Figure B- 6: Langmuir and Freundlich Isotherm Modeling for Aluminum Sulfate + PAC + Drying Polymer DWTR 93 
Figure C- 1: Bioretention Cell Test $1-100 \%$ Bioretention Mix, 0.4mg/L of influent phosphorous at $60 \mathrm{~mL} / \mathrm{min}$ 94

Figure C- 2: Bioretention Cell Test 2 - 100\% Bioretention Mix, 0.4mg/L of influent phosphorous at 60mL/min; $\mathrm{C} 290$ min point removed due to being unknown outlier

Figure C- 3: Bioretention Cell Test 3 - 100\% Bioretention Mix, 0.4mg/L of influent phosphorous at $60 \mathrm{~mL} / \mathrm{min}$ 95

Figure C- 4: Bioretention Cell Test 4 - 100\% Bioretention Mix, 9.6mg/L of influent phosphorous at $60 \mathrm{~mL} / \mathrm{min}$ 96 


\subsection{BACKGROUND}

\subsection{Bioretention Background}

\subsubsection{Background on Stormwater Management}

In the late 1800s and early 1900s stormwater management was handled differently from how it is handled today (Environmental Protection Agency, 2012c). Previously stormwater management included installing a sewer to get stormwater away from a structure as quickly as possible. This may be necessary for some situations, but for the bulk of the situations, it causes many problems on the downstream side of the discharge pipe. The water coming out of the pipe is typically at a very high velocity and very large discharge. This causes mass movement of sediments at the end of the pipe and throughout the stream channel. The early stormwater discharge channels were not protected from large flows and velocities. Later designs incorporated better protection but there were still issues with stormwater causing mass sediment movement. With more infrastructure came more impervious surface and no upgrades in the stormwater management. Since there were minimal upgrades to the receiving streams, the stormwater started to cause channel widening, movement of sediment, and many other negative effects to the stream. Along with physical effects to the stream bed, many chemical constituents are included in the stormwater. The chemicals constituents in stormwater may include many things such as motor oil, grease, fertilizer, animal waste, trash, and household chemicals (Environmental Protection Agency, 2003). Any additional chemicals in the receiving stream can cause an imbalance, which can lead to additional growth of plants, aquatic animal death, and overall poor stream water quality. With both 
of these concerns in mind Best Management Practices (BMPs) and Low Impact Development (LID) manuals and practices were created (Environmental Protection Agency, 2012a, 2013b). The BMP and LID practices both promote good stewardship for the environment through stormwater management. The LID manual focuses on returning the post construction or development hydrograph to a pre-development hydrograph.

"LID is an approach to land development (or re-development) that works with nature to manage stormwater as close to its source as possible. LID employs principles such as preserving and recreating natural landscape features, minimizing effective imperviousness to create functional and appealing site drainage that treat stormwater as a resource rather than a waste product. Applied on a broad scale, LID can maintain or restore a watershed's hydrologic and ecological functions.” (Environmental Protection Agency, 2013b)

Best management practice (BMP) is a term used to describe a type of stormwater pollution control and can range from a pipe to a wetland as structural BMPS or preserving open space to protecting stream corridors as non-structural BMPs.

"Stormwater BMPs are techniques, measures or structural controls used to manage the quantity and improve the quality of stormwater runoff. The goal is to reduce or eliminate the contaminants collected by stormwater as it moves into streams and rivers." (Environmental Protection Agency, 2013a)

Instead of using the concept of getting rid of stormwater quickly without worrying about the effects, BMPs and LIDs use the concept of managing stormwater through infiltration and sizing infrastructure with the discharge in mind. 
Since the passage of the Clean Water Act in 1972, much effort has been placed on stream quality improvements through the national pollution discharge elimination program (NPDES) which permits how much of a total maximum daily load (TMDL) of pollutants a waterway can receive and still safely meet water quality standards. Through the removal of point source discharges or limiting the amount of chemical constituents coming from the point source, stream quality improved but stormwater primarily from diffuse or non-point sources was still not well managed. Since then federal and state agencies have revised standards to limit the effects from non-point sources that are collected into an engineered system such as a storm sewer (Environmental Protection Agency, 2013c). To quell this problem, LID and BMP practices were used. Through retention and detention many of the chemical constituents along with general trash are reduced. Since implementation of these LID and BMP practices, stream quality in many areas has improved and many federal and state goals can be met.

\subsubsection{Background of Stormwater Management Regulations and Laws Leading to Stormwater Management for Municipal Entities}

Best management practices (BMPs) and are becoming a reliable way to reduce stormwater impacts whether physical or chemical. One of the first water quality permitting systems was the Deposit of Refuse in Navigable Waters Generally ("Rivers and Harbors Act," 1899). This established precedence that non-liquid waste could not be dumped into a navigable waterway unless there was a permit issued. Other, similar, laws were made so that navigable waterways would not be impeded. Between 1899 and the 1960's, there was not much change to the laws about discharge into the waterways. Many court cases came through the United States court system but two cases against large 
companies started a water quality movement. United States, Petitioner, v. Republic Steel Corp. et. al. ("United States, Petitioner, v. Republic Steel Corp. et. al.," 1960) and United States, Appellant, v. Standard Oil Company ("United States, Appellant, v. Standard Oil Company," 1966) both were argued using the Rivers and Harbors Act but were dually pushing for water quality as well. The Republic Steel Corp. case was centered around how much particulate matter was leaving industrial steel plants without a permit. Republic Steel Corp. and other mills on the Calumet River had setup settling basins before their discharge point in the river, but the US Army Corps of Engineers (USACE) found the channel to still be silting in. Republic Steel Corp. et. al. argued that the amount of particulate matter leaving their plant was negligible and not a hindrance to the waterway. In contrast, the US Army Corps of Engineers found that a large percentage of the siltation was from the mills on the Calumet River. The court ruled in the favor of the United States and required that the channel be cleared so river traffic is not impeded. Although river traffic and navigation was the driving factor for this case, the water quality of the stream was also improved. In the Standard Oil case, Standard Oil had allegedly dumped a large quantity of 100 octane fuel into a waterway. The main focus of the argument was about the dumping of the oil but the argument was centered around how the oil impaired the waterway. The Rivers and Harbors act did not cover this case because the oil was not found to be 'refuse matter' but rather a consumable. The case was handled outside of court and it was found that the dumping was caused by a faulty valve near the river. 
Mr. Justice Douglas wrote the open of the court and said:

"This case comes to us at a time in the Nation's history when there is greater concern than ever over pollution-one of the main threats to our free-flowing rivers and to our lakes as well. The crisis that we face in this respect would not, of course, warrant us in manufacturing offenses where Congress has not acted nor in stretching statutory language in a criminal field to meet strange conditions. But whatever may be said of the rule of strict construction, it cannot provide a substitute for common sense, precedent, and legislative history. We cannot construe $\S 13$ of the Rivers and Harbors Act in a vacuum." -Douglas (1966)

Amid a growing attitude of environmental stewardship in the United States during the late 1960s, in 1970 President Richard Nixon signed the National Environmental Policy Act ("NEPA," 1969) which laid the framework for improvements to the environment and also created the Council on Environmental Quality ("CEQ," 1970). The role of the CEQ is to relay information and professional opinions about environmental topics to the President. 
Within the NEPA law, 6 goals are outlined, similar to the "sustainability" goals of the early 2000s:

"(1) Fulfill the responsibilities of each generation as trustee of the environment for succeeding generations

(2) Assure for all Americans safe, healthful, productive, and esthetically and culturally pleasing surroundings;

(3) Attain the widest range of beneficial uses of the environment without degradation, risk to health or safety, or other undesirable and unintended consequences;

(4) Preserve important historic, cultural, and natural aspects of our national heritage, and maintain, wherever possible, an environment which supports diversity and variety of individual choice;

(5) Achieve a balance between population and resource use which will permit high standards of living and a wide sharing of life's amenities; and

(6) Enhance the quality of renewable resources and approach the maximum attainable recycling of depletable resources." ("NEPA," 1969)

Through the use of these six goals the federal government ensures that environmental impacts are considered when any development or changes are made. These six goals also keep a balance between environmental impacts and the public's interest in new development. Again in 1970 President Nixon signed the "Reorganization Plan of 1970" ("Reorginization Plan of 1970," 1970) which formally combined the power of many government agencies into one government organization named the United States Environmental Protection Agency (or EPA). This incorporation of power streamlined the 
research, public outreach, enforcement, and policy revision process pertaining to pollutants in the environment.

In 1972, amendments to the Federal Water Pollution Control Act enabled the government to reduce or eliminate pollution entering surface or ground water sources. The 1972 amendments were popularly called the 'Clean Water Act' ("CWA," 1972) and ushered in the National Pollution Discharge Elimination System ("NPDES," 1972) which only allowed permitted entities the right to release water that is of a prescribed quality into waters of the United States. Since the passing of the CWA and implementation of the NPDES program, many changes have been made to make tighter standards and stricter laws on what can be released into the environment whether through air or water.

A subset of the NPDES permit is "Municipal and Industrial Stormwater Discharges” ("Municipal and Industrial Stormwater Discharges," 1994) which limited how much stormwater and at what quality municipalities could discharge stormwater. Originally the act had only applied to industry but the EPA found that it was not only industries contributing to the low stormwater quality problem. This ruling therefore affected the following categories: 
“(A) A discharge with respect to which a permit has been issued under this section before February 4, 1987.

(B) A discharge associated with industrial activity.

(C) A discharge from a municipal separate storm sewer system serving a population of 250,000 or more.

(D) A discharge from a municipal separate storm sewer system serving a population of 100,000 or more but less than 250,000.

(E) A discharge for which the Administrator or the State, as the case may be, determines that the stormwater discharge contributes to a violation of a water quality standard or is a significant contributor of pollutants to waters of the United States." ("Municipal and Industrial Stormwater Discharges," 1994)

For municipalities, the stormwater permit applies as follows:

“(B) Municipal discharge permits for discharges from municipal storm sewers-

(i) may be issued on a system- or jurisdiction-wide basis;

(ii) shall include a requirement to effectively prohibit non-stormwater discharges into the storm sewers; and

(iii) shall require controls to reduce the discharge of pollutants to the maximum extent practicable, including management practices, control techniques and system, design and engineering methods, and such other provisions as the Administrator or the State determines appropriate for the control of such pollutants." ("Municipal and Industrial Stormwater Discharges," 1994) 
According to this subsection stormwater permits may affect multiple municipalities within a system at one time and also limits the amount of prescribed pollutants in the effluent stormwater. Subsection B ushered in the EPA's guidance on how to effectively control and reduce stormwater pollution.

To implement the NPDES program on stormwater, the EPA created the “Municipal Separate Storm Sewer System” (MS4) permit program. This program serves two purposes: eliminate combined sewer outflows (CSOs) and reduce harmful pollutants coming from a stormwater system. Two phases for the MS4 permits were created:

"Phase I: issued in 1990, requires medium and large cities or certain counties with populations of 100,000 or more to obtain NPDES permit coverage for their stormwater discharges. There are approximately 750 Phase I MS4s.

Phase II: issued in 1999, requires regulated small MS4s in urbanized areas, as well as small MS4s outside the urbanized areas that are designated by the permitting authority, to obtain NPDES permit coverage for their stormwater discharges. There are approximately 6,700 Phase II MS4s.” - Environmental Protection Agency (2013c)

When an entity (person, city, agency, etc) receives an MS4 permit, the entity must create and implement a Stormwater Management Plan (SWMP). The SWMP includes how the entity will accomplish the limits set by the MS4 permit. To help these entities, the EPA created the Stormwater Program (SP) to educate the public about implementation of stormwater Best Management Practices (BMPs) which also 
encompass Low Impact Development (LID) practices (Environmental Protection Agency, 2012e).

\subsubsection{Best Management Practices and Low Impact Development Background}

BMP guides have been created to help communities plan for excess stormwater runoff. Stormwater runoff is generated when impervious surfaces (Figure 1-1) do not allow infiltration. Stormwater runoff, although separate from wastewater, can include high amounts of harmful bacteria, oil, grease, trash, and nutrients in the "first flush". The first flush is typically the first part (10\% to $20 \%)$ of the storm runoff volume that includes the contaminants that are easily mobilized by rain water flowing over the impervious surface. To help control what undesirable material the water carries to the receiving stream, various BMPs could be used. These structural or engineered BMPs help by filtering out larger materials and provide some treatment through biological or plant activity within the unit. Although BMPs can be effective at filtering many pollutants, when discussing bioretention specifically, phosphorous reduction is not always achieved (Dietz \& Clausen, 2005). To reduce the effect of excess phosphorous in the effluent water, this research explored the topic of addition of drinking water treatment residuals (DWTRs).

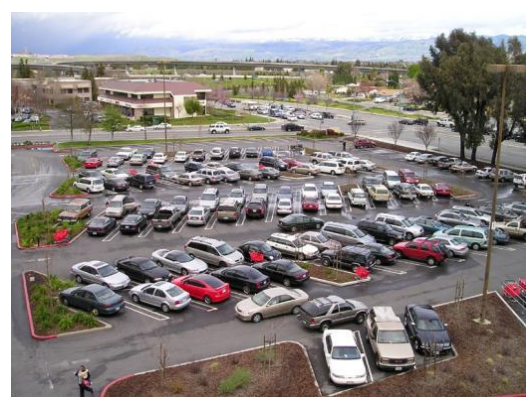

Figure 1- 1: One Type of Impervious Surface - Parking Lots (Wikipedia, 2006b) 


\subsection{Objective and Direction of Research}

Phosphorous is typically added to the soil in the form of fertilizers, bio-solids, and manure can runoff and pollute water supplies via surface runoff (Agyin-Birikorang et al., 2007). Large amounts of phosphorous and nitrate in water can cause detrimental effects to the water ecosystem due to the growth of algae and, in the long term, eutrophication. On land, the accumulation of phosphorous is typically not damaging to the soil fertility or to the plants inhabiting the soil (Agyin-Birikorang et al., 2009). The $\mathrm{Ca}, \mathrm{Fe}$, and $\mathrm{Al}$ were chosen because each are by-products from drinking water treatment facilities (DWTFs) and are typically sent to the landfill, rather than being reused. Drinking-water treatment residuals are primarily sediment, metal (aluminum, iron or calcium) oxide/hydroxides and activated carbon removed from the water during the water purification process. Polymers are sometimes added to aide in the dewatering processs (Agyin-Birikorang et al., 2009). There has been some research done by other scholars in respect to applying DWTRs to agriculture plots but not much done when applying DWTRs to bioretention cells (Agyin-Birikorang et al., 2007; Agyin-Birikorang et al., 2009; Dayton et al., 2001; Dayton et al., 2003; Fenton et al., 2011). 
The objective of this research is to test the performance of Aluminum (Al), Calcium $(\mathrm{Ca})$, and Ferric $(\mathrm{Fe})$ drinking water treatment residuals (DWTRs) in the uptake of orthophosphate (phosphorous) in an urban scenario. To test this objective a two pronged approach was taken:

1. Test the DWTR phosphorous uptake alone (Chapter 4)

a. Use 24 hour equilibrium testing

2. Test the DWTR phosphorous uptake when mixed with a bioretention media (Chapter 5)

a. Test the bioretention media with no addition of DWTR

b. Use same bioretention mix as the initial (no DWTR) bioretention media testing and mix at 5\%,10\%, and 20\% (by volume) of DWTR into bioretention media 


\subsection{LITERATURE REVIEW}

\subsection{Structural Best Management Practice (BMP) Types}

The term structural BMP covers a wide range of stormwater treatment options (Luoni et al., 2011). A BMP could range from a concrete pipe to a wetland or something in between. The flexibility allowed with the term BMP makes it easy to design with a wide range of options for any situation. In many situations multiple BMPs would be chosen to attain a stormwater treatment goal. One scenario could be a pervious paver parking lot with a cistern underneath. After a rain event, the cistern slowly drains to a rain garden which then connects to a concrete pipe. The concrete pipe would then carry the water to a wetland and eventually it would reach a stream or a larger water body. This type of "treatment train" is very common in design. A general outline of the characteristics of each type of BMP is outlined in Table 2- 1 . Through the rest of this subchapter, different categories of BMPs will be discussed. (Luoni et al., 2011) 
Table 2- 1: General Characteristics of Different BMP Types

\begin{tabular}{|c|c|c|c|c|}
\hline Type of BMP & $\begin{array}{l}\text { Conveyance/ } \\
\text { Filter Speed }\end{array}$ & $\begin{array}{l}\text { Treatment of } \\
\text { Stormwater }\end{array}$ & $\begin{array}{c}\text { Treatment } \\
\text { Mechanism }\end{array}$ & Best Use(s) \\
\hline Pipe & Fast & Minimal & $\begin{array}{c}\text { Possible to } \\
\text { filter larger } \\
\text { debris at } \\
\text { influent side }\end{array}$ & $\begin{array}{c}\text { Conveyance of } \\
\text { Stormwater }\end{array}$ \\
\hline $\begin{array}{l}\text { Porous Type } \\
\text { Treatment }\end{array}$ & $\begin{array}{l}\text { Medium to } \\
\text { Fast }\end{array}$ & Marginal & $\begin{array}{l}\text { Filters } \\
\text { particulate } \\
\text { matter }\end{array}$ & $\begin{array}{l}\text { Parking Lots; } \\
\text { Sidewalks }\end{array}$ \\
\hline $\begin{array}{l}\text { Vegetated } \\
\text { Swale }\end{array}$ & $\begin{array}{l}\text { Medium to } \\
\text { Fast }\end{array}$ & $\begin{array}{c}\text { Marginal to } \\
\text { Excellent }\end{array}$ & $\begin{array}{c}\text { Reduces } \\
\text { particulate by } \\
\text { slowing water }\end{array}$ & $\begin{array}{c}\text { Along } \\
\text { roadways; } \\
\text { Natural choice } \\
\text { to pipe }\end{array}$ \\
\hline $\begin{array}{c}\text { Riparian Buffer } \\
\text { Zone }\end{array}$ & $\begin{array}{l}\text { Medium to } \\
\text { Fast }\end{array}$ & Excellent & $\begin{array}{c}\text { Reduces } \\
\text { particulate by } \\
\text { slowing water; } \\
\text { Allows uptake } \\
\text { of nutrients by } \\
\text { plants }\end{array}$ & $\begin{array}{l}\text { Along a river } \\
\text { or stream } \\
\text { corridor }\end{array}$ \\
\hline $\begin{array}{l}\text { Rain Garden/ } \\
\text { Bioretention }\end{array}$ & $\begin{array}{l}\text { Slow to Fast; } \\
\text { Soil Conditions } \\
\text { dictate }\end{array}$ & Excellent & $\begin{array}{c}\text { Filters } \\
\text { particulate } \\
\text { matter; } \\
\text { Allows uptake } \\
\text { of nutrients by } \\
\text { plants }\end{array}$ & $\begin{array}{l}\text { Private or } \\
\text { Commercial } \\
\text { Lots; } \\
\text { Sized to meet } \\
\text { need }\end{array}$ \\
\hline Wetland & Slow & Excellent & $\begin{array}{c}\text { Filters } \\
\text { particulate } \\
\text { matter; } \\
\text { Allows uptake } \\
\text { of nutrients by } \\
\text { plants; } \\
\text { Habitat for } \\
\text { wildlife in } \\
\text { general }\end{array}$ & $\begin{array}{l}\text { Large areas at } \\
\text { or near ground } \\
\text { water level }\end{array}$ \\
\hline
\end{tabular}


Pipes

Conveyance of stormwater by pipe has been very popular since pipes were created. Pipes are easy to place in the ground, relatively easy to maintain, and come in many sizes from various manufacturers (Figure 2- 1). Pipes convey stormwater very quickly from the site to another location with minimal work and also come in a variety of types such as concrete, PVC, HDPE, cast iron, clay, steel. The main problem with pipe for stormwater conveyance is there is minimal treatment of the stormwater before it reaches a stream, river, or water body. This can be troublesome since treatment is almost always required to meet the permitted standards. With this in mind, other treatment options can be effective but not as effective as a pipe with respect to speed of conveyance (Environmental Protection Agency, 2012d).

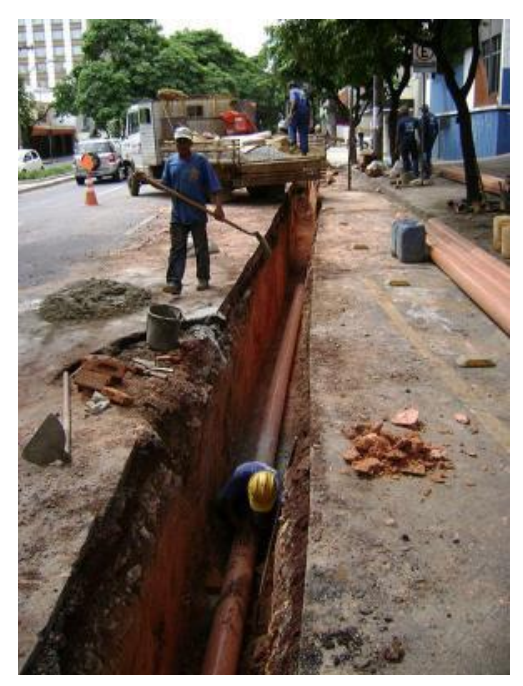

Figure 2- 1: Steel Pipe Installation (Wikipedia, 2009) 


\section{Porous type treatments}

Porous type treatments can include pavers, concrete, glass, asphalt, and many other media. Porous type treatments have been around since bricks were laid on the ground with spaces in between. Although today's types of porous pavers are made of different constituents and laid differently, they worked in the same ways, to allow water into the ground in paved area. Newer technologies have come out such as porous asphalt and porous concrete (Figure 2-2). These types of porous treatments work by having pathways which water can move through the layer of concrete or asphalt. Although it works well for large areas, problems may arise when the pores become clogged with sediment. These different types of treatments can provide varying aesthetic qualities along with some treatment of stormwater. The downside to this treatment is the low amount of water they can handle and possible clogging of the pores. The positive side of this treatment is the ability to treat some of the stormwater flow through sediment filtering action and also the ability to infiltrate water into the soil profile (Sansalone et al., 2008).

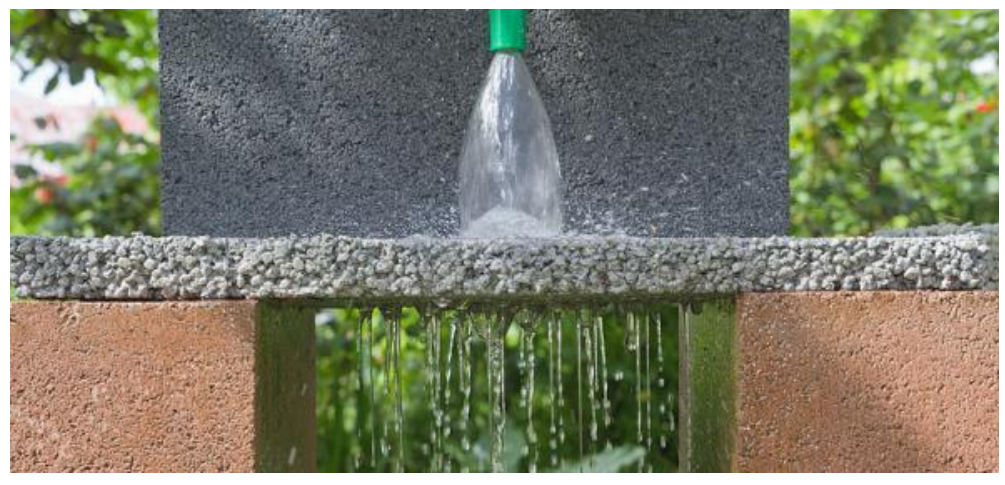

Figure 2- 2: One Type of Porous Paver (Wikipedia, 2011) 


\section{Vegetated swales}

Vegetated swales can also be called vegetated ditches and are typically used in the conveyance of stormwater similar to a pipe. Vegetated swales may carry water from one BMP to another or just run along the side of the road and concentrate stormwater flow and take it to a water body (Figure 2-3). The vegetated swale is an earthen channel that is covered in some type of vegetation and is typically seen along the sides of the road, on the sides of agriculture fields, or connecting waterways. Typical maintenance for a maintained vegetated swale may include mowing, removal or deposits, and repair when gullies appear within the channel. If maintenance is not performed the vegetated swale may not work as intended. One example would be a gully forming in the bottom of the channel. The gully would not allow vegetation to grow and erosion would start to form. In that case, the vegetated swale would actually be releasing more sediment than storing. Vegetated swales can provide some treatment of stormwater with respect to suspended solids removal and limited nutrient removal (Barrett et al., 1998). This type of treatment would be preferred over a pipe, but with space limitations it may not be possible.

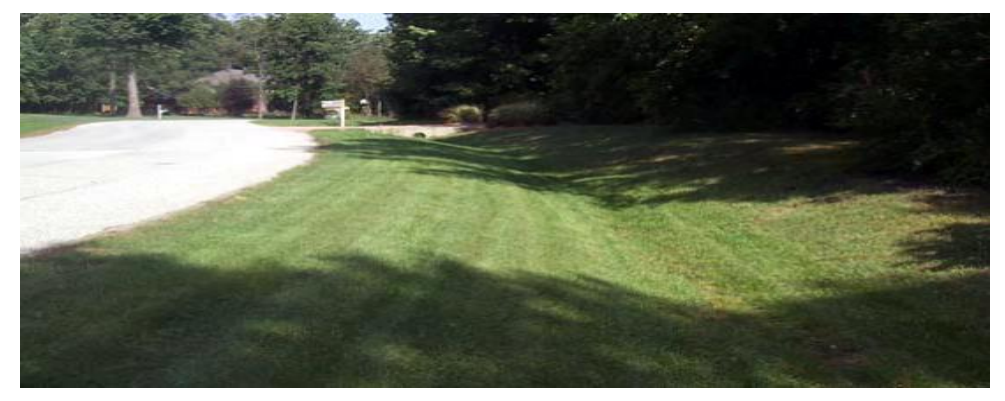

Figure 2- 3 Constructed Vegetated Swale (Wikipedia, 2002) 
Rain gardens and bioretention cells

The terms "rain garden" and "bioretention cell" can be used interchangeably. The main perceived difference between them is size. The term "rain garden" is typically used for an individual homeowner's lot while the term "bioretention cell" is used on larger scale project such as community areas or commercial lots (Clark et al., 2008;

Environmental Protection Agency, 1999). A bioretention cell is typically characterized by a small to medium sized excavated bowl in the ground. The excavated bowl is filled with a specified soil mix to promote infiltration of stormwater into the ground (Figure 2-4). The stormwater is also filtered through the soil mix providing suspended solids removal along with some nutrient removal. To enhance nutrient removal, plants may be added to the cell. The addition of plants also helps stabilize the soil mix so it is less likely to form gullies or wash out during rain events. In areas where there is not much conveyance in the native soils, a perforated drain may be added to the bottom to assist with water drainage during storm events. If the drain were not in place, the cell might not empty therefore causing a small pond to form therefore rendering it useless. If a bioretention cell does fill up with water during an event, it typically is drained by using an overflow drain placed at a set elevation. This ensures that the surrounding area does not flood. Bioretention offers treatment of nutrients and suspended solids through the filtering action of the bioretention soil media and interaction with plants. The bioretention cells must be designed using runoff area and a target rain storm (i.e. 1 year, 5 year or 10 year) or it will not function properly, e.g., could overflow regularly. Also, bioretention is not a good choice for conveyance of stormwater as the water cannot move across it easily like a pipe or vegetated swale. 


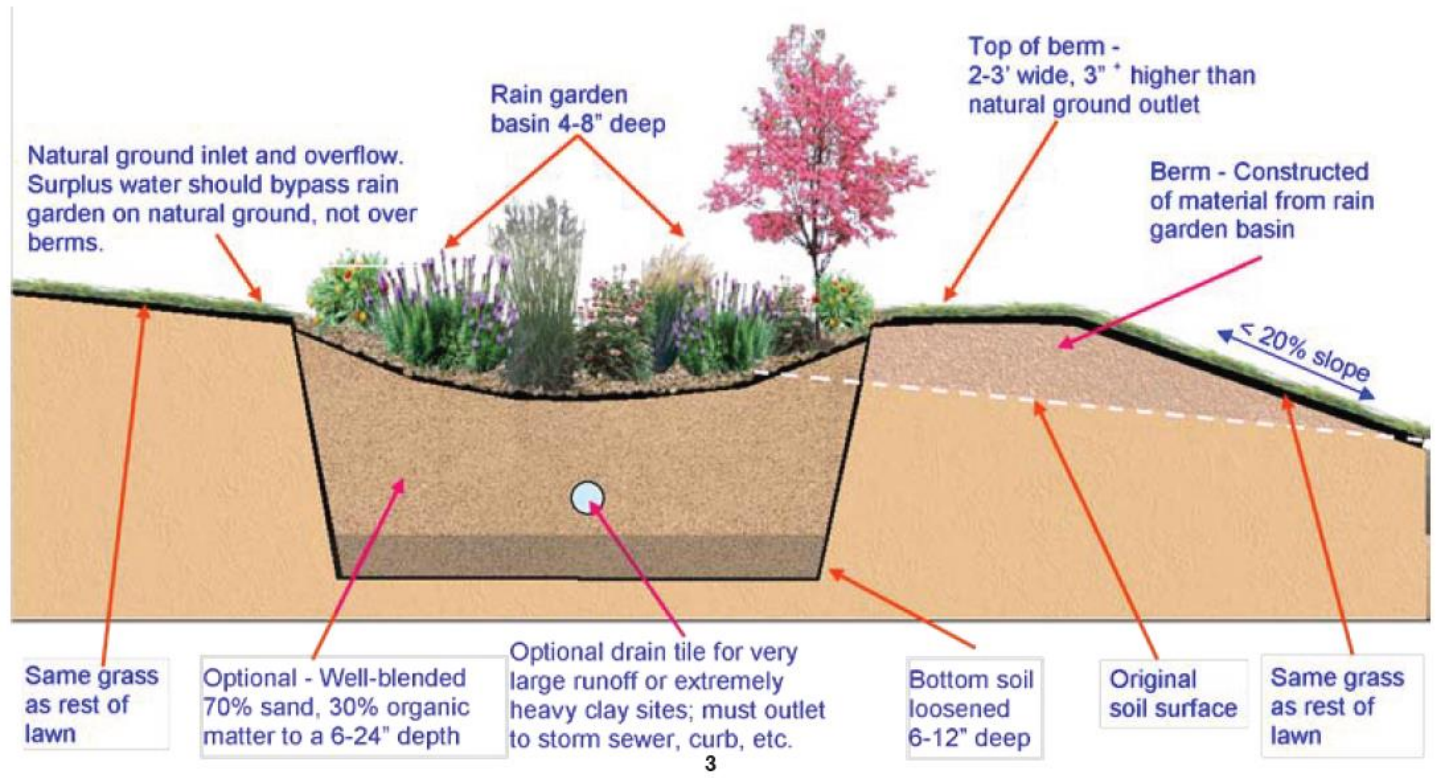

Figure 2- 4: Typical Rain Garden Cross Section with Optional Drain at Bottom (Stange, 2007)

\section{Riparian buffer zones}

A riparian buffer zone is typically represented as a vegetated area between a water body and/or channel that extends from the bank to the developed area (Figure 2- 5) and is split into three zones. Zone 1 begins at the streams edge and extends for 15 to 25 feet with mainly deep rooting plants and trees that provide bank stabilization. Zone 2 starts after zone 1 and can extend for several hundred feet with vegetation of deep rooting shrubs and slow growing trees that provide removal of sediment and nutrients through plant interaction. Zone 3 starts at the end of zone 2 and mainly has grass and herbaceous plants to serve as a protection area for the zone 2 and zone 1 (Aslan, 2009). The zones might not be well-defined in all cases and could possibly be intermixed depending on the riparian buffer that is present. The riparian buffer areas may be regulated by city/state/federal entities for what size is required. The buffer zone is typically made of all native soils with native plants, trees, and shrubs. The buffer zone also is free of 
infrastructure. As stormwater moves from the developed areas through the buffer zones, plants slow down and help to transpire the water and the soils allow the stormwater to infiltrate (zone 1 and zone 2). Through this infiltration and reduction in velocity, suspended solids and nutrients are reduced. The buffer zone also provides a habitat for wildlife and typically spreads out concentrated stormwater discharges over a larger area for a less intense impact on the waterway or water body. Riparian buffers are very beneficial for stormwater treatment but take large amounts of area and typically cannot be implemented after infrastructure has already been built next to a water body or channel. This kind of BMP is best implemented by regional or city planners for new areas.

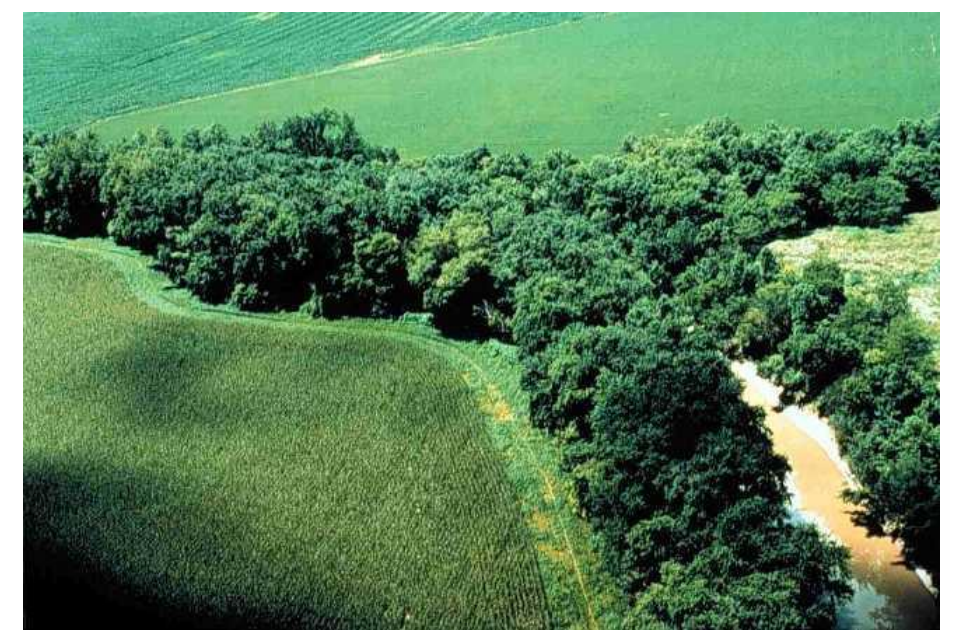

Figure 2- 5: Riparian Buffer Area near Lake Erie (Wikipedia, 2005) 


\section{Retention areas}

Retention areas are characterized by any area that receives water and does not drain past a specified water level (Figure 2- 6). Retention areas may be natural or manmade. Typically the retention areas are natural with some type of man-made outlet to help pond water. The outlet is made of concrete or large boulder-sized stones. The retention area has good characteristics for settling solids, but may not have much treatment of nutrients due to minimal plant growth. Some nutrient removal may be accomplished by biological activity in the lower stratum of the water column near the sediment/water interface. Also, some aquatic life may be able to live in this environment which would also help with nutrient removal. One problem that is commonly occurs is the lack of storage for water. All of the stormwater cannot be detained typically and many detention areas start to drain after the storm event starts. Since this is the case, not much treatment can be attained.

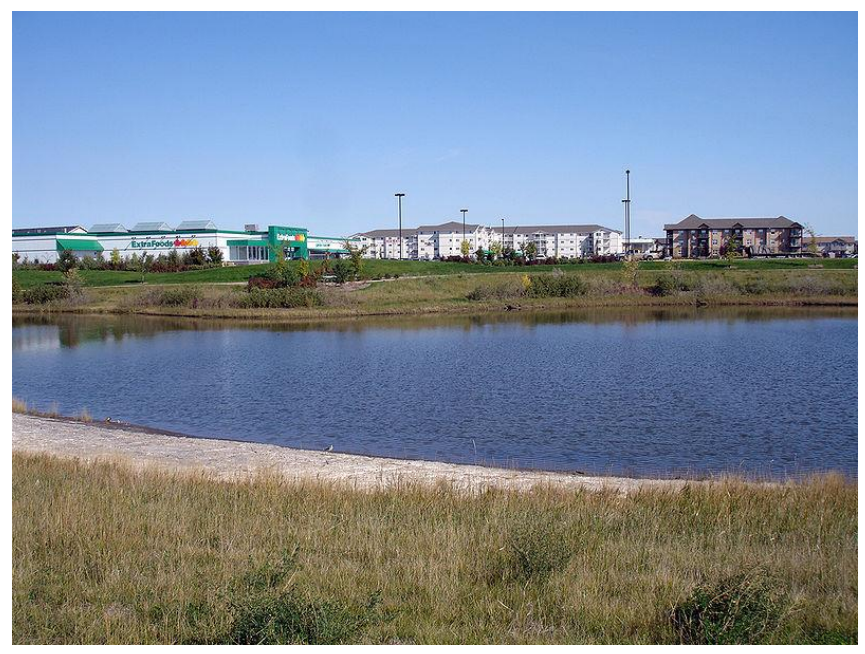

Figure 2- 6: Retention Pond Near a Developed Area (Wikipedia, 2007) 


\section{Detention Areas}

Detention area is a general term for many of the types of BMPs discussed already, but also includes underground storage tanks. A detention area holds stormwater for a specified amount of time and then drains completely after the storm event (Figure 2- 7). Underground storage tanks may be made out of many different materials such as concrete, HDPE, PVC, or other common construction materials. These tanks can also be in many different sizes, configurations, or styles. One type would be a storage tank under a porous pavement to catch the runoff water and then allow it to drain slowly through a pipe. Another type is a storage system under a street or parking lot made of many large diameter connected pipe segments. The style and type chosen are dependent on cost and area available at the chosen site. These types of BMPs are not very good at treating stormwater because they offer no nutrient removal but are good at slowing stormwater to the receiving stream.

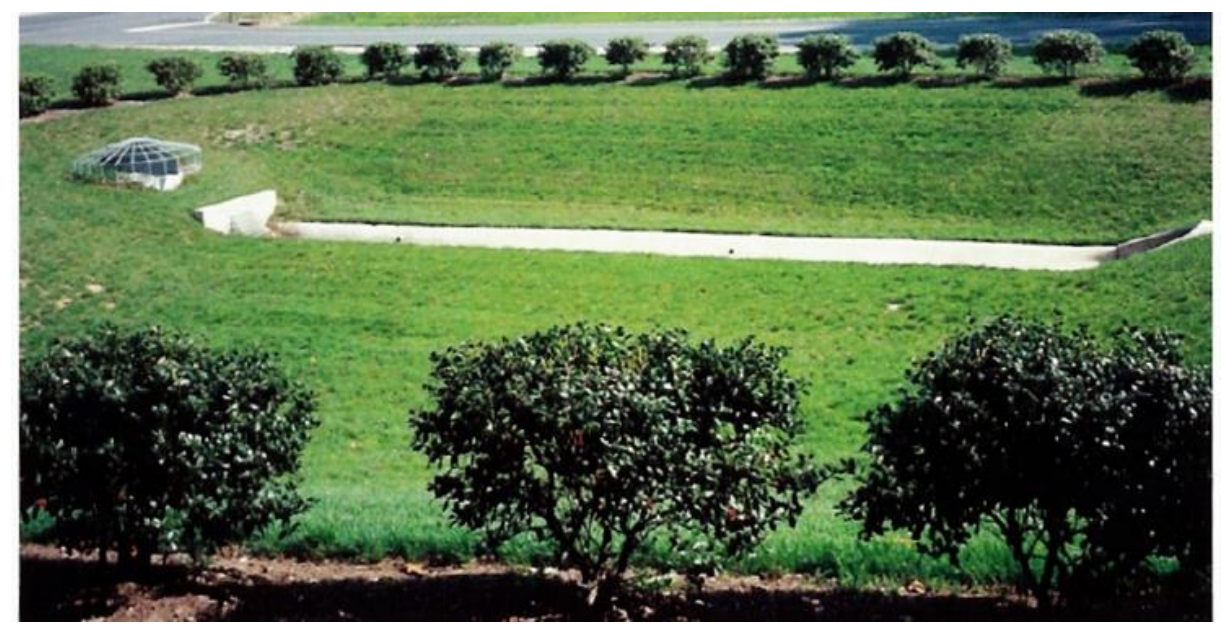

Figure 2- 7: Typical Residential or Small Community Detention Area (Wikipedia, 2006a) 


\section{Wetlands}

Wetlands are characterized by low lying depressions in the land that have a water level year round (Figure 2- 8). To be named a wetland, the area must support a certain type of plant species, soil characteristics, and hydrology characteristics Wetlands allow suspended solids to be reduced along with also reducing nutrients in the stormwater (Das, 2012). Wetlands also slow water being released into the stream which reduces the erosion experienced by the stream and the influx in flow. They are one of the best treatment types that can be used when dealing with stormwater. A downside to the wetland is the large amount of area that it takes to create one with a useful treatment capacity. This is typically due to the slow flow through the wetlands. Although this is an issue, if possible it is always best to send water to a wetland before releasing to a stream because of the better water quality attainment.

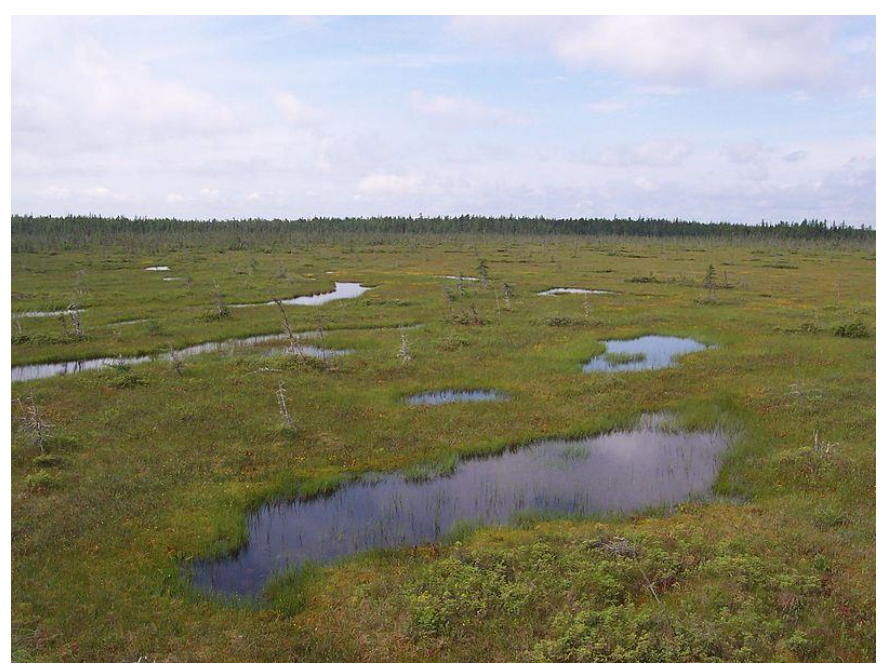

Figure 2- 8: Wetland in Frontenac National Park (Wikipedia, 2008) 


\subsubsection{Bioretention Cells}

A bioretention cell would be best used in a situation when there is not enough land to sustain a wetland or in areas where wetlands are not possible to construct. The bioretention cell can be used in almost any area because of the variable sizes for which it can be designed; it can fit into the corner of a yard or be as large as a field. Typically, bioretention cells are sized to receive multiple stormwater runoff inputs coming from a house or building and are planted with the builder's choice of vegetation.

The bioretention cell is set in place to help improve the treatment of the stormwater and also the infiltration of the water into the soil profile (Clark et al., 2008). In some areas in the United States, infiltration rates are low due to clayey soils. The clayey soils have low infiltration rates because of their tight locking nature. Clays, when viewed under a microscope, have a sheet like appearance and lay on top of one another. This "locking" action does not allow water to penetrate into the substrate very rapidly like a sand would. The bioretention cell uses a specified mix that is predominantly sand. This mixture helps to move the water deep into the bioretention cell and allow it to interact with more surface area of the native soils.

The bioretention cell is characterized by a small to medium pit being dug into a native soil and then new soil media being placed within the cell (Figure 2-9). This pit should be located at the drainage outlet of the area. A perforated drain is placed at the bottom and enough clean gravel sized rock is placed around the pipe to cover it completely. The gravel is then overlain by smaller stones and then some type of fine sand. This lower layer helps to adequately drain the profile without letting excess fine material get into the perforated pipe. Over the fine sand, the bioretention soil mix is 
placed at a depth of roughly 24 to 36 inches. This depth varies based on the site's soil conditions. The bioretention soil mix is made with sand, mulch, compost, topsoil, and other additives that may be dictated by the designer. The sand helps to improve infiltration while the mulch, compost, and topsoil provide plants with essential nutrients to grow and be healthy. Small amounts of clay and silt may also be added to promote attenuation of pollutants during infiltration (Davis et al., 2001). The largest component of the soil mix is the sand. In Maryland the bioretention soil mix is typically made of 3565\% sand, 30-55\% silt, and 10-25\% clay (Environmental Protection Agency, 2009). In Missouri the Maryland recommendations were adapted to use $60 \%$ sand by volume with less than $10 \%$ of the entire soil mix containing clay (District, 2012). The rest of the mix may be a combination of mulch, compost, topsoil, or other additives. Sand is very readily used in these mixes because of its high infiltration rates. The other additives have slower infiltration rates and do not typically make up the majority of the mix. 


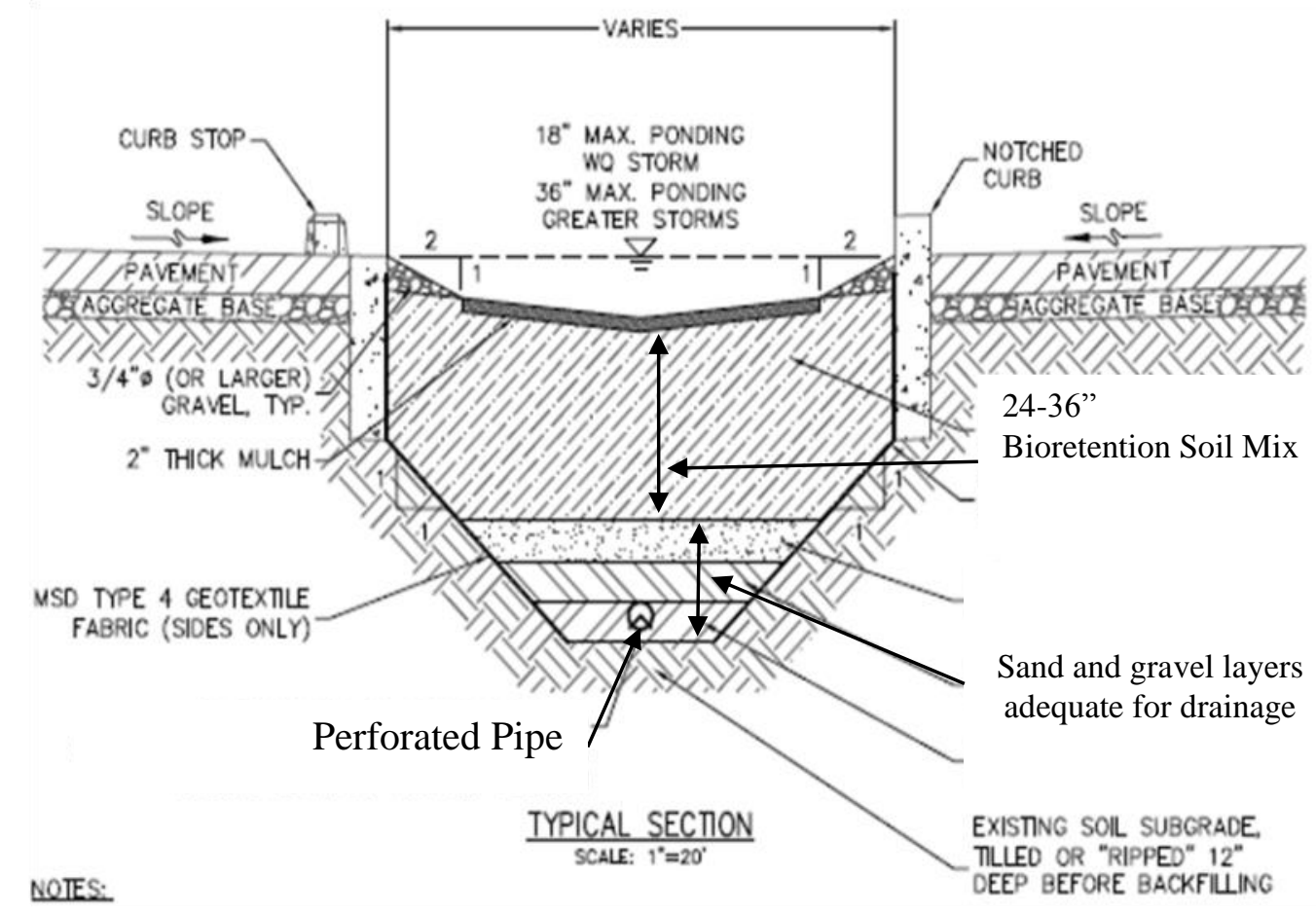

Figure 2- 9: Typical bioretention cross section from St. Louis MSD (St. Louis Metropolitan Sewer District, 2010)

A bioretention cell may also have plantings to achieve two goals, treatment of stormwater and pleasing aesthetics. When plants are added they help to remove nutrients from the water through root action and to transpire water. Plants need essential nutrients to stay alive such as phosphorous $(\mathrm{P})$, nitrogen $(\mathrm{N})$, and potassium $(\mathrm{K})$. The mulch and compost supply some nutrients to the plant in the bioretention soil mix but mainly it is supplied by the incoming stormwater. The incoming stormwater may have high amount of $\mathrm{N}, \mathrm{P}$, or $\mathrm{K}$ and may not all be treated by the plants, but it is more than when there are no plants within the bioretention cell. The plantings also offer a pleasing aesthetic quality for people in the area. The landscapers may choose plants that are native or non-native. Typically native species are chosen because they have the best chance to live in the climatic range. Annual flowering plants may also be chosen to give bright colors to the 
bioretention cell but would not offer as much treatment as an established perennial due to the lacking root structure and relatively short life span of the in-place plant. In Missouri selection of native perennial species is always preferred over a non-native because of the native's ability to thrive in drought and also the depth of the root (District, 2012).

Choosing a native species provides the best chance of reducing the need to replace plants in the bioretention cell over time.

\subsection{Drinking Water Treatment Residual Addition to Soils}

Drinking water treatment residual (DWTR) addition to soils is relatively new and unexplored for applications in large scale operations. DWTRs traditionally have two "disposal" paths: landfill or land application. Because many DWTRs have already been cleared for land application, it would be relatively easy to acquire and use DWTRs as an addition to bioretention soil mixes. Additionally, the $\mathrm{Ca}, \mathrm{Fe}$, and $\mathrm{Al}$ coagulants in their product form can uptake phosphorous. After the treatment process the DWTRs still have some affinity for phosphorous and may be dependent on the dosing used, on the type of solids in the treatment process, and on additional additives used during the treatment process.

\subsubsection{Typical Drinking Water Treatment Process}

Drinking water treatment plants (DWTPs) draw water into their process from a groundwater or surface water source (Figure 2-10). Surface water may include rivers, lakes, or the ocean/sea. DWTPs are designed differently for each situation and may vary in what solids are created based on source water characteristics. After the water enters the DWTP, it goes through a rapid mixer which introduces a highly charged coagulant. These coagulants typically come in the form of a metal-polymer blend. The most popular blends 
are calcium (as lime), Alum, Aluminum Sulfate, Polyaluminum Chloride, Ferric Chloride and Ferric Sulfate (Edzwald, 1993). After the rapid mix step, the water is sent to a flocculation chamber to allow flocs to form. After floc formation, a clarification basin is used which allows the large flocs to settle to the bottom of the clarifier. After these solids (residuals) settle, they are pumped to a dewatering area, lagoon, or incinerator. After the dewatering, lagoon, or incinerator, the DWTR may be land applied or sent to the landfill. Depending on the situation at the DWTP, any one or a combination of dewatering, lagoons, or incineration options may be used to handle the drinking water treatment residuals. The process may vary between DWTPs due to the goals or treatment setup. The fate (land application or landfill) of the DWTRs is at the discretion of the local and state regulatory agencies and surrounding soil conditions (land application possibilities).

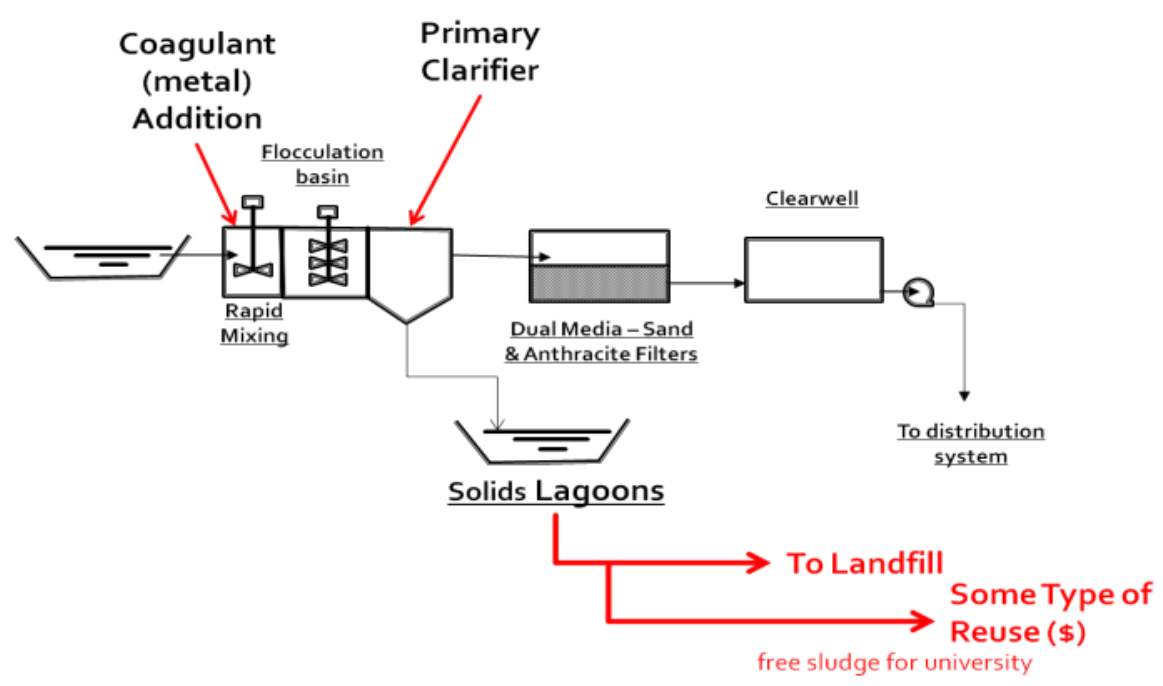

Figure 2- 10: Basic Layout of a Drinking Water Treatment Plant 


\subsubsection{Types of Drinking Water Treatment Coagulants Used}

Water treatment residuals typically are made of highly charged metals. $\mathrm{Ca}, \mathrm{Fe}$, and $\mathrm{Al}$ mixtures are used to coagulate the particulate matter in water. The typical coagulants used are calcium (as lime), Alum (Aluminum Sulfate), Polyaluminum Chloride, Ferric Chloride and Ferric Sulfate (Edzwald, 1993). Coagulation occurs by the highly positively charged metals attracting negatively charged suspended solids. Through this action a floc is formed and the suspended solids can be settled as they are heavier than the upward buoyant force. The particles are attracted to the coagulant through three mechanisms: electrostatic forces, Van Der Waals forces, and Brownian motion. To assess the effectiveness of the coagulant, a zeta potential machine can be used to measure the electrical charge in the water (Qasim et al., 2002).

\section{Attraction Mechanisms for Coagulants and Suspended Solids}

Electrostatic forces are driven by differences in charge and distance from the opposing or similar charge. If oppositely charged particles are close to one another they will be attracted. If two particles of the same charge are close to one another they will repel. The repelling action can be overcome when there is a highly charged particle of the opposite charge (i.e., metal attracting suspended solids). The electrostatic forces typically drive how well the suspended solids will adhere to the coagulant and therefore the overall stability of the particle. Van Der Waals forces are described by the attraction of the two particles regardless of the distance. Because this attraction may be very small, it does not typically predominate unless the particles come in contact with one another. Brownian motion helps to facilitate the electrostatic forces and Van Der Waals forces. Brownian motion is described by random motion of a molecule. Through this random 
motion, collisions occur which might cause particles to attract one another (Qasim et al., 2002).

\section{Zeta Potential}

Zeta potential can be used to evaluate how well a coagulant is performing and if the coagulant dosing is optimal. Zeta potential measures the charge on the shell of the particle in millivolts. The particles center, referred to as a "colloid", is made of highly charged negative or positive particles. The surface charge of the colloid attracts ions of the opposite charge which are tightly bound to the colloid surface. The diffuse layer is outside of the stern layer and is not as strongly attracted to the colloid. The diffuse layer has a shear plane as some of the diffuse layer may not act with the particle. This shear surface is measured through zeta potential (Qasim et al., 2002). A low zeta potential, zero to positive or negative $30 \mathrm{mV}$, represents a stable particle and diffuse layer. As the number becomes larger, positive or negative, the diffuse layer and the particle are unstable. If a large zeta potential is found, it could mean the process is not being optimally dosed with coagulant and particles will remain in suspension. 


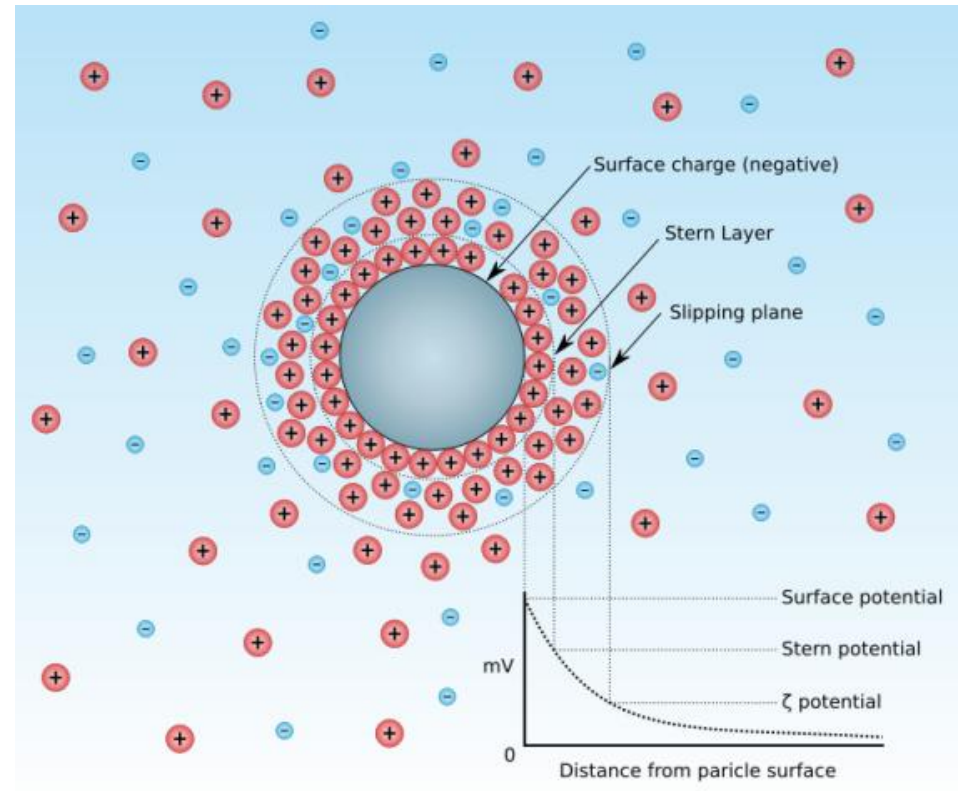

Figure 2- 11: Graphical Representation of a Colloid with a Zeta Potential (Wikipedia, 2012)

\subsubsection{Drinking Water Treatment Coagulant Chemical Formulas}

Drinking water treatment coagulants vary from treatment facility to treatment facility and may be used in combination with other additives to treat a wide range of constituents in the water. Since this is the case, the DWTP residuals must be characterized on a case-by-case basis by talking to the operators and designers of the DWTP. In this subchapter, basic formulations of coagulants used in the research will be discussed. The basic reaction (Equation 1) which describes in the metal-phosphorous precipitation process has the negatively charged orthophosphate combine with a positively charged metal to form an insoluble solid plus excess hydrogen ions in the following (Aguilar et al., 2002): There are a number of secondary reactions that go along with this process. It is generally assumed that the phosphorous is in the form of orthophosphate is removed by precipitation of phosphate with the metal ion(Aguilar et al., 2002) . 


$$
\mathrm{Me}^{3+}+\mathrm{H}_{\mathrm{n}} \mathrm{PO}_{4}^{\mathrm{n}-3} \leftrightarrow \mathrm{MePO}_{4}+\mathrm{nH}^{+}
$$

Me: a charged metal particle in solution (i.e. coagulant)

Water Treatment Residuals Generalized Chemical Formulas

The reactions for calcium, aluminum sulfate, and ferric chloride are adapted from Ebeling et al. (2003), Zhou et al. (2012), and Yang et al. (2006).

Calcium (as Lime) from the precipitation process

Interaction of un-reacted calcium: Ca with orthophosphate:

$$
5 \mathrm{Ca}+3 \mathrm{PO}_{4}+\mathrm{OH} \Leftrightarrow \mathrm{Ca}_{5}\left(\mathrm{PO}_{3}\right)_{3}(\mathrm{OH})
$$

Aluminum Sulfate

Interaction of un-reacted aluminum sulfate (alum): $\mathrm{Al}_{2}\left(\left(\mathrm{SO}_{4}\right)_{3} \cdot 18 \mathrm{H}_{2} \mathrm{O}\right)$ with bicarbonate (influent raw water):

$$
\mathrm{Al}_{2}\left(\mathrm{SO}_{4}\right)_{3} \cdot 18 \mathrm{H}_{2} \mathrm{O}+3 \mathrm{Ca}\left(\mathrm{HCO}_{3}\right)_{2} \Leftrightarrow\left(2 \mathrm{Al}(\mathrm{OH})_{3}\right)+3 \mathrm{CaSO}_{4}+6 \mathrm{CO}_{2}+18 \mathrm{H}_{2} \mathrm{O}
$$

Interaction of the residual created by the treatment process with orthophosphate:

$$
2 \mathrm{AlOH}+\mathrm{H}_{2} \mathrm{PO}_{4} \Leftrightarrow \mathrm{Al}_{2} \mathrm{HPO}_{4}+\mathrm{H}_{2} \mathrm{O}+\mathrm{OH}
$$




\section{Ferric Chloride}

Interaction of un-reacted ferric chloride: $\mathrm{FeCl} 3$ with bicarbonate (influent raw water):

$$
2 \mathrm{FeCl}_{3} \cdot 6 \mathrm{H}_{2} \mathrm{O}+3 \mathrm{Ca}\left(\mathrm{HCO}_{3}\right)_{2} \Leftrightarrow 2 \mathrm{Fe}(\mathrm{OH})_{3}+3 \mathrm{CaCl}_{2}+6 \mathrm{CO}_{2}+12 \mathrm{H}_{2} \mathrm{O}
$$

Interaction of the residual created by the treatment process with orthophosphate:

$$
\mathrm{FeOH}+\mathrm{H}_{2} \mathrm{PO}_{4} \Leftrightarrow \mathrm{FeH}_{2} \mathrm{PO}_{4}+\mathrm{OH}
$$

\subsubsection{Drinking Water Treatment Residual Addition to Bioretention Soil Mixes}

\section{Introduction}

Orthophosphate $\left(\mathrm{PO}_{4}\right)$ in runoff water can be high in certain areas where there is livestock, fertilizer addition, high sediment loads or other phosphorous producing processes. This $\mathrm{PO}_{4}$ can be detrimental to waters that are $\mathrm{PO}_{4}$ limited because it promotes algae growth and jumpstarts the eutrophication process. It was found that $\mathrm{PO}_{4}$ can be sorbed by drinking water treatment residuals (Agyin-Birikorang et al., 2009). This is possible through the opposite charge of the coagulant (positive) and the $\mathrm{PO}_{4}$ (negative). Similar studies have been done using typical coagulants from a drinking water treatment process to mainly sequester phosphorous from agricultural runoff (Agyin-Birikorang et al., 2007; Agyin-Birikorang et al., 2009; Fenton et al., 2011; Novak et al., 2004). 


\section{Drinking Water Treatment Plant Coagulant Phosphorous Uptake}

Aguilar et al. (2002) evaluated non-reacted (mainly virgin coagulants rather than residuals) ferric sulfate, aluminum sulfate, and polyaluminum chloride. The study found that $\mathrm{PO}_{4}$ reduction in all three types of studied coagulants reduced $\mathrm{PO}_{4}$ by greater than 99 percent (Aguilar et al., 2002).

Ebeling et al. (2003) used alum and ferric chloride in an aquaculture study to determine at what dose and conditions the coagulants removed total suspended solids and phosphorous optimally. At the optimum dosage ( $90 \mathrm{mg} / \mathrm{L})$, alum and ferric chloride removed $89 \%$ and $93 \%$ orthophosphate respectively. Optimum dosage for TSS removal was found to be $60 \mathrm{mg} / \mathrm{L}$ for both coagulants. The flocculation and mixing speeds played minor roles in the removal efficiencies for both orthophosphate and turbidity (Ebeling et al., 2003) .

Fenton et al. (2011) used a similar approach of laboratory testing of coagulants and looked specifically at bottom ash, alum, iron chloride tetrahydride, and calcium hydroxide in a dairy-soiled water (DSW) operation. DSW is described as water from concentrated areas that becomes contaminated by feces, chemical fertilizers, and parlour washing. DSW can be land applied at a max rate of 50,000 L/ha in any 48-day period. The amendments were ranked in order of feasibility (Table 2-2) with alum (72\% phosphorous reduction) as the best choice followed by iron chloride tetrahydride (90\% phosphorous reduction), bottom ash (45\% phosphorous reduction) and calcium hydroxide (83\% phosphorous reduction). Feasibility was based on cost, potential for adverse effects, public perception, and performance (Fenton et al., 2011). 
Table 2- 2: Feasibility of Amendments; Adapted from Fenton et al. (2011)

\begin{tabular}{|c|c|c|c|c|c|}
\hline$\underset{t}{\text { Amendmen }}$ & $\begin{array}{l}\text { Feasibilit } \\
\text { y Score }\end{array}$ & $\begin{array}{c}\text { Addition } \\
\text { Rate } \\
\left(\mathrm{kg} / \mathrm{m}^{3}\right)\end{array}$ & $\begin{array}{l}\text { Total Cost } \\
\left(\text { Euro/m } \text { m }^{3}\right)\end{array}$ & $\begin{array}{l}\text { Reduction } \\
\text { of } \\
\text { Phosphoro } \\
\text { us }(\%)\end{array}$ & Discussion \\
\hline Alum & 1 & 3 & 1.92 & 72 & $\begin{array}{l}\text { Cheap and widely used } \\
\text { in water treatment. } \\
\text { Negative public } \\
\text { perception about land- } \\
\text { spreading Al may be } \\
\text { problematic. Potential } \\
\text { elevated release of } \\
\text { greenhouse gases. }\end{array}$ \\
\hline $\begin{array}{c}\mathrm{FeCl}_{2} * 4 \mathrm{H}_{2} \\
\mathrm{O}\left(\mathrm{FeCl}_{3}\right)\end{array}$ & 2 & 10 & 3.55 & 89 & $\begin{array}{l}\text { Potential elevated } \\
\text { release of greenhouse } \\
\text { gases. Negative public } \\
\text { perception about land } \\
\text { spreading Fe may be } \\
\text { problematic }\end{array}$ \\
\hline $\begin{array}{l}\text { Bottom } \\
\text { Ash }\end{array}$ & 3 & 67 & 1.55 & 45 & $\begin{array}{l}\text { Contains heavy metals. } \\
\text { Settles quickly so } \\
\text { thorough mixing may be } \\
\text { difficult }\end{array}$ \\
\hline Lime & 4 & 67 & 20.31 & 83 & $\begin{array}{l}\text { Available on farms, no } \\
\text { danger or metal losses to } \\
\text { the environment, good } \\
\text { public perception, and } \\
\text { can help with lime } \\
\text { requirements. } \\
\text { Prohibitive cost at } \\
\text { application rates } \\
\text { required. }\end{array}$ \\
\hline
\end{tabular}




\section{Drinking Water Treatment Plant Residuals (DWTRs) Phosphorous Uptake}

Agyin-Birikorang et al. (2009) used reacted aluminum and iron based WTRs in their study of $\mathrm{PO}_{4}$ sorption. The study was based in Florida where there is a high amount of phosphorous present in the soil and it is also the limiting nutrient. Agyin-Birikorang et al. (2009) found up to $10,000 \mathrm{mg}$ Phosphorous/kg solid could be applied and most of the studied WTRs would sorb all of the phosphorous. The study also focused on soil amendments with the WTR. After amending an Immokalee fine sand with aluminum based WTR (rate of 56 metric tons/ha) it was found that an approximately $88 \%$ reduction in runoff + lechate dissolved phosphorous was found as compared with the control plot without the WTR amendment. It was further found that phosphorous from triple superphosphate fertilizer was reduced by Ca-WTR (76.5\%), Fe-WTR (97.5\%), and AlWTR (99\%) at a WTR application of 10 tons/acre. Overall it was noted that application of WTRs to poorly phosphorous sorbing soils increases the phosphorous capacity of the soil and reduces off-site runoff of phosphorous. (Agyin-Birikorang et al., 2009)

Novak et al. (2004) investigated addition of alum based WTRs to an Autryville soil and Norfolk soil in North and South Carolina. The Al-WTR was collected twice from a water treatment utility ten months apart and mixed into the two soils at a rate (tons/ha) of 0 (0\% WTR), 50 (2.5\% WTR), 100 (5.0\% WTR), 175 (7.5\% WTR), and 225 (10\% WTR). In the Autryville soil (10\% WTR) sorption rates of phosphorous for samples 1 and 2 were found to be 8.5 and $6.9 \mathrm{mg}$ P/g WTR, respectively. The Norfolk soils had a phosphorous sorption (10\% WTR) of 8.3 and $5.8 \mathrm{mg} \mathrm{P/g} \mathrm{WTR.} \mathrm{In} \mathrm{both} \mathrm{cases,} \mathrm{the}$ second sample from the water treatment utility showed a lower phosphorous sorption. The difference may have been due to slightly different additions of alum at the water 
treatment plant or a slightly different operational strategy between the two samples. Novak and Watts (2004) go on to state application of alum-based WTRs to manuretreated soils could serve as a new chemical-based BMP and adding alum-based WTRs to soils can increase phosphorous sorption, therefore reducing offsite phosphorous movement (Novak et al., 2004).

Haustein et al. (2000) studied the phosphorous interaction with two waste products: a DWTR and HiClay Alumina (HCA). Both the WTR and HCA contained aluminum. The HCA is obtained as a byproduct of the commercial alum production. The DWTR and HCA were applied on separate plots of land at a rate of 0, 2.2, 9.0, and 18 $\mathrm{Mg} /$ hectare. The WTR was also applied at $1.1 \mathrm{Mg} /$ hectare because the preliminary data suggested it would perform better than the HCA. The aluminum content of the WTR and HCA were $46.7 \mathrm{~g}$ per $\mathrm{kg}$ and $15.9 \mathrm{~g}$ per $\mathrm{kg}$, respectively. It was shown that the dissolved phosphorous in the storm water was reduced the most by HCA on day 1 (difference of $0.2 \mathrm{mg} / \mathrm{L})$ but at the 1 month and 4 month periods, the WTR performed better $(0.4 \mathrm{mg} / \mathrm{L}$ at 1 month and $0.5 \mathrm{mg} / \mathrm{L}$ at 4 months). It was concluded that aluminum based materials can reduce phosphorous in the runoff and higher aluminum contents can lead to more phosphorous uptake. Overall, the phosphorous adsorption for the WTR was 20 times higher than the HCA because it contained more clay and almost three times the aluminum (Haustein et al., 2000).

Agyin-Birikorang et al. (2007) used artificial aging techniques to check the stability of phosphorous over a 7.5 year period for the field-aged plots and 4.5 years for the lab-aged residuals. The WTR was mixed in an agricultural field in Michigan as well with soil in the lab. Artificial and natural aging techniques were employed. After lab- 
aging the WTR plus soil, the results were checked against the field-aged samples. It was found that compared to the no-WTR (control) samples, the lab-aged WTR and the fieldaged WTR reduced liable phosphorous by over $70 \%$. It was also shown that the WTR will immobilize phosphorous over long periods of time over a $\mathrm{pH}$ range from 3 to 7 according to laboratory data. (Agyin-Birikorang et al., 2007)

Phosphorous and Metal Interaction with Respect to $\mathrm{pH}$

Razali et al. (2007) studied Al-WTR exclusively over a range of pH values and with different types of phosphate. They found a wide range of phosphorous species can be removed by the Al-WTR with adding a relatively low mass of the WTR. The highest sorption capacity was had by orthophosphate $\left(\mathrm{KH}_{2} \mathrm{PO}_{4}\right)$, followed by polyphosphate $\left(\left(\mathrm{NaPO}_{3}\right)_{6}\right)$, and finally organic phosphate $\left(\mathrm{C}_{10} \mathrm{H}_{14} \mathrm{~N}_{5} \mathrm{O}_{7} \mathrm{PH}_{2} \mathrm{O}\right)$. The Al-WTR was able to remove $>80 \%$ of all phosphorous species in 30 days and at the 60 day test period did not yet reach phosphorous saturation. With these findings it is said that Al-WTR is a good reuse option for units such as constructed wetlands and can also reduce the financial burden of disposal to the water treatment plant (Razali et al., 2007).

\section{Other media and the Interaction with Phosphorous}

Peleka et al. (2008) studied laboratory synthesized goethite $(\mathrm{FeO}(\mathrm{OH}))$, commercial alumina $\left(\mathrm{Al}_{2} \mathrm{O}_{3}\right)$, and commercial hydrotalcite $\left(\left(\mathrm{Mg}_{6} \mathrm{Al}_{2}\left(\mathrm{CO}_{3}\right)(\mathrm{OH})_{16} \cdot 4\left(\mathrm{H}_{2} \mathrm{O}\right)\right)\right.$. At 25 degrees Celsius, phosphorous sorption was found to be (units of $\mathrm{mg}$ phosphorous per gram of media) $244.58 \mathrm{mg} / \mathrm{g}$ for calcined hydrotalcite (created at 500 degress Celsius), $192.9 \mathrm{mg} / \mathrm{g}$ for calcined hydrotalcite (created at 400 degrees Celsius), $144 \mathrm{mg} / \mathrm{g}$ for goethite, $60 \mathrm{mg} / \mathrm{g}$ for uncalcined hydrotalcite, and 34.57 
$\mathrm{mg} / \mathrm{g}$ for aluminum oxide. It was also noted that the adsorption kinetics obeyed a pseudosecond-order kinetic model(Peleka et al., 2008).

Ma et al. (2010) evaluated zeolite and engineered media (EM) for phosphorous uptake using collected on-site stormwater. The zeolite used was a natural or synthetically made aluminosilicate mineral, and EM was made from perlite and alumina. It was found that the EM reduces phosphorous by 50 percent for 1000 treated bed volumes while the zeolite only lasted for a couple of bed volumes before the zeolite could no longer sorb phosphorous. In some of the testing, Ma et al. (2010) found the EM to remove greater than 70 percent of the influent total phosphorous. Overall, it was found that EM is a promising material to use to uptake stormwater phosphorous (Ma et al., 2010). 


\subsection{METHODS}

For this research, two distinct approaches were taken to accomplish the research goals: (1) determining the P sorption capacity of the Drinking Water Treatment Residuals (DWTRs) and (2) determining the ability of a DWTR-soil mix to inhibit phosphorous (P) leaching from the bioretention cell. Equilibrium testing was used to test the DWTRs sorption capacity which entailed the addition of DWTRs to prescribed amounts of a phosphorous solution and then allowing the solution to come to equilibrium (Section 2.1). The second testing performed was creating lab-scale bioretention cells and pumping a stormwater solution into them for a prescribed amount of time to verify the soil mix in the lab created bioretention cell was leaching $\mathrm{P}$ and that the addition of DWTRs to the soil mix inhibited this leaching.

\subsection{Drinking Water Treatment Residual Capacity Testing}

\subsubsection{Introduction}

Some of the previous DWTR applications include amending fields where cattle's grazing was present or amending the edge or portions of the field. There was not much research in the area of taking a DWTR and applying to a bioretention soil mix. The main goal of the capacity testing is to establish a protocol for testing what kind of overall performance locally sourced DWTRs can offer.

\subsubsection{Materials}

Drinking water treatment plants use the same basic treatment train (Figure 2- 10); receive a source water, addition of coagulant and primary settling, and disinfection. The sludge for testing is taken from the primary settling chamber or primary settling sludge 
drying lagoon. Some processes enhance drying of the sludge by mixing in a polymer and if the sludge is intended for land application, it would most likely have this drying aid already in it. Sampling is typically easier from the sludge drying lagoon which has sludge of different ages as treatment plants only empty their lagoons as needed. The sludge age is dependent on how often the sludge is transported off site and how often the sludge is supplied from the settling tank.

\subsubsection{Method}

For the equilibrium experiments the method from Peleka and Deliyanni (2008) was used and modified slightly. A constant volume of 100mL phosphate solution was mixed with $100 \mathrm{mg}$ of the dried WTR (dried at 50 degrees $\mathrm{C}$ for 24 hours) in a $125 \mathrm{~mL}$ Erlenmeyer (conical) flask. The phosphorous solution was made using potassium dihydrogen phosphate (KH2PO4, mixing for at least 30 minutes to ensure homogenous solution) then phosphate was measured using a Dionex 3000 Ion Chromatograph following the EPA 300.1 method (US EPA, 1999). The concentrations of phosphate in solution used were: $5 \mathrm{mg} / \mathrm{L}, 10 \mathrm{mg} / \mathrm{L}, 25 \mathrm{mg} / \mathrm{L}, 50 \mathrm{mg} / \mathrm{L}, 100 \mathrm{mg} / \mathrm{L}$, and $200 \mathrm{mg} / \mathrm{L}$. The conical flask with the WTR-Phosphate solution was then put on a shaker machine for 24 hours at a maximum shaking rate of $200 \mathrm{rpm}$ with a constant ambient room temperature. After 24 hours, the WTR-Phosphate solution was filtered using a vacuum bottle fitted with a $45 \mathrm{~nm}$ pore size membrane filter. The concentration of phosphorous in the filtrate was measured again using the Dionex 3000. 


\subsection{Lab Scale Soil Column Testing}

\subsubsection{Introduction}

The lab scale soil column testing is used to corroborate data from other sources that showed bioretention cells were not treating influent phosphorous $(\mathrm{P})$ and in some cases actually increasing the effluent P (Dietz et al., 2005). The experiment was designed to only test one type of bioretention mix and hold constant the amount of $\mathrm{P}$ in the influent at $0.5 \mathrm{mg} / \mathrm{L}$ for the $100 \%$ bioretention soil mix $(\mathrm{BSM})$ and $6.2 \mathrm{mg} / \mathrm{L}$ for the BSM-DWTR experiments. Since these were constant, it was possible to test how much effluent $\mathrm{P}$ was present over many iterations. After baseline testing was completed (100\% bioretention mix), the testing moved to the addition of $\mathrm{Ca}, \mathrm{Fe}$, and Al DWTRs. The DWTRs were mixed into cleaned cells at volumes of 5\%,10\%, and 20\%. During the DWTR testing, the amount of influent phosphorous was also increased to $6.2 \mathrm{mg} / \mathrm{L}$ to overload the DWTR with phosphorus. It was found that only the Ca became overloaded with phosphorous at all percentages $(5 \%, 10 \%$, and $20 \%)$.

\subsubsection{Materials}

\section{Lab-scale Bioretention Cell}

To test how well phosphorous was sorbed within a bioretention cell, a lab-scale version was made. The lab-scale version (Figure 3-1) used a 2.5 inch diameter PVC pipe by 7 inches long with a square Plexiglass $@$ base that is slightly larger than the PVC pipe. The top was left open for tubing from a peristaltic pump that would later pump stormwater into the lab-scale bioretention cell. A ball valve type drain was inserted into 
the PVC pipe close to the base to allow drainage from the cell when testing was taking place and also to allow ease of sampling from the cell.

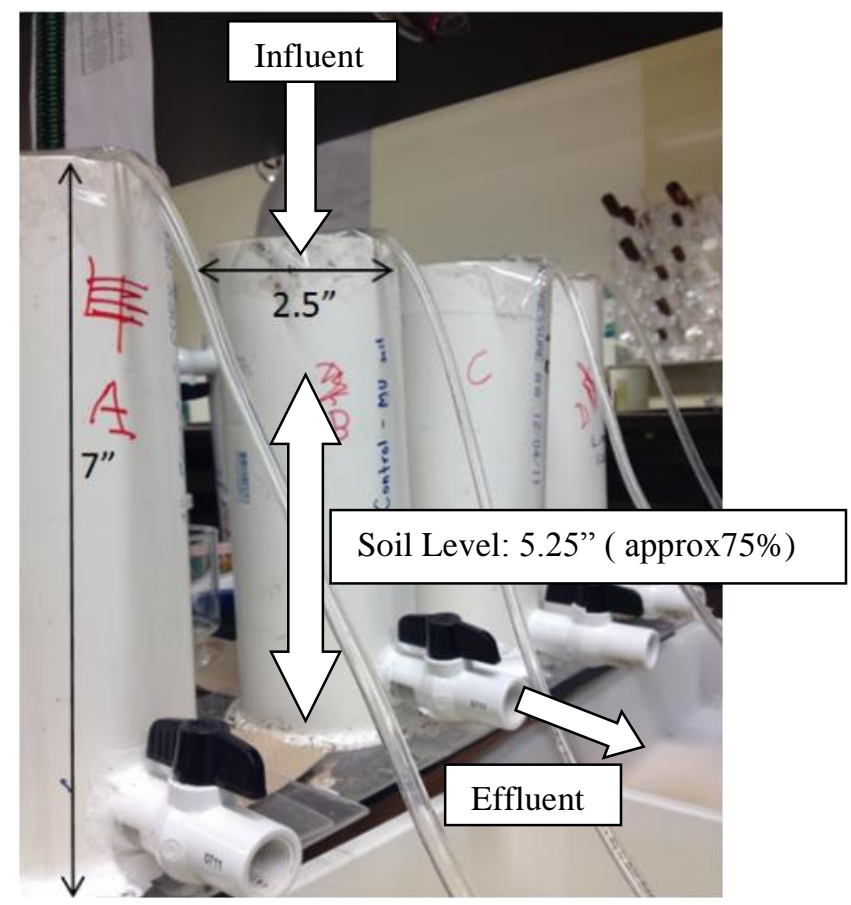

Figure 3- 1 General lab-scale bioretention setup

Bio-retention mix

The bioretention mix used in the lab-scale cell was obtained from St. Louis Compost in St. Louis Missouri (StL Compost, http://www.stlcompost.com/). The mix was used primarily because it is a popular bioretention mix that is used by installers of St. Louis rain gardens. StL Compost also regularly sends sample batches of their mix to an independent lab for testing to make sure it is up to St. Louis Metropolitan Sewer District (StLMSD) specifications. The bioretention mix set forth by StLMSD for use in bioretention cells was decided by reviewing what other places in the United States were using. After review, MSD found that $60 \%$ or greater sand and less than $10 \%$ clay by volume was a common formula for the mix. The soil should also be free of stones, 
stumps, roots, or other woody material over 1 inch in diameter. The saturated hydraulic conductivity is required to be 1.0 feet per day or 0.5 inches per hour (District, 2012). The main goal of the mix is to slow down storm water, remove some pollutants from the first flush, and provide a soil that drains well.

\section{Addition of DWTRs}

Each of the Ca-, Fe-, and Al-DWTRs were dried in an oven at 50 degrees Celsius for 24 hours. The dry DWTR was then added to the bioretention mix at a prescribed volume ratio of 5,10 , or $20 \%$ () to test performance of the residuals. The addition of the DWTR follows a similar strategy of application as Novak et al. (2004). The weight at the prescribed volumes was also recorded and is also shown in . The 0\% DWTR testing represents the testing done before the addition of the DWTR where only the bioretention mix was being testing.

Table 3- 1: Bioretention Soil Mix (BSM) and Water Treatment Residual (WTR) Mixing Ratios (by Volume)

\begin{tabular}{|c|c|c|c|c|c|c|}
\hline $\begin{array}{c}\text { Percentage } \\
\text { of } \\
\text { WTR:BSM }\end{array}$ & $\begin{array}{c}\text { WTR } \\
\text { Added } \\
(\mathbf{L})\end{array}$ & $\begin{array}{c}\text { BSM } \\
\text { Added (L) }\end{array}$ & $\begin{array}{c}\text { Total } \\
\text { Volume } \\
(\mathbf{L})\end{array}$ & $\begin{array}{c}\text { Ca- } \\
\text { WTR } \\
(\mathbf{g})\end{array}$ & $\begin{array}{c}\text { Fe- } \\
\text { WTR } \\
(\mathbf{g})\end{array}$ & $\begin{array}{c}\text { Al- } \\
\text { WTR } \\
(\mathbf{g})\end{array}$ \\
\hline $0 \%: 100 \%$ & 0 & 1.75 & 1.75 & 0.0 & 0.0 & 0.0 \\
\hline $5 \%: 95 \%$ & 0.08 & 1.67 & 1.75 & 61.2 & 38.0 & 45.4 \\
\hline $10 \%: 90 \%$ & 0.175 & 1.575 & 1.75 & 122.3 & 76.0 & 90.9 \\
\hline $20 \%: 80 \%$ & 0.35 & 1.4 & 1.75 & 244.7 & 152.0 & 181.7 \\
\hline
\end{tabular}




\section{Synthetic Stormwater}

A synthetic stormwater was created to mimic surface stormwater runoff. The stormwater mix was adapted from Davis et al. (2001) as shown in . The stormwater mix simulates what typical storm constituent levels would be. Based on this recipe, for a storm covering a 1 acre are whose intensity is $1 \mathrm{in} / \mathrm{hr}$ the total storm water runoff volume of $102,802 \mathrm{~L}$ should yield a total P load of $51.4 \mathrm{~g}$.

Table 3- 2: Synthetic Stormwater Recipe

\begin{tabular}{|c|c|c|}
\hline $\begin{array}{c}\text { Water Quality } \\
\text { Parameter }\end{array}$ & $\begin{array}{c}\text { Concentration } \\
\text { mg/L }\end{array}$ & Source \\
\hline COD & 100 & Beef Extract \\
\hline & & Glucose \\
\hline Ammonium-N & 1.4 & $\mathrm{NH}_{4} \mathrm{Cl}$ \\
\hline Nitrate-N & 2.07 & $\mathrm{NaNO}_{3}$ \\
\hline Organic Nitrogen & 3 & Glycine $\left(\mathrm{NH}_{2} \mathrm{CH}_{2} \mathrm{COOH}_{2}\right.$ \\
\hline Phosphorus & 0.5 & Dibasic Sodium Phosphate $\left(\mathrm{Na}_{2} \mathrm{HPO}_{4}\right)$ \\
\hline Copper & 0.1 & Cupric Sulfate $\left(\mathrm{CuSO}_{4}\right)$ \\
\hline Lead & 0.1 & Lead Chloride $\left(\mathrm{PbCl}_{2}\right)$ \\
\hline Zinc & 0.1 & Zinc Chloride $\left(\mathrm{ZnCl}_{2}\right)$ \\
\hline pH & 7 & $\mathrm{HCl}$ or $\mathrm{NaOH}$ \\
\hline
\end{tabular}

Synthetic Stormwater Creation

The synthetic stormwater stock solution was made by filling a $1000 \mathrm{~mL}$

Erlenmeyer flask with $800 \mathrm{~mL}$ of DI water and one magnetic stir bar. The Erlenmeyer flask was then put on a stir table to be mixed. The prescribed amount of chemicals was added to the $800 \mathrm{~mL}$ of DI water to make the specified concentration (). After each chemical was added, the weighing dish was rinsed with water to ensure the entire weighed chemical was in the Erlenmeyer flask. The weighing dishes were discarded after each chemical was weighed to minimize either over or under measurements. After all the chemicals were weighed and added, the Erlenmeyer flask was filled with DI water to the 
$1000 \mathrm{~mL}$ mark and allowed to mix for an additional 30 minutes to ensure a homogenous mixture. While the stock solution was mixing, a large, clean, container was filled with 89 Liters of room temperature tap water. After the 30 minutes of mixing, the stir bar was removed and the concentrated stock solution was added to the 89 Liters of water. The dilute storm water solution was then mixed. The influent peristaltic pump influent hoses were placed within the synthetic stormwater solution as the feed solution for cell test runs.

Synthetic Stormwater for BSM-WTR experiments

The stormwater recipe was changed in the drinking water treatment residual (DWTR) experiments because phosphorous was the only nutrient of concern. The recipe was changed with the increase of phosphorous content from 0.5 to $6.2 \mathrm{mg} / \mathrm{L}$ ().

Table 3- 3: Changes to Stormwater Recipe for the Bioretention Mix plus WTR

\begin{tabular}{|c|c|c|c|}
\hline & $\begin{array}{c}\text { Water Quality } \\
\text { Parameter }\end{array}$ & $\begin{array}{c}\text { Concentration } \\
\text { mg/L }\end{array}$ & Source \\
\hline $100 \%$ BSM Runs & Phosphorus & 0.5 & $\begin{array}{c}\text { Dibasic Sodium } \\
\text { Phosphate }\left(\mathrm{Na}_{2} \mathrm{HPO}_{4}\right)\end{array}$ \\
\hline BSM-WTR Runs & Phosphorus & 6.2 & $\begin{array}{c}\text { Dibasic Sodium } \\
\text { Phosphate }\left(\mathrm{Na}_{2} \mathrm{HPO}_{4}\right)\end{array}$ \\
\hline
\end{tabular}




\subsubsection{Method}

Setup of Lab-Scale Bioretention Cells with 100\% Bioretention Soil Mix (BSM)

The experimental setup includes three PVC pipe test cells (for reproducibility), peristaltic pumps (for delivering the synthetic storm water), a synthetic storm water solution container, valved drains, and a collection pan (Figure 3-2). The water then flowed through the bioretention soil mix, out of the drain on the front and into a collection pan. 1.75 liters of bioretention soil mix (BSM) was placed within the cell and filled the column roughly 75 percent (or up to 5.25 inches). The BSM was measured out using a $250 \mathrm{~mL}$ plastic beaker and placed into a larger, 4 Liter, capped container. After 1.75 Liters was measured, it was shaken by hand for 1 minute to ensure no settling had occurred. The speed and direction was changed randomly throughout the 1 minute period to ensure a homogeneous mixture. The same type of PVC cells with the drain at the bottom were used in BSM-DWTR experiments. Three cells were run during the testing with two containing the WTR plus bioretention soil mix and one containing only the bioretention soil mix. To add the DWTR, the volume was kept constant (1.75 Liter) and the amount of bioretention mix was reduced. The DWTR was added at prescribed percentages (). 

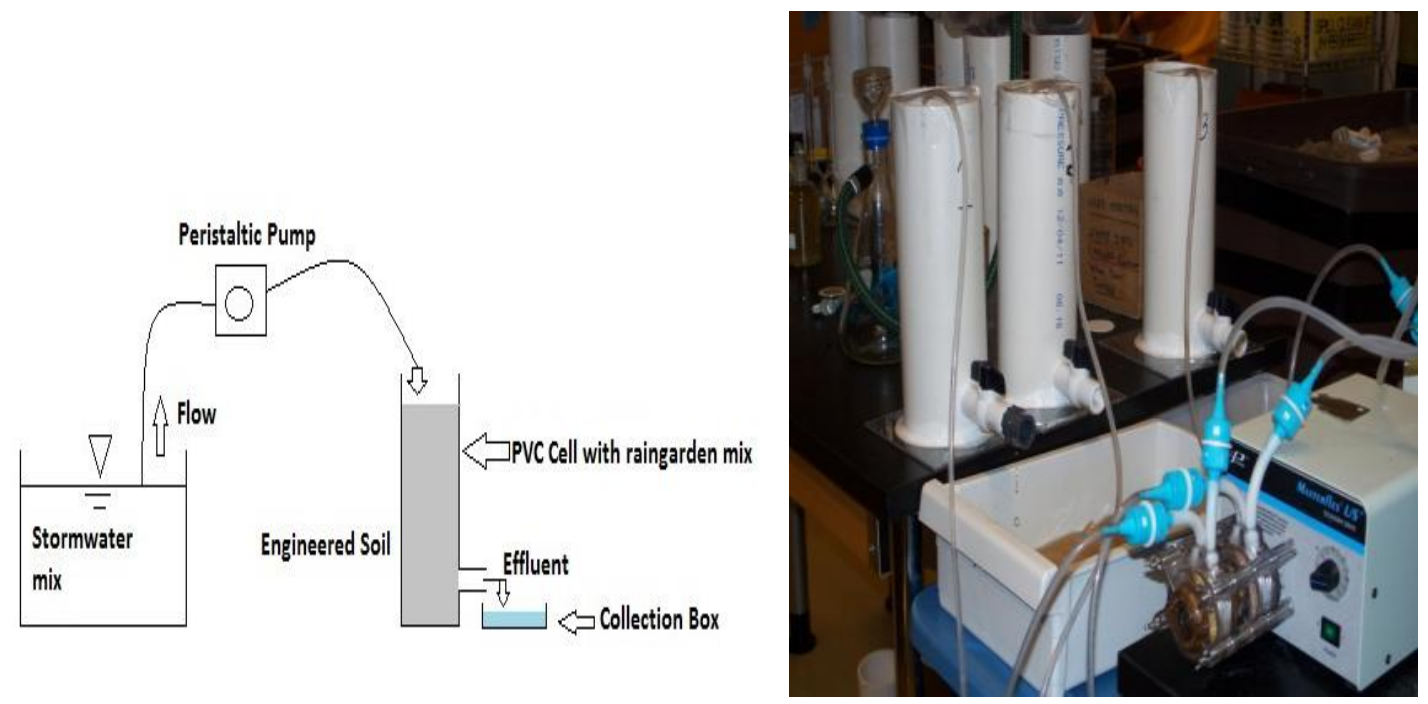

Figure 3- 2: General Setup used in All Tests of PVC Column and Associated Equipment Setup of Bioretention Cells: BSM + Water Treatment Residuals

\section{Peristaltic Pump Setup}

After the synthetic stormwater solution was made, the peristaltic pumps (Masterflex L/S pump) were set to pump $60 \mathrm{ml}$ per minute per pump head. The rate was selected to run the cells with a constant drip at the bottom through the entire test. This flow rate also allowed the cell to be constantly saturated and allow the most contact with all soil mix within the cell. The discharge end of the influent line from the peristaltic pump was then affixed to the top of the PVC cell. The lines were setup so they would drip into the center of cell. The pumps were turned on and the six hour timer was started. Six hours was used to allow the cells to reach an equilibrium or steady state.

\section{Sampling During Testing}

When a sample was taken, $80 \mathrm{~mL}$ was split between two $40 \mathrm{~mL}$ clean glass vial. Each vial was filled, then checked that no air was in the glass jar after the lid was affixed. 
Before the sample was taken, a label was affixed denoting which PVC cell was sampled (i.e. 1, 2, and 3) and at what time the sample was to be started (in minutes). Data was recorded on worksheets similar to what is presented Figure A 1 in Appendix A. After the sample was started, the collection jar was not moved until $120 \mathrm{~mL}$ of sample was captured. This time was typically 2 minutes, but for cells with a slow flow, the sample period may have taken a longer period of time. The samples were placed in the refrigerator after the entire test was completed. A preliminary sample of the stock solution was taken and named "stock". The first sample was taken when effluent water started to flow from the respective cell. After that, samples were taken at 20, 40, 60, 90, $120,180,240,300$, and 360 minutes. Each cell was provided its own timer so the samples could be taken at the respective times. Typically $120 \mathrm{~mL}$ of sample was taken over a two minute period unless the cell was flowing slowly which caused an increase in sample time. The sample was taken from the respective cell, stirred, and then split into the two $40 \mathrm{~mL}$ glass jars. The remaining sample $(40 \mathrm{~mL})$ was tested for $\mathrm{pH}$ using a $\mathrm{pH}$ probe (Thermo-Orion 410A) and turbidity using a turbidimeter (Hach 2100P). The water in-between sampling was discarded.

\section{Orthophosphate (Phosphorous) Testing}

Nutrient testing was completed using either colorimetric testing (Hach Method 8048) or Ion Chromatography (IC, EPA Method 300.1). The colorimetric testing was completed by taking two $10 \mathrm{~mL}$ samples. One sample is used as a "blank" sample and a powder packet is added to the second sample. After a set amount of time, the colorimeter is "zeroed" using the blank sample and then the sample plus powder packet is tested. The 
amount of color present within the test vial corresponds to a concentration of the nutrient that is being tested for.

The IC nutrient testing was completed using a set of blanks, standards, and samples. The IC can run multiple samples at one time and can be time saving as compared to colorimetric testing. To setup the test, reference standards was made of the nutrients to be tested. SPEX CertiPrep (www.spexcertiprep.com) phosphate standard (Item \#: AS-PO49-2Y) was used to make the reference solution. A lower limit and an upper limit nutrient reference standard was made with multiple reference standards in between the upper and lower limit. The reference standards were made from diluting a stock standard which is ordered from a reputable supplier. Small plastic vials $(0.6 \mathrm{~mL})$ were setup in a holder and the reference standards, samples, and deionized (DI) water were placed within them. After each sample was placed in the plastic vial, a filter was pressed into the vial. A typical IC test run would have DI water, followed by the reference samples, DI water, test samples, DI water, another set of reference samples, and DI water at the end. DI water was used to clean the system between the samples so to not interfere with high and low concentration samples. The reference standards were set in order of lowest concentration to highest concentration. The IC interprets the amount of electrical charge and outputs peaks at certain amounts of time. The peaks of the reference solutions are corresponded to their concentration and then the testing sample concentrations are found. Typically the peak to concentration conversion can be completed quickly in a spreadsheet type program (i.e., Microsoft Excel). 


\subsection{CHARACTERIZATION AND SORPTION CAPACITY}

Characterizing the sorption capacity and sorption type of the various DWTRs is important for this research. The sorption capacity shows how much phosphorous (P) by weight can be sorbed onto the drinking water treatment residual (DWTR). The term "sorption" is used over ad- or ab-sorption due to the fact that there could be both types of sorption occurring within the bioretention cell. The residuals used were characterized based on soils characterization methods. The focus of the equilibrium testing was to determine how much phosphorous can be sorbed by each DWTR. From this information, a comparison of residuals collected from mid-Missouri to other residuals reported in the literature was made to determine whether the performances with respect to phosphate sorption are comparable.

\subsection{Types of Metals Present in Drinking Water Treatment Residual Introduction}

The drinking water treatment residuals (DWTRs) were collected from the edge of the sludge lagoons at select drinking water treatment facilities in Mid-Missouri. Precaution was taken to sample the DWTR in the lagoon and not the soil either at the bottom of the lagoon or around the sides. Facilities that use lime (Ca), aluminum sulfate, polyaluminum chloride ( $\mathrm{PACl}$ ), and ferric chloride were chosen for this testing. Most drinking water facilities in Mid-Missouri use a $\mathrm{PACl}$ or $\mathrm{Ca}$ based coagulant and typically has readily abundant quantities in their sludge lagoon. 
Water Treatment Residual Sampling Locations

The materials for these experiments were obtained from drinking water treatment plants around Missouri from their sludge lagoons. Table 4- 1 outlines the locations and types of DWTRs collected.

Table 4- 1: Drinking Water Treatment Residual Sampling Data

\begin{tabular}{|l|l|l|l|l|}
\hline $\begin{array}{l}\text { Name of DWT } \\
\text { Utility }\end{array}$ & $\begin{array}{l}\text { Missouri Water } \\
\text { System No. }\end{array}$ & $\begin{array}{l}\text { Location of DWT Utility } \\
\text { (County / City) }\end{array}$ & $\begin{array}{l}\text { Primary } \\
\text { Coagulant } \\
\text { Added }\end{array}$ & $\begin{array}{l}\text { Sampling } \\
\text { Location }\end{array}$ \\
\hline Brookfield & MO2010105 & Linn / Brookfield & $\begin{array}{l}\text { Aluminum } \\
\text { Sulfate }\end{array}$ & $\begin{array}{l}\text { solids drying } \\
\text { building }\end{array}$ \\
\hline Columbia & MO3010181 & Boone / Columbia & Lime (Calcium) & solids lagoon \\
\hline $\begin{array}{l}\text { Daviess Co } \\
\text { PWSD 3 }\end{array}$ & MO1036130 & Daviess / Lake Viking & $\begin{array}{l}\text { Poly-Aluminum } \\
\text { Chloride }\end{array}$ & solids lagoon \\
\hline Hamilton & MO1010342 & Caldwell / Hamilton & $\begin{array}{l}\text { Poly-Aluminum } \\
\text { Chloride }\end{array}$ & solids lagoon \\
\hline Marceline & MO2010497 & Linn / Marceline & $\begin{array}{l}\text { Aluminum } \\
\text { Sulfate }\end{array}$ & solids lagoon \\
\hline Marceline & MO2010497 & Linn / Marceline & Ferric Chloride & solids lagoon \\
\hline
\end{tabular}




\subsection{Results}

Results of the sorption capacity testing are displayed in Figure 4- 1 and numerically in Appendix B (Table B- 1 through Table B-3). The x-axis unit is the end concentration of the phosphorous solution in $\mathrm{mg} / \mathrm{L}$ of phosphorous remaining in the solution after 24 hours $\left(\mathrm{C}_{\mathrm{e}}\right.$, not up-taken by the DWTR). The y-axis is the loading of phosphorous onto the DWTR in mg of phosphorous sorbed per gram of DWTR $\left(\mathrm{q}_{\mathrm{e}}\right)$. Equation 8 outlines how to obtain the $y$-axis values.

$$
\begin{aligned}
& \mathrm{q}_{\mathrm{e}}=\frac{\left(\mathrm{P}_{\text {initial }}-\mathrm{C}_{\mathrm{e}}\right) * \text { Volume }_{\text {-Solution }}}{\text { Weight }_{\text {DWTR added }}} \\
& \mathrm{q}_{\mathrm{e}}=\text { amount of phosphorous sorbed per gram of sludge }(\mathrm{mg} / \mathrm{g}) \\
& \mathrm{P}_{\text {initial }}=\text { initial phosphorous concentration }(\mathrm{mg} / \mathrm{L}) \\
& \mathrm{C}_{\mathrm{e}}=\text { phosphorous concentration in water after } 24 \text { hours }(\mathrm{mg} / \mathrm{L}) \\
& \text { Volume }_{\mathrm{p}-\text { solution }}=\text { volume of phosphorous solution added (Liter) } \\
& \text { Weight }_{\text {DWTR }}=\text { weight of DWTR added (gram) }
\end{aligned}
$$

The least amount of phosphorous removal was seen by the soil sample near a polyaluminum chloride DWTR lagoon. The soil had $0 \%$ removal at $200 \mathrm{mg} / \mathrm{L}$ of phosphorous solution and only marginal removal ( $0 \%$ to $15 \%)$ at the other concentrations. The lime, ferric chloride, and other polyaluminum chlorides had phosphorous removal efficiencies ranging from $10 \%$ to $19 \%$ at $200 \mathrm{mg} / \mathrm{L}$ of phosphorous solution. 


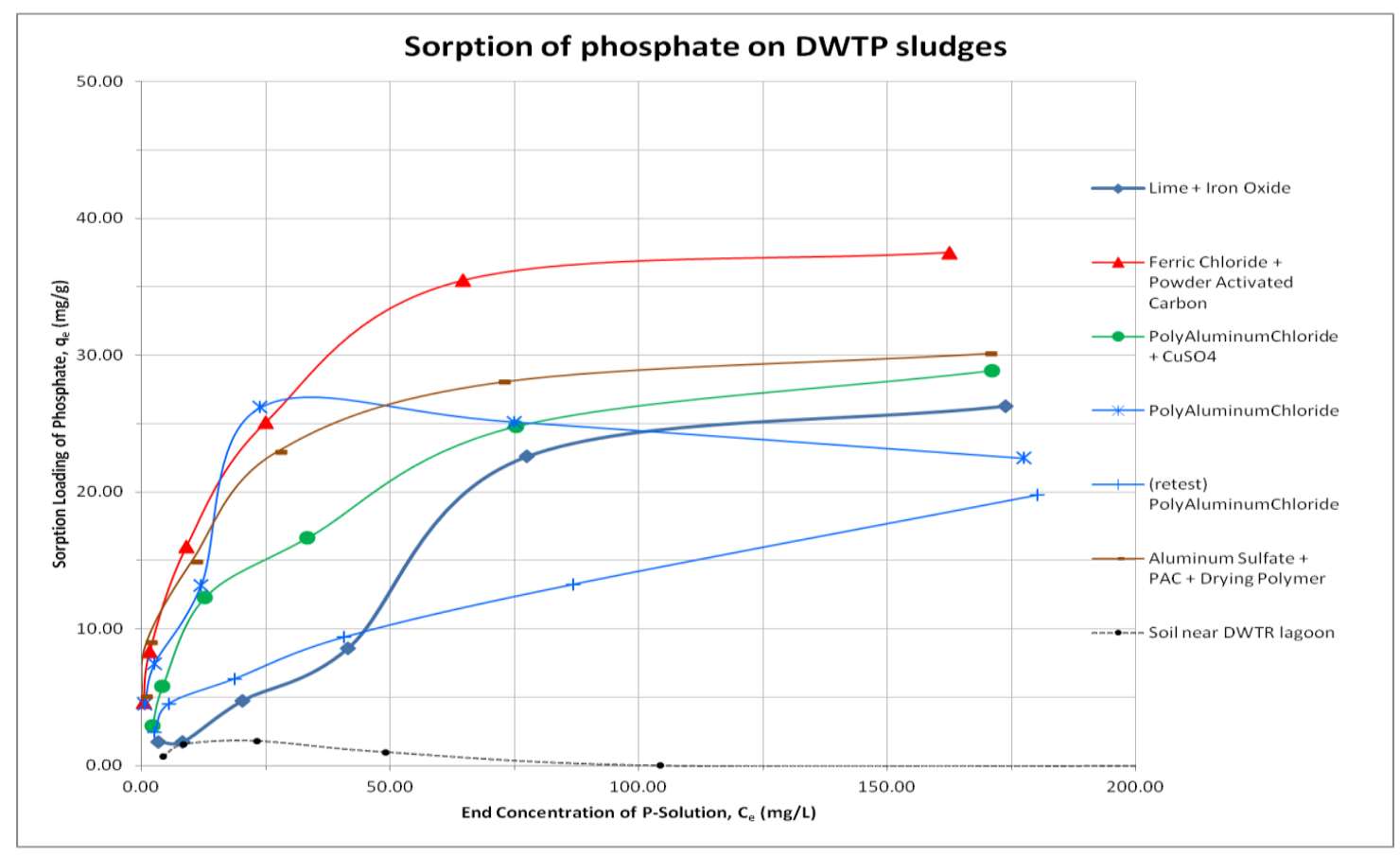

Figure 4- 1: Sorption Loading of Phosphorous After 24 Hour Equilibrium Period. Phosphorous solution concentrations of 5, 10, 25, 50, 100, and $200 \mathrm{mg} / \mathrm{L}$

\subsection{Langmuir and Freundlich Isotherm Modeling}

For isotherm modeling, two models were chosen, the Langmuir and the

Freundlich isotherm models (Equations 9 and 10, respectively). The Langmuir model was originally a gas-solid phase model used to describe the adsorption of activated carbon. It was later extended to include the empirical equilibrium relationships between a bulk liquid and a solid phase. The Langmuir model assumes all sites possess equal affinity for the sorbate. The Freundlich model was derived empirically and later interpreted as a sorption model for surfaces with varying affinities. The Freundlich model assumes the sorption sites to vary in affinity and the stronger bonding sites will get filled before the weaker sites (Foo et al., 2010; Vijayaraghavan et al., 2006). To use the two models, equations presented in Yao et al. (2013) were used. 


$$
\begin{aligned}
& \text { Langmuir } \mathrm{q}_{\mathrm{e}}=\frac{\mathrm{KQC}_{\mathrm{e}}}{1+\mathrm{KC}_{\mathrm{e}}} \\
& \text { Freundlich } \mathrm{q}_{\mathrm{e}}=\mathrm{K}_{\mathrm{f}} \mathrm{C}_{\mathrm{e}}^{\mathrm{n}} \\
& \mathrm{q}_{\mathrm{e}}=\text { amount of phosphorous sorbed per gram of sludge }(\mathrm{mg} / \mathrm{g}) \\
& \mathrm{K}=\text { Langmuir bonding term }(\mathrm{L} / \mathrm{mg}) \\
& \mathrm{K}_{\mathrm{f}}=\text { Freundlich affinity coefficient }\left(\left(\mathrm{mg}{ }^{(1-\mathrm{n})} \mathrm{L}^{\mathrm{n}}\right) / \mathrm{g}\right) \\
& \mathrm{Q}=\text { Langmuir maximum capacity }(\mathrm{mg} / \mathrm{g}) \\
& \mathrm{C}_{\mathrm{e}}=\text { phosphorous concentration in water after } 24 \text { hours }(\mathrm{mg} / \mathrm{L}) \\
& \mathrm{n}=\text { Freundlich linearity constant }(\text { dimensionless })
\end{aligned}
$$

To use equations, 9 and 10, all values were known except for $\mathrm{K}$ or $\mathrm{K}_{\mathrm{f}}$. To solve, the Excel solver function was used. Q was set to the overall maximum capacity for the respective DWTR; $\mathrm{C}_{\mathrm{e}}$ and $\mathrm{q}_{\mathrm{e}}$ were known; and $\mathrm{K}$ or $\mathrm{K}_{\mathrm{f}}$ were solved for. The average values are shown in Table 4- 2 and graphically in Figure B- 1 through Figure B- 6. According to the data, the Langmuir model had a slightly better fit overall as compared to the Freundlich model although in both cases, all the points may be over- or under-estimated. In the case of aluminum sulfate (Figure B- 6), the Freundlich model over-estimated the entire range of values. Overall for Missouri, the use of the Langmuir would be best to use because it has a better $\mathrm{R}^{2}$. The Langmuir model also did not grossly over-estimate like the Freundlich model did. 
Table 4- 2: Adsorption Isotherm Data - Langmuir and Freundlich Models

\begin{tabular}{|c|c|c|c|c|c|c|}
\hline \multicolumn{7}{|c|}{ Adsorption Isotherms Data } \\
\hline & \multicolumn{3}{|c|}{ Langmuir } & \multicolumn{3}{c|}{ Freundlich } \\
\hline DWTR & $\mathrm{K}$ & $\mathrm{Q}$ & $\mathrm{R}^{2}$ & $\mathrm{~K}_{\mathrm{f}}$ & $\mathrm{n}$ & $\mathrm{R}^{2}$ \\
\hline Lime + Iron Oxide & 0.026 & 26.3 & 0.78 & 5.62 & 0.155 & 0.77 \\
\hline Ferric Chloride + PAC & 0.194 & 37.5 & 0.79 & 11.52 & 0.182 & 0.82 \\
\hline Polyaluminum Chloride + CuSO4 & 0.058 & 28.9 & 0.82 & 8.94 & 0.1404 & 0.83 \\
\hline Polyaluminum Chloride & 0.199 & 26.2 & 0.77 & 12.61 & 0.0789 & 0.73 \\
\hline $\begin{array}{c}\text { (Retest) Polyaluminum Chloride } \\
\text { Aluminum Sulfate + PAC + Drying } \\
\text { Polymer }\end{array}$ & 0.035 & 19.8 & 0.79 & 6.44 & 0.0915 & 0.80 \\
\hline
\end{tabular}




\subsection{Discussion}

The metals: calcium, polyaluminum chloride, aluminum sulfate and ferric chloride had an overall mid-range sorption of phosphorous from 20 to $40 \mathrm{mg}$ of phosphorous per gram of DWTR (Table 4- 3). Agyin-Birikorang et al. (2009) found their DWTR to sorb up to $10 \mathrm{mg}$ phosphorous per gram DWTR. This is similar to what this study found. The difference could be attributed to many different factors which might include type of coagulant used, amount of coagulant used, and source water characteristics. A conclusion may be drawn that most facilities in Missouri have a phosphorous loading capacity in the range of the grouping shown in Figure 4- 1. When considering use of locally available DWTRs, a similar analysis would be required.

Sampling location is also very important when considering the use of a DWTR. Although the center of the lagoon is going to have the best sample, it is almost impossible to get to the center of the lagoon without some type of boat unless the lagoon is drained and dried. Because sampling can only easily be done near the edge, it is best to pull multiple samples and make an aggregate sample to best describe the DWTR within the lagoon. 
Table 4- 3: Maximum Phosphorus Sorption Capacities and Event Based Need of DWTR to Sequester All of the Phosphorous

\begin{tabular}{|c|c|c|}
\hline Type of DWTR & $\begin{array}{c}\text { Maximum } \\
\text { Phosphorous } \\
\text { Loading at 24 } \\
\text { hr (mg/g) }\end{array}$ & $\begin{array}{c}\text { Amount } \\
\text { Needed (kg) }\end{array}$ \\
\hline Soil Sample & 1.7 & 30 \\
\hline $\begin{array}{c}\text { Aluminum Sulfate + PAC + } \\
\text { Drying Polymer }\end{array}$ & 19 & 3 \\
\hline PolyAluminumChloride & 25 & 2 \\
\hline Lime + IronOxide & 26 & 2 \\
\hline $\begin{array}{c}\text { PolyAluminumChloride + } \\
\text { CuSO4 }\end{array}$ & 28 & 2 \\
\hline Ferric Chloride + PAC & 30 & 2 \\
\hline Ferric Chloride + PAC & 37 & 1 \\
\hline
\end{tabular}

\subsubsection{Phosphorous Reduction in Stormwater Analysis}

To complete the phosphorous reduction analysis of DWTR, a storm, area, influent phosphorous concentration, and maximum capacity of the DWTR must be taken into account. To compute this, a 1-inch rainfall depth over a 1-acre area was assumed. The average phosphorous content of the water was also assumed to be $0.5 \mathrm{mg} / \mathrm{L}$. The three DWTRs chosen for analysis were the $\mathrm{Ca}$, ferric chloride + PAC, and aluminum sulfate. The values in Table 4- 3 represent the amount of DWTR needed to sequester the 51.4 grams of phosphorous contained within the storm event. 


\subsection{LAB SCALE BIORETENTION MEDIA PERFORMANCE}

\section{Introduction}

The main goal for the testing of the lab-scale bioretention cells was to quantify how much phosphorous was present in the effluent water as compared to the influent water and thus demonstrate removal efficiencies of various soil mix configurations. Phosphorous reduction can only be accomplished by some type of uptake (it does not decay naturally) (Environmental Protection Agency, 2012b). The uptake mechanism may be by plant action, microbe action, or chemical precipitation. Plant reduction and microbe reduction were not tested here, but reduction by DWTR metals was. The metals used were DWTRs in the form of calcium (Ca), aluminum (Al), and iron (Fe). The DWTRs were mixed into the lab-scale bioretention cells at prescribed rates following the method presented in Chapter 3. In both types of tests, bioretention soil mix (BSM) only and bioretention mix plus BSM-DWTR, the lab scale bioretention cells had a known phosphorous-content stormwater solution pumped into them and then the effluent water was tested. The mix ratios chosen provide a range of mix configurations intended to allow for prescription of which mix ratio would be most appropriate for full-scale applications. 


\subsection{Bioretention Media Characteristics}

\subsubsection{Introduction}

Before and after each of the DWTR testings was done, a sample of the soil was taken to the Soil Characterization Lab (SCL) located in Thomas and Nell Lafferre Hall at the University of Missouri-Columbia. To characterize the soil, eight tests were performed including: (1) cation exchange capacity (CEC), (2) plant available phosphorus (Bray P1), (3) water and salt $\mathrm{pH},(4)$ nitrogen $(\mathrm{N})$, phosphorous $(\mathrm{P})$, potassium $(\mathrm{K})$, calcium $(\mathrm{Ca})$, magnesium $(\mathrm{Mg})$, iron $(\mathrm{Fe})$, aluminum $(\mathrm{Al})$, and manganese $(\mathrm{Mn}),(5)$ total organic carbon (6) texture, and (7) electro-conductivity. The goal of these tests was to be able to characterize the soil before and after the DWTR testing to show any notable changes within the cell due to the addition of $\mathrm{Ca}, \mathrm{Al}$, or Fe solids. The following discussion of the purpose for each test was adapted from Brady et al. (2008).

Cation exchange capacity (CEC) is the factor within soil which measures the ability for ions to attach and detach from areas of ion-exchange. These areas are extremely important for ion adsorption and overall soil health. Overall CEC does not always detail the available portions of the soil, details regions of the soil structure in which the ions are deemed not easily plant available. When it comes to traditional CEC in a natural soil environment, not engineered, calcium is usually the over-bearing ion in adsorption in percentages over 50-60\% while magnesium is next around 5-15\% of overall CEC. The rest of the CEC percentage is held by all other cations. Because these are prescribed soil mixes, the expectations for CEC would be low unless there was a high percentage of calcium (e.g. sand derived from limestone). 
Plant available phosphorus is phosphorus found within the soil solution available for plant absorption. This form of phosphorus is overwhelmingly found in the soil environment as $\mathrm{PO}_{4}{ }^{3-}$.

$\mathrm{pH}$ has a large effect on the availability of nutrients within the soil environment. Macronutrients and micronutrients can fluctuate in and out of availability as $\mathrm{pH}$ fluctuates. This means the soils ability to capture nutrients/pollutants changes can be adjusted depending on what pollutant is most important for media Under normal soil conditions the ability to lower $\mathrm{pH}$ is difficult because of the buffering capacity that calcium and other cations impart upon the soil.

Nitrogen is one of the the most volatile and fluctuating elements within the soil environment and is the most limiting, in most cases, for plants. Unfortunately its ability to leach through the soil media is far greater than most ions. When it evolves into the anion phases of NO2-, NO3- it flows quickly through soil and contributes to nutrient influxes in stream systems and particularly estuaries.

Potassium is another cation necessary for proper plant growth, particularly in the beginning stages of plant growth. Fortunately it is not easily lost in soil and is bonded quickly to clay surfaces and then taken up by plants. However, it is very soluble in water and is found abundantly in the ocean.

Calcium is extremely important as a macronutrient for plant nutrition as well as maintaining proper $\mathrm{pH}$ and buffering capacity within soil. It is a cation in the soil structure and is not lost through the soil profile, but rather it is taken up by the plant and comes out of exchange sites and into solution to buffer $\mathrm{pH}$ values. Magnesium follows 
much of the same pathways as $\mathrm{Ca}$ in soil, but in smaller quantities in most cases. The ratio of $\mathrm{Ca}: \mathrm{Mg}$ in most healthy soils ranges from 6 to 10:1.

Iron and aluminum are rarely found in soil solution, but rather within soil structure itself. As minerals weather, isomorphic substitution occurs and allows $\mathrm{Fe}^{2+}$ and $\mathrm{Al}^{3+}$ to substitute for $\mathrm{Si}^{4+}$ within the structure of soils. This property is crucial to modern soil understanding in that this gives the soil an overall charge to be able to exchange and hold cations. This substitution gives the soil substrate an overall negative charge. Cations are then able to be adsorbed to the surface of the soil and then released as it is depleted within the soil solution.

Total active carbon can be tested in the field easily with a potassium permanganate solution and results can be viewed quickly. Soil organic carbon can be measured from the soil organic matter (SOM) of the soil itself. SOM carbon is usually $50 \%$ by mass of total SOM. SOM over time evolves into humic substances and gives the soil a much greater ability to buffer many pollutants and acts as a chelating agent of the soil. Humic substances form extremely long complexes over time and are identified as compounds attached to compounds with no identifiable structure. This gives the ability of the soil to accept complexes of both aromatic and aliphatic character. Unfortunately humic substances also take available nutrients in some cases out of solution and into the structure, making these nutrients not plant available.

Texture characterizes the proportions of sand, silt, or clay in a substrate. In general, having a soil high in clays imparts low permeability, while containing nutrients and pollutants. The opposite, therefore, can be found in soils with high amounts of sand. 
Electrical conductivity in the soil is one way to measure soil salinity and sodicity (Na). Higher conductance of the bulk soil or soil solution represents more salt present. Field EC meters are rather inaccurate or have a very large window of error and it usually takes a lab soil solution extraction to get a very reliable reading of the soil EC.

\subsubsection{Results}

All of the results from the DWTR addition tests were compared to a BMP soil that was recently installed at a bioretention cell. The bioretention cell that was tested used a BMP soil mix that was sourced from the Mid-Missouri area while the BMP soil mix that was lab-tested was created using an Eastern Missouri soils (St. Louis, MO). The BMP soil has been in place for about 6 months. Table D- 1outlines the size characteristics of the tested soils. The percent sand size particle $(0.05-2.00 \mathrm{~mm})$ was greater than $65 \%$ for each sample with a maximum of $95 \%$. All of the Ca-DWTR had a slightly higher silt fraction $(0.002-0.05 \mathrm{~mm})$ along with the $10 \%$ and $20 \%$ Fe-DWTR. The BMP soil has a higher silt and clay $(<0.002 \mathrm{~mm})$ than all of the DWTR addition samples. The BMP soil's higher clay and silt fraction could be due to some siltation. All of the categories fall within sand, loamy sand, or sandy loam when using a soil textural triangle.

The Ca-DWTR had the highest concentration of Ca bases (meq/100g, Table D2). This was to be expected as the Ca-DWTR is calcium based. The Fe-DWTR had the next highest concentration while the Al-DWTR had the lowest concentration of Ca. The magnesium, sodium, and potassium values were all roughly the same across the $\mathrm{Ca}-, \mathrm{Fe}-$, and Al-DWTR. Comparing this to the bioretention cell, the Ca-DWTR calcium values were double, Fe-DWTR calcium values were about the same, and the Al-DWTR calcium 
values were about half. In all if the situations, the $\mathrm{pH}$ was above 5.5 which means no aluminum was mobile, therefore all the values were zero (NRCS, 2004).

The CEC (meq /100g) for a sand ranges from 2-5 while a sandy loam ranges from 5 to 12 (Nathan, 2009). With higher amounts of clay, the CEC can be increased to near 40 (clay and clay loams). The CEC for the Ca-DWTRs was the highest near 30 (Table D3). The high CEC content could be attributed to the addition of calcium which increases CEC. The Fe-DWTR had a range of CEC values from 12 to 25 which could range from a soil type of sandy loam to silt-clay-loam. This is in line again with the calcium content of the Fe-DWTR, as the calcium content went up, the CEC increased as well. The AlDWTR had the lowest CEC around 7.5 which is closest to a sand or sandy loam. This is evident from the low amount of calcium overall in the sample.

Water $\mathrm{pH}$, salt solution $\mathrm{pH}$ and available phosphorous was also tested (Table D4). Typically salt solution $\mathrm{pH}$ is used in agricultural applications because it typically stays more constant than water $\mathrm{pH}$ with seasonal variations. The salt solution $\mathrm{pH}$ is typically around $0.5 \mathrm{pH}$ units below the water $\mathrm{pH}$ values. The water $\mathrm{pH}$ for all the samples ranged from 7.5 to 8.7 with the Ca-DWTR having the highest $\mathrm{pH}$ and the Al-DWTR having the lowest $\mathrm{pH}$. The salt $\mathrm{pH}$ ranged from 7.5 to 8.0. The available phosphorous, in most cases, increased from pre-test to post-test. The 20\% Ca-DWTR and 5\% Al-DWTR available phosphorous decreased from pre-test to post-test. Overall, the Fe-DWTR had the most available phosphorous while the Ca-DWTR had the least amount of available phosphorous. The Ca-DWTR also started with the lowest amount of available phosphorous and after testing still had the lowest amount of available phosphorous. During the equilibrium testing, it was found that the Ca-DWTR had the lowest sorption 
of phosphorous which explains the low values of available phosphorous. The Fe had the highest amount of available phosphorous. This could possibly mean that all the sorption sites are used and there is phosphorous loosely bound to the Fe-DWTR. The Al-DWTR available phosphorous amounts did not drastically change overall. This could be due to sorption sites still available. This can be correlated to cell testing because during cell testing the effluent water did not carry any phosphorous for the Al-DWTR. 


\subsection{Bioretention Media Performance}

The bioretention cells were made with a single type of bioretention mix from St. Louis Compost in St Louis, MO. The media is $80 \%$ sand, $10 \%$ mulch, $5 \%$ top soil, and $5 \%$ compost. The main purpose of the mix is to allow higher infiltration than native soils, provide reduction of trash and other pollutants, and also allow plant growth within the media. The main reduction in nutrients is completed by plant uptake action in cells using only BSM. Some reduction may be seen with clays as well. In the lab, plants were excluded and no clay was added to the bioretention mix. During the experiments it was seen that without addition of DWTRs, there was no ponding of water on top of the bioretention media and the media was relatively quick draining. The phosphorous index can influence the amount of phosphorous in the effluent. A phosphorous index is typically completed in agriculture fields and takes into account the possible sources of phosphorous being introduced into the system and how the phosphorous could leave the system (Bhumbla, 2013). The possible sources of phosphorous for our system include the influent water, the BSM sand, and the BSM organic matter.

\subsection{Bioretention plus DWTR Addition Performance}

The DWTR addition was completed using calcium from Columbia, MO, ferric chloride residuals from Marceline, MO, and aluminum sulfate residuals from Brookfield, MO. The DWTR solids were mixed using a large capped container that was shaken by hand in a random nature for one minute to ensure the DWTR was thoroughly mixed with the BSM. The test was run using a synthetic storm water with a phosphorous concentration of $6.2 \mathrm{mg} / \mathrm{L}$. The higher amount of phosphorous in the water was due to the higher sorption of phosphorous possible through the DWTR. After each test, soil samples 
were taken to the soil characterization lab for analysis. At 5\%, 10\%, and $20 \%$ Ca DWTR the pumps needed to be turned off due to significant ponding and back on when the water level decreased. At $10 \%$ and $20 \%$ Fe DWTR the pumps also needed to be turned off and on due to ponding. The Al DWTR only had one case of significant ponding at $10 \%$ DWTR with only one cell. If a bioretention cell ponds water quickly, it poses a risk of flooding and does not meet its design considerations as a pollutant reduction BMP.

\subsection{Results}

\subsubsection{Bioretention Mix (No DWTR Addition)}

For each test, a fresh sample of BSM was used. Multiple five gallon buckets of BSM were collected at St. Louis Compost. During transport a lid was placed on top so no soil was lost, and upon returning to the lab, the lid was removed. The BSM-only test was completed using $100 \%$ bioretention mix (no DWTR addition). After every test, the soil was discarded and the columns were cleaned of any remaining BSM. The columns were cleaned by first wiping the inside of the PVC column with a paper towel then washing any remaining residuals out of the column using tap water. Each PVC column was then dried with a paper towel and allowed to further air dry between testing. During the BSMonly (no DWTR addition) testing, no ponding was observed on the surface of the media. There was a variable amount of lag time between the pump being turned on (water being fed into the cell) and the effluent drain starting to flow (Table 5- 1). This is most likely due to the wetting of the soil occurring within the cell. Although $80 \%$ of the cell is sand, the other $20 \%$ is organic matter which absorbs some water. 
Table 5- 1 Lag Times between Pump Turn-On and Water Flow from Cell

\begin{tabular}{|c|c|c|c|}
\hline Test \# & $\begin{array}{c}\text { Bioretention } \\
\text { Mix } \\
\text { (Percent) }\end{array}$ & $\begin{array}{c}\text { DWTR } \\
\text { Addition } \\
\text { (Percent) }\end{array}$ & $\begin{array}{c}\text { Lag Time } \\
\text { (minutes) }\end{array}$ \\
\hline Test 1 & 100 & 0 & 9 \\
\hline Test 1 & 100 & 0 & 9 \\
\hline Test1 & 100 & 0 & 14 \\
\hline Test 2 & 100 & 0 & 20 \\
\hline Test 2 & 100 & 0 & 15 \\
\hline Test 3 & 100 & 0 & 15 \\
\hline Test 3 & 100 & 0 & 7 \\
\hline Test 4 & 100 & 0 & 7 \\
\hline Test 4 & 100 & 0 & \\
\hline
\end{tabular}

After the cell started to flow, there was a spike of phosphorous and turbidity in the effluent water. This spike can be seen in the test results Figure C- 1 through Figure C- 4. The $\mathrm{x}$-axis is the time at which each sample was taken after flow was recorded and the $\mathrm{y}$ axis is the relative concentration of effluent phosphorous to influent phosphorous (Equation 11).

Relative Concentration $=\frac{C_{i}}{C_{0}}$

$$
\begin{aligned}
& \mathrm{C}_{\mathrm{i}}=\text { concentration of phosphorous at specified time }(\mathrm{mg} / \mathrm{L}) \\
& \mathrm{C}_{0}=\text { concentration of phosphorous in influent water supply }(\mathrm{mg} / \mathrm{L})
\end{aligned}
$$


A number higher than 1 indicates the effluent phosphorous was greater than the influent phosphorous and a number less than 1 indicates the effluent phosphorous is less than the influent phosphorous. Samples were initially taken at 20 minute intervals to capture the change in water quality. As the test time increased, the water quality did not change as rapidly and sampling was done at 30 minute or 60 minute intervals.

The first sample was collected when flow started from the effluent drain on the PVC cell. At testing time zero, higher than influent amounts of phosphorous were recorded in the water and continued to be higher than influent throughout the testing. This could be due to a high phosphorous content within the bioretention mix itself and the bioretention mix not being able to uptake phosphorous. Results are shown in graphical and numerical format in Appendix C (Figure C- 1 through Figure C- 4 and Table C- 1 through Table C- 4). An error analysis of tests 1 through 3 (Figure 5- 2, Table C- 5) was also completed excluding the only outlier (Test 2, Cell 2, 90 minutes). Test 4 was excluded due the higher amount of influent phosphorous. All but one (test 2, 180 minutes) of the average test data points fall within the $95 \%$ confidence interval when excluding the test 2 outlier. Tests 1 through 3 showed that phosphorous is not sorbed within in the cell and may readily leach from the cell. It was also shown, after 6 hours, the cells release around two times the influent phosphorous. This is mainly due to the large amount of sand material in the cell not being able to uptake phosphorous. 


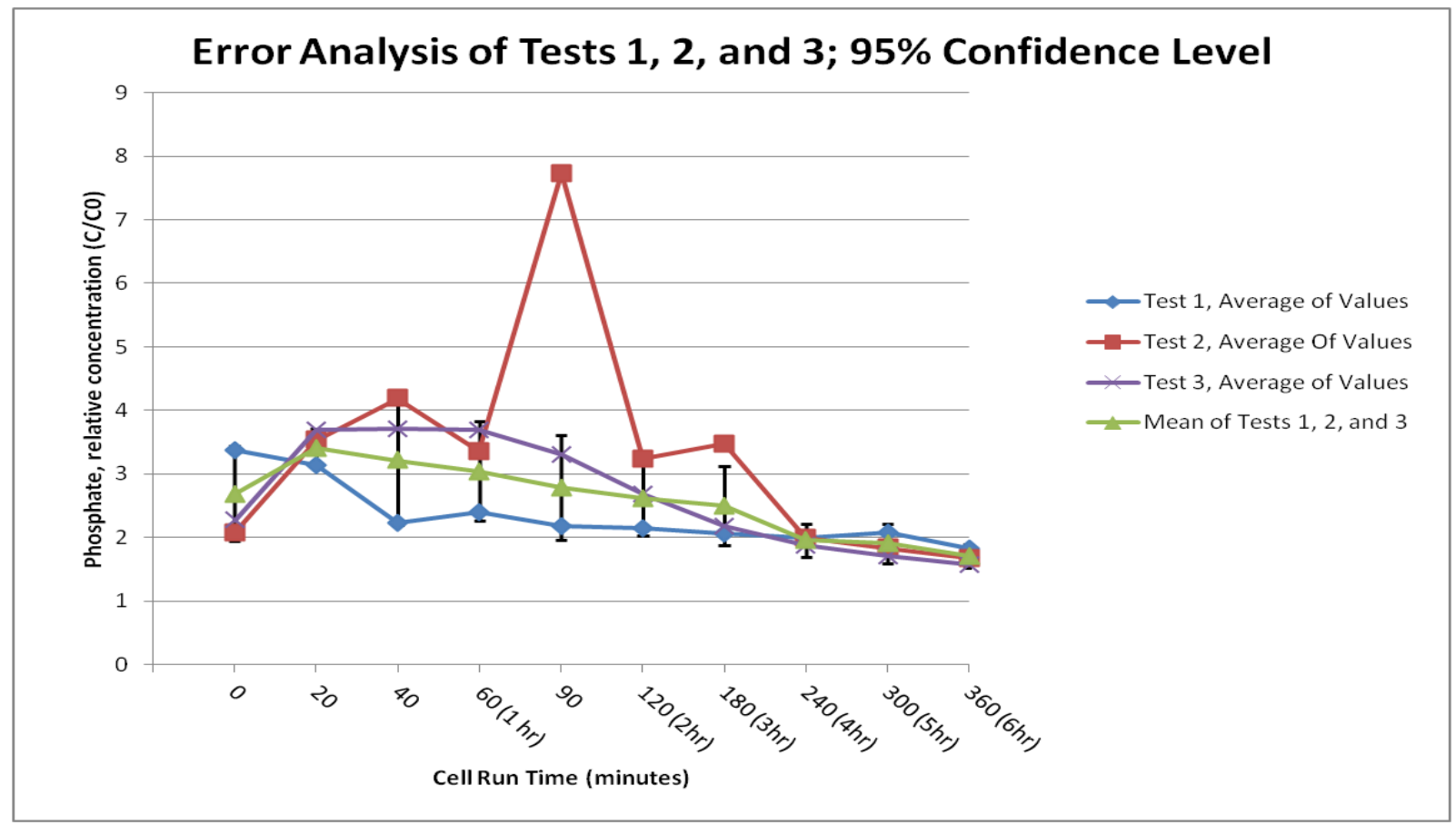

Figure 5- 2: Bioretention Cell Tests 1 through 3 Error Analysis - 100\% Bioretention Mix, $0.4 \mathrm{mg} / \mathrm{L}$ of influent phosphorous at $60 \mathrm{~mL} / \mathrm{min}$

\subsubsection{Bioretention Mix Plus Drinking Water Treatment Residuals}

Calcium $(\mathrm{Ca})$, ferric $(\mathrm{Fe})$, and aluminum (Al) DWTRs were tested by using the method outlined in Section 3.2.3. In each scenario two cells were setup with $\mathrm{Ca}, \mathrm{Fe}$ or $\mathrm{Al}$ DWTRs at a prescribed ratio (5\%, 10\%, and 20\% DWTR). During the testing no ponding occurred in the $100 \%$ bioretention mix. As seen in previous tests, water started to flow from the $100 \%$ bioretention mix cells with only a small lag time (up to 20 minutes). The Ca cells $(5 \%, 10 \%$, and $20 \%)$ initially took water in with no ponding and then started to pond after the media was saturated (Table C- 6). The cells did not pond at the same rates. During testing the pumps supplying water would have to be turned off to the DWTR addition cells to avoid overtopping the cells. The pumps would be turned back on when the ponding was only 1 inch over the surface of the DWTR/bioretention mix surface. The same amount of ponding occurred during the $10 \%$ and $20 \%$ Fe DWTR addition while 
ponding was not an issue with the 5\% Fe DWTR addition (Table C- 7). During the Al DWTR testing, only one of the $10 \%$ Al DWTR addition cells ponded significantly enough to have the pumps turned off (Table C- 8). The lag times for $20 \% \mathrm{Ca}$ and Fe were around 30 minutes and decreased to 8 minutes for the 5\% DWTR addition (Table C- 9). The Al DWTR did not have the same trend with all lag times around 8 minutes for $5 \%$, $10 \%$, and $20 \%$ (Table C- 9).

Test 5 was run with no phosphorous in the influent water to address any questions about the DWTR releasing phosphorus (Figure 5- 3,). Throughout test 5, there was no release of phosphorous from cell 1 and 2 (20\% Ca DWTR addition) but there was a release of phosphorous from cell 3 (no DWTR addition).

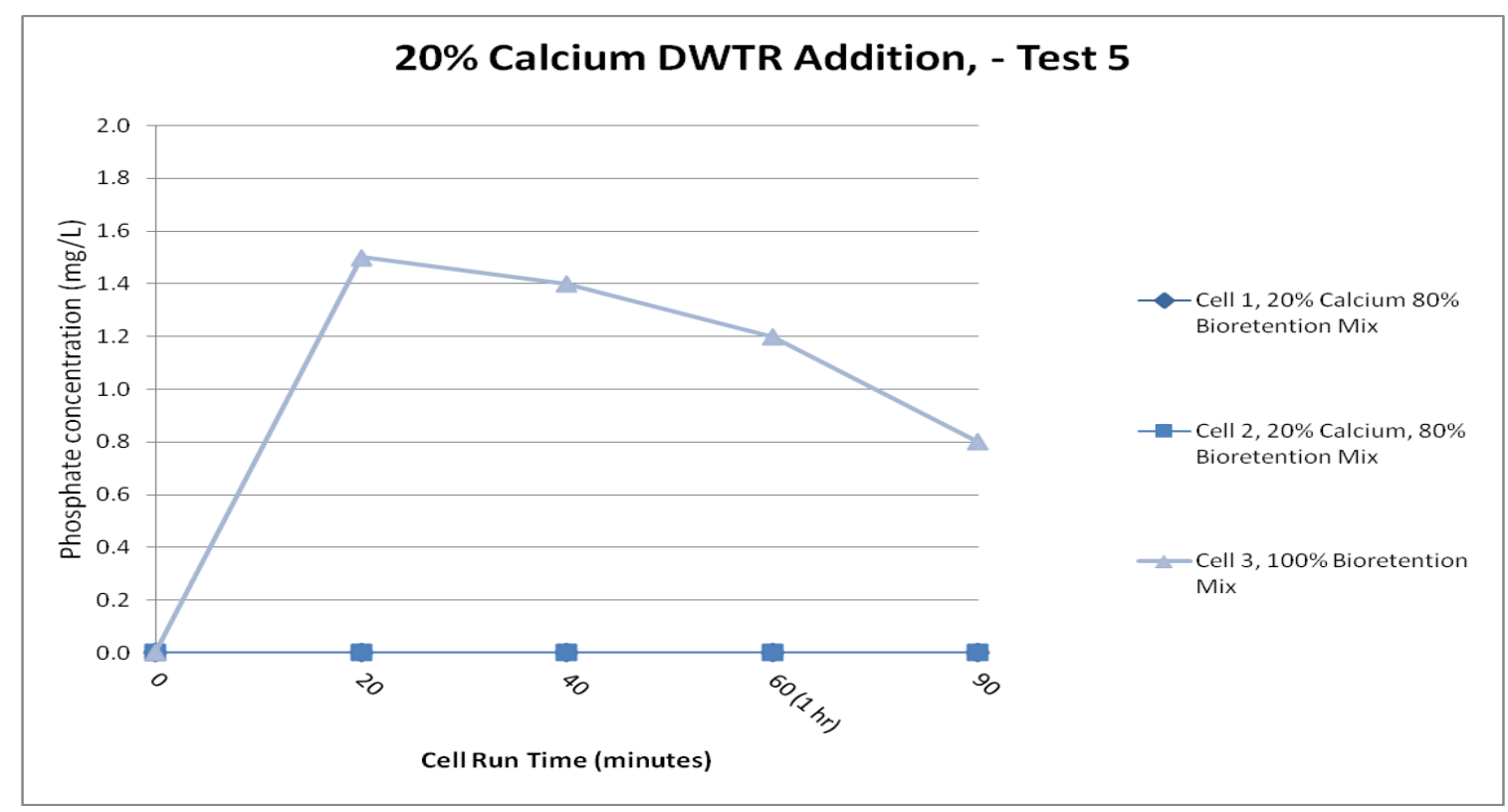

Figure 5- 3: Bioretention Cell Test 5-80\% BSM + 20\% Calcium DWTR Addition, 0 $\mathrm{mg} / \mathrm{L}$ of influent phosphorous at $60 \mathrm{~mL} / \mathrm{min}$ 
During Test 6 (Figure 5- 4, Table C- 10) 5\%, 10\%, and 20\% Ca DWTR additions were tested using $6.2 \mathrm{mg} / \mathrm{L}$ of phosphorous in the influent at a $60 \mathrm{~mL} / \mathrm{min}$ rate into the cell. All cells showed a reduction in phosphorous. Cell 1only has three data points due to the very slow flow of the water through the cell inhibiting sample collection. Cell 2 showed some phosphorous in the effluent water after 40 minutes suggesting that the sorption capacity of the amendment was becoming exhausted or the phosphorous uptake rate is slower than that of the phosphorous loading but overall the effluent phosphorous stayed below $1 \mathrm{mg} / \mathrm{L}$ concentration (approx. 84\% reduction). Cell 3 and 4 (10\% Ca DWTR addition) both followed the same trend as the $20 \%$ Ca DWTR addition. Cell 5 and 6 (5\% Ca DWTR addition) started to release phosphorous at the 20 minute mark and steadily climbed to above $2 \mathrm{mg} / \mathrm{L}$ (approx. $54 \%$ reduction) at the 180 min mark.

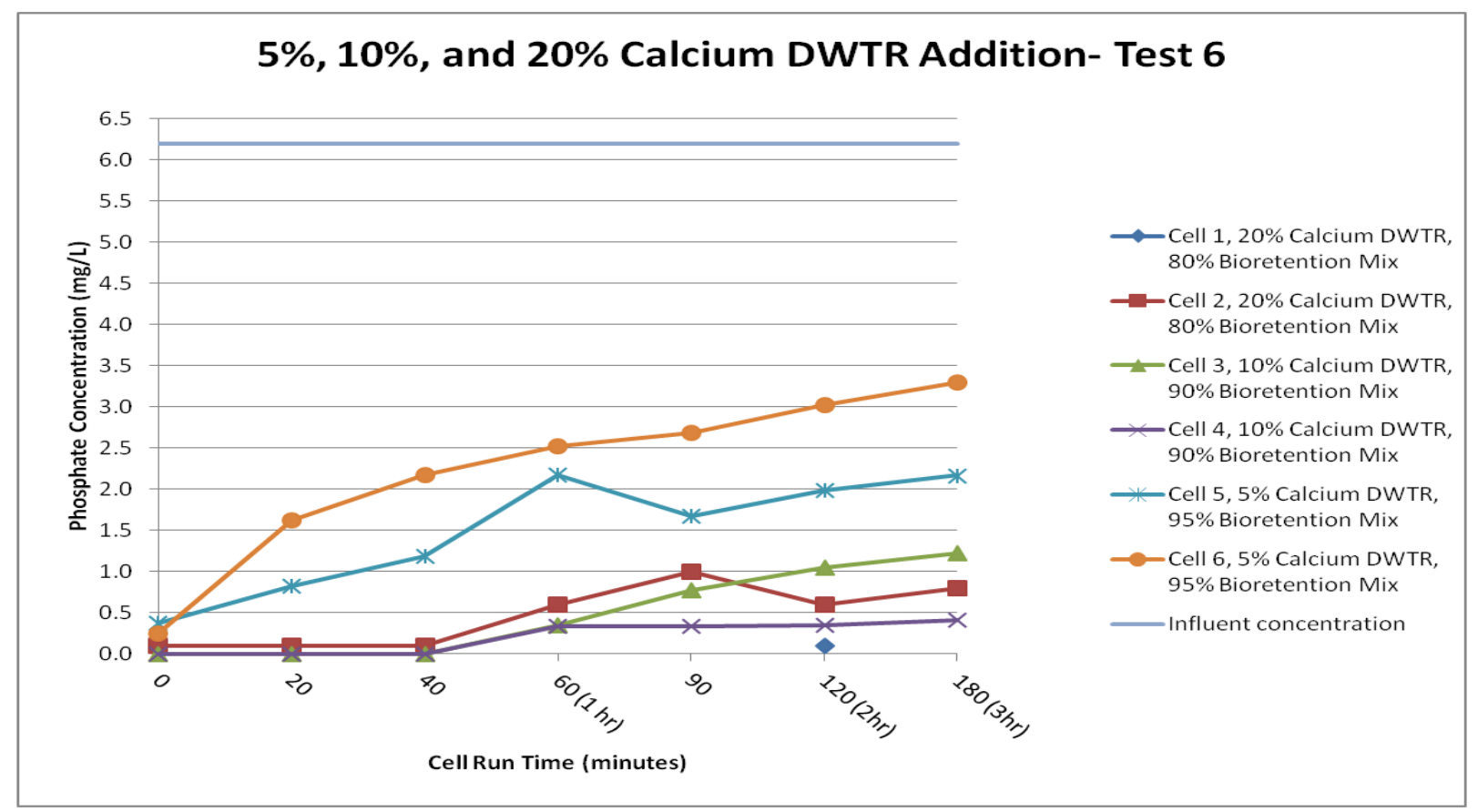

Figure 5- 4: Bioretention Cell Test 6-5, 10, and 20\% Calcium DWTR Addition, 6.2 $\mathrm{mg} / \mathrm{L}$ of influent phosphorous at $60 \mathrm{~mL} / \mathrm{min}$ 
Test 7 (Figure 5- 5, Table C- 11) was completed using Fe DWTRs at mix ratios of $5 \%, 10 \%$, and $20 \%$. The Fe DWTR again exhibited phosphorous reduction throughout the testing procedure. The overall phosphorous effluent of cells 1 through 4 (20\% and $10 \%$ Fe DWTR addition) was zero throughout the testing. Cells 5 and 6 both showed phosphorous in the effluent water at the 90 minute mark and increased up to $1 \mathrm{mg} / \mathrm{L}$ (approx. 88\% reduction) at the end of testing (180 minutes).

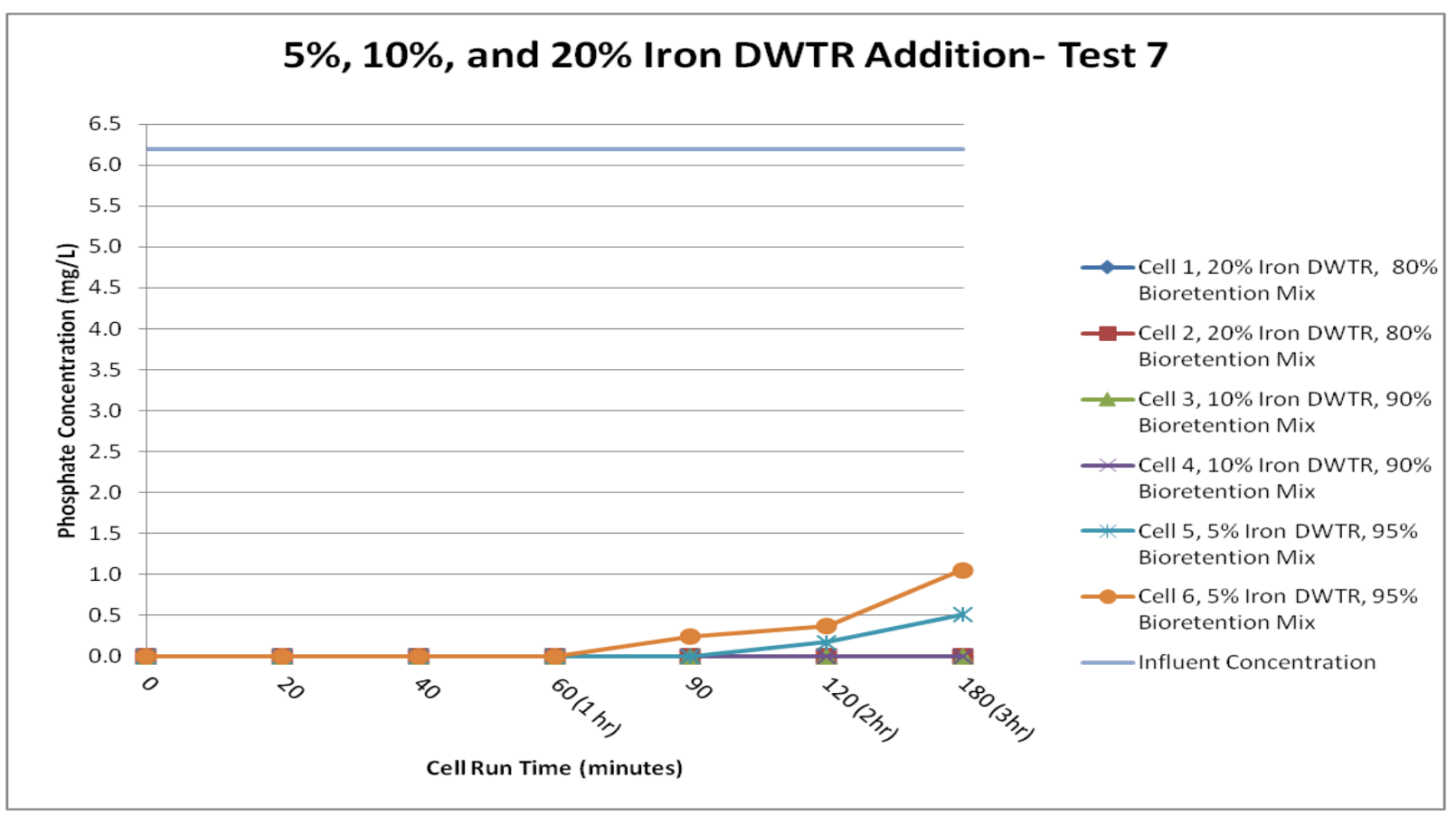

Figure 5- 5: Bioretention Cell Test 7 - 5, 10, and 20\% Iron DWTR Addition, $6.2 \mathrm{mg} / \mathrm{L}$ phosphorus in influent water at $60 \mathrm{~mL} / \mathrm{min}$ 
Test 8 (Figure 5- 6, Table C- 12) was completed using Al DWTRs at mix ratios of $5 \%, 10 \%$, and $20 \%$. All cells (1 through 6) showed no phosphorous release during the entire testing period. This represents that during the testing, the amount of phosphorous in the influent water was all sorbed by the Al DWTR solids. This also shows that there were enough sorption sites on the Al DWTR to sorb phosphorous at a rate of $6.2 \mathrm{mg} / \mathrm{L}$ (approx 99\% reduction).

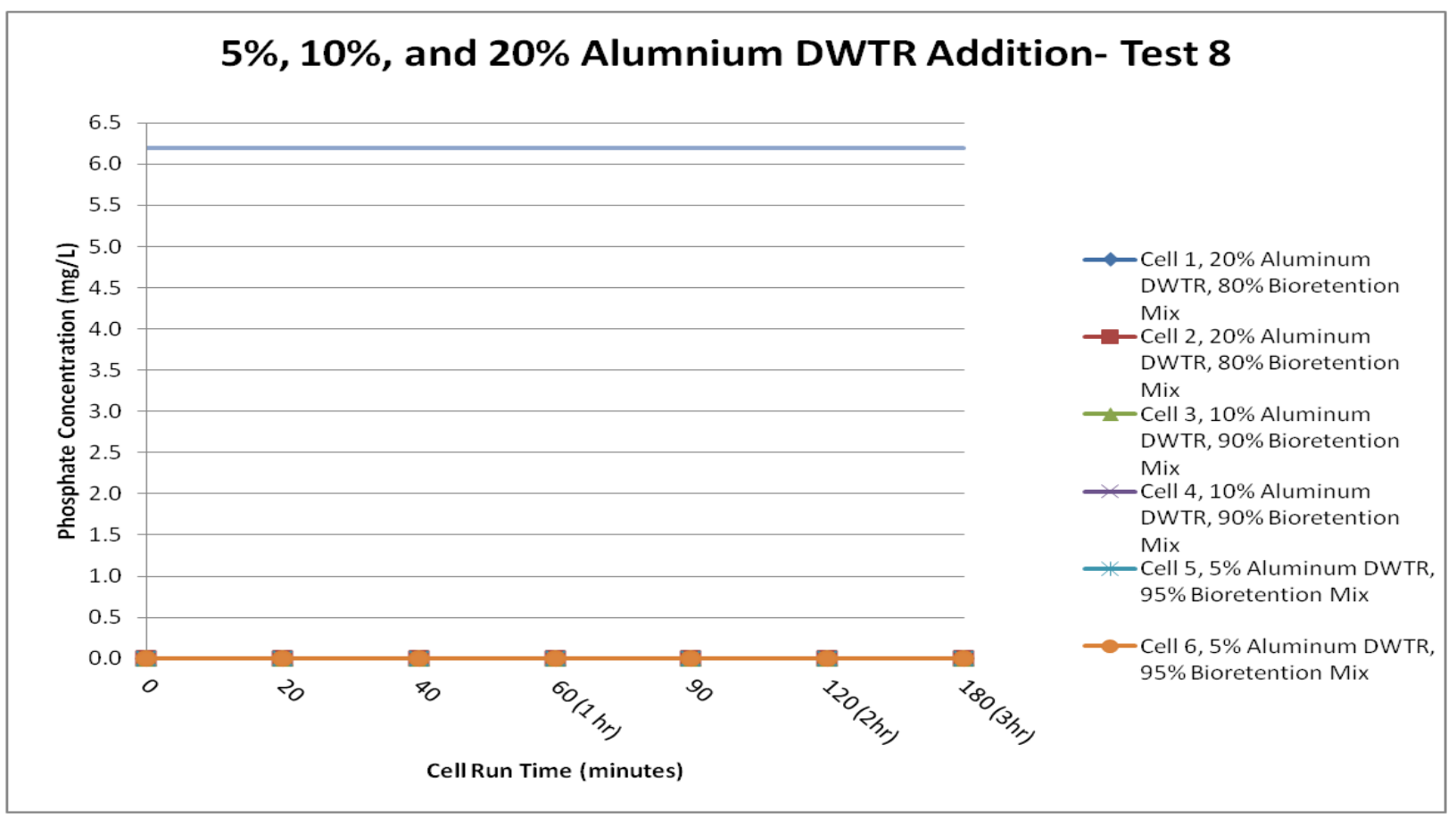

Figure 5- 6: Bioretention Cell Test 8 - 5, 10, and 20\% Aluminum DWTR Addition, $6.2 \mathrm{mg} / \mathrm{L}$ phosphorus in influent water at $60 \mathrm{~mL} / \mathrm{min}$ 


\subsection{Discussion}

Overall it has been shown in this testing that the BSM alone does not have a high phosphorous sorbing capacity (Figure C- 1 through Figure C- 4). The phosphorous concentrations in the effluent can spike while the BSM releases the excess phosphorous. After the excess phosphorous is released, no treatment of the phosphorous takes place within the cell. Although with the addition of plants some phosphorous may be up taken, that was not the scope of this research. To sequester the additional phosphorous, $\mathrm{Ca}, \mathrm{Al}$, and Fe DWTRs were added at a prescribed rate. The testing encompassed mix ratios of $5 \%, 10 \%$, and $20 \%$ DWTR addition. There was a large reduction in effluent flow rate for the $\mathrm{Ca}$ at $10 \%$ and $20 \%$ DWTR addition and also the $20 \% \mathrm{Fe}$ addition. The $5 \% \mathrm{Ca}, 5 \%$ and $10 \% \mathrm{Fe}$, and 5\%, 10\%, and 20\% $\mathrm{Al}$ all had minimal flow reduction (Table 5- 2). The maximum amount of DWTR addition for $\mathrm{Ca}$ and Fe should be $10 \%$ due to flow restriction while up to $20 \%$ may be permissible for $\mathrm{Al}$ DWTR solids. The $\mathrm{Ca} \mathrm{Al}$, and $\mathrm{Fe}$ DWTRs both showed ability to sequester the additional phosphorous within the soil and treatment of excess phosphorous from external sources (Figure 5- 3 through Figure 5- 6). As shown in the $\mathrm{Ca}$ and Fe DWTR addition tests, it is possible to have a higher influent phosphorous loading than sorption can handle. Although the DWTR is not "exhausted" it does not have the capability of sorbing as quickly (phosphorous addition rate is higher than sorption rate) which leads to some phosphorous leaving the cell. The Al DWTR addition testing did not show any phosphorous leaving the cell during the entire test. These results are in line with the results from Agyin-Birikorang et al. (2009). AgyinBirikorang et al. (2009) found a reduction of phosphorous from triple-super-phosphate fertilizer to be 76.5\% (Ca-DWTR), 97.5\% (Fe-DWTR), and 99\% (Al-DWTR) while this 
research found a reduction of 54\% (Ca-DWTR), 88\% (Fe-DWTR), and 99\% (Al-

DWTR). The differences could be attributed to differences in source water or amount of coagulant added in the process.

Table 5- 2: Ca-, Fe-, and Al-DWTR Addition Average Effluent Flow from Cells

\begin{tabular}{|c|c|c|c|c|c|c|}
\hline Cell \# & $\begin{array}{c}\text { DWTR } \\
\text { Addition } \\
\text { (Percent) }\end{array}$ & $\begin{array}{c}\text { Average } \\
\text { Effluent Flow } \\
\text { Rate (ml/min) }\end{array}$ & $\begin{array}{c}\text { DWTR } \\
\text { Addition } \\
\text { (Percent) }\end{array}$ & $\begin{array}{c}\text { Average } \\
\text { Effluent Flow } \\
\text { Rate (ml/min) }\end{array}$ & $\begin{array}{c}\text { DWTR } \\
\text { Addition } \\
\text { (Percent) }\end{array}$ & $\begin{array}{c}\text { Average } \\
\text { Effluent Flow } \\
\text { Rate (ml/min) }\end{array}$ \\
\hline Cell 1 & $20 \% \mathrm{Ca}$ & 1 & $20 \% \mathrm{Fe}$ & 5 & $20 \% \mathrm{Al}$ & 60 \\
\hline Cell 2 & $20 \% \mathrm{Ca}$ & 20 & $20 \% \mathrm{Fe}$ & 5 & $20 \% \mathrm{Al}$ & 60 \\
\hline Cell 3 & $10 \% \mathrm{Ca}$ & 12 & $10 \% \mathrm{Fe}$ & 56 & $10 \% \mathrm{Al}$ & 52 \\
\hline Cell 4 & $10 \% \mathrm{Ca}$ & 17 & $10 \% \mathrm{Fe}$ & 38 & $10 \% \mathrm{Al}$ & 59 \\
\hline Cell 5 & $5 \% \mathrm{Ca}$ & 47 & $5 \% \mathrm{Fe}$ & 60 & $5 \% \mathrm{Al}$ & 60 \\
\hline Cell 6 & $5 \% \mathrm{Ca}$ & 58 & $5 \% \mathrm{Fe}$ & 60 & $5 \% \mathrm{Al}$ & 60 \\
\hline
\end{tabular}




\subsection{SUMMARY AND FUTURE RESEARCH DIRECTION}

\subsection{Summary}

Orthophosphate (phosphorous) has been shown to degrade stream health through allowing excess growth of algae. To slow the rate of excess phosphorous release to waters, best management practices (BMPs) are used. A BMP may be anything from a pipe to a wetland. One popular type of BMP and the one this research focused on was the bioretention cell. The bioretention cell is created by digging a small pit in the ground, placing a perforated drain at the bottom, and filling with a bioretention soil. The bioretention soil typically will be comprised mainly of sand (up to $80 \%$ ). The bioretention cell soil has shown that phosphorous reduction may not be possible by using the bioretention soil only. To achieve phosphorous reduction, additions must be made to the bioretention soil. One reason the bioretention soil mix does not remove phosphorous is due to the bioretention soil being upwards of $80 \%$ sand which is typically inert. Also, bioretention soils that have a high residual phosphorous content can leach phosphorous over time. Phosphorous leaching was confirmed through lab-scale testing of smaller bioretention cells. In each test it was shown that there was a positive correlation between phosphorous leaching and bioretention soils with no modifications. The lab-scale testing also showed the bioretention soil does little to reduce phosphorous in the effluent water.

To address the phosphorous problem, it has been shown that high valence metals could be used to sorb the phosphorous. Typical metals used in drinking water treatment include iron, aluminum, and calcium were chosen to study. The research focused on Ca-, Fe-, and Al-DWTR phosphorous sorption capacity mixed in a bioretention soil. A DWTR 
is collected from the sludge lagoon at a drinking water treatment plant because typically they are a waste product of the drinking water treatment process. To test how much phosphorous a DWTR can sorb, equilibrium testing was done. Equilibrium testing is completed by letting the DWTR come to an equilibrium state in a phosphorous solution over 24 hours then evaluating how much phosphorous was sorbed by the DWTR. This testing showed the DWTR still had capacity to sorb phosphorous. After equilibrium testing, the DWTR was evaluated in a bioretention cell. The DWTR was mixed into the bioretention soil at $20 \%, 10 \%$ and $5 \%$ of the entire volume (BSM-DWTR) and tested for the amount of phosphorous uptake at an applied rate of $6.2 \mathrm{mg} / \mathrm{L}$ at $60 \mathrm{~mL} / \mathrm{min}$. During the cell testing with the Fe and Ca DWTR addition, it was found that the DWTR can detrimentally slow infiltration, but reduces overall phosphorous to less than $1 \mathrm{mg} / \mathrm{L}$ over a 3 hour test dosing the soil with $6.2 \mathrm{mg} / \mathrm{L}$ of phosphorous in the influent water. This research has shown DWTRs to be a viable source to reduce phosphorous. Because drinking water treatment varies between each treatment plant, it would be best to do some type of sorption testing before the application into a bioretention soil to check how much would need to be added. 


\subsection{Future Research Direction}

Future research should include plant introduction possibilities with the DWTRs present, and field testing of the 5\%,10\%, and 20\% DWTR additions. Plant introduction is important because most bioretention cells are designed to offer an aesthetic quality with plantings. The plantings would help guide the maximum amount of DWTR possible to put in the bioretention cell. Lastly, field testing can show how weathering of the DWTR mixes affects phosphorous reduction capacity. 


\section{REFERENCES}

Das, A. (2012). Role of Ammonia-Oxidizing Organisms in Nutrient Removal and Methanogens in Greenhouse Gas Emissions from Natural, Constructed Wetlands and Treatment Ponds. (PhD), University of Missouri Columbia, University of Missouri Columbia.

Aguilar, M. I., Sáez, J., Lloréns, M., Soler, A., \& Ortuño, J. F. (2002). Nutrient removal and sludge production in the coagulation-flocculation process. Water Research, 36(11), 2910-2919. doi: http://dx.doi.org/10.1016/S0043-1354(01)00508-5

Agyin-Birikorang, S., \& O'Connor, G. A. (2007). Lability of Drinking Water Treatment Residuals (WTR) Immobilized Phosphorous Aging and pH Effects. J of Environmental Quality, 36, 1076-1085.

Agyin-Birikorang, S., O'Connor, G. A., Jacobs, L. W., Makris, K. C., \& Brinton, S. R. (2007). Longterm phosphorus immobilization by a drinking water treatment residual. [Research Support, U.S. Gov't, Non-P.H.S.]. J Environ Qual, 36(1), 316-323. doi: 10.2134/jeq2006.0162

Agyin-Birikorang, S., O'Connor, G. A., \& Obreza, T. A. (2009). Drinking Water Treatment Residuals to Control Phosphorous in Soils Soil and Water Science (Vol. SL300, pp. 7). University of Florida: University of Florida.

Aslan, A. (2009). Development and Application of Vegetative Buffer Width Modeling using Geogrpahic Information Systems. (MS), University of Missouri Coumbia, University of Missouri Columbia.

Barrett, M., Walsh, P., Jr., J., \& Charbeneau, R. (1998). Performance of Vegetative Controls for Treating Highway Runoff. Journal of Environmental Engineering, 124(11), 1121-1128. doi: doi:10.1061/(ASCE)0733-9372(1998)124:11(1121) 
Bhumbla, D. K. (2013). Phosphorous Index for Nutrient Management, 2013, from http://www.caf.wvu.edu/ forage/phosman/phosman.htm

Brady, N., \& Weil, R. (2008). The Nature and Properties of Soils (14th Edition): Prentice Hall.

Clark, M., \& Acomb, G. (2008). Bioretention Basins/ Rain Gardens. University of Florida.

Council On Environmental Quality, 42 USC 4341 (1970 1970).

Davis, A. P., Shokouhian, M., Sharma, H., \& Minami, C. (2001). Laboratory Study of Biological Retention for Urban Stormwater Management. Water Environment Research, 73(1), 514. doi: $10.2175 / 106143001 \times 138624$

Dayton, E. A., \& Basta, N. T. (2001). Characterization of drinking water treatment residuals for use as a soil substitute. Water Environment Research, 73(1), 52-57.

Dayton, E. A., Basta, N. T., Jakober, C. A., \& Hattey, J. A. (2003). Using treatment residuals to reduce phosphorus in agricultural runoff. American Water Works Association. Journal, 95(4), 151.

Deposit of Refuse in Navigable Waters Generally, 33 USC 407 (1899).

Dietz, M. E., \& Clausen, J. C. (2005). A Field Evaluation of Rain Garden Flow and Pollutant Treatment. Water, Air, and Soil Pollution, 167(1), 123-138. doi: 10.1007/s11270-0058266-8

District, S. L. M. S. (2012). Landscape Guide For Stormwater Best Management Practice Design (2 ed.): St Louis Metropolitan Sewer District.

Douglas, J. (1966). Appellant V Standard Oil Company, 384 US 224, from http://www.law.cornell.edu/supremecourt/text/384/224\#writing-type-1-DOUGLAS 
Ebeling, J. M., Sibrell, P. L., Ogden, S. R., \& Summerfelt, S. T. (2003). Evaluation of chemical coagulation-flocculation aids for the removal of suspended solids and phosphorus from intensive recirculating aquaculture effluent discharge. Aquacultural Engineering, 29(12), 23-42. doi: http://dx.doi.org/10.1016/S0144-8609(03)00029-3

Edzwald, J. K. (1993). Coagulation in Drinking Water Treatment: Particles, Organics, and Coagulants. Water Science Technology, 27(11), 21-35.

Environment, M. D. o. t. (2009). Maryland Stormwater Design Manual, Volume I and II. Maryland.

Environmental Protection Agency, U. E. (1999). Storm Water Technology Fact Sheet. (EPA 832-F99-012). EPA: EPA.

Environmental Protection Agency, U. E. (2003). A Citizen's Guide to Understanding Stormwater. EPA website: EPA.

Environmental Protection Agency, U. E. (2012a). National Menu of Stormwater Best Management Practices, 2013, from http://cfpub.epa.gov/npdes/stormwater/menuofbmps/

Environmental Protection Agency, U. E. (2012b). Phosphorous. EPA Website: EPA Retrieved from http://water.epa.gov/type/rsl/monitoring/vms56.cfm.

Environmental Protection Agency, U. E. (2012c). Stormwater Management, 2013, from http://www.epa.gov/greeningepa/stormwater/

Environmental Protection Agency, U. E. (2012d). Stormwater Management Best Practices, 2013, from http://www.epa.gov/oaintrnt/stormwater/best_practices.htm

Environmental Protection Agency, U. E. (2012e). Stormwater Program Retrieved 09/19/2013, 2013, from http://cfpub1.epa.gov/npdes/home.cfm?program_id=6 
Environmental Protection Agency, U. E. (2013a). Best Management Practices (BMPs), 2013, from http://www.epa.gov/nrmrl/wswrd/wq/stormwater/bmp.html

Environmental Protection Agency, U. E. (2013b). Low Impact Development (LID), 2013, from http://water.epa.gov/polwaste/green/

Environmental Protection Agency, U. E. (2013c, 06/24/2013). Stormwater Discharges From Municipal Separate Storm Sewer Systems (MS4s) Retrieved 09/19/2013, 2013, from http://cfpub.epa.gov/npdes/stormwater/munic.cfm

Federal Water Pollution Control Act, 33 USC 1251-1376 (1972).

Fenton, O., Serrenho, A., \& Healy, M. G. (2011). Evaluation of Amendments to Control Phosphorus Losses in Runoff from Dairy-Soiled Water. Water, Air and Soil Pollution, 222(1-4), 185-194. doi: http://dx.doi.org/10.1007/s11270-011-0815-8

Foo, K. Y., \& Hameed, B. H. (2010). Insights into the modeling of adsorption isotherm systems. Chemical Engineering Journal, 156(1), 2-10. doi: http://dx.doi.org/10.1016/j.cej.2009.09.013

Haustein, G. K., Daniel, T. C., Miller, D. M., Moore Jr, P. A., \& McNew, R. W. (2000). Aluminumcontaining residuals influence high phosphorous soils and runoff water quality. J Environ Qual, 29, 1954-1959.

Luoni, S., Amos, C. A., Breshears, K., Huber, J., Jacobs, C., Reyenga, S. M., ... Shannon, J. (2011). Low Impact Development: a design manual for urban areas. University of Arkansas: Fay Jones School of Architecture, University of Arkansas.

Ma, J., Lenhart, J. H., Pedrick, J., \& Tracy, K. (2010). Stormwater Phosphorous Removal Using an Innovative Filtration Media. Paper presented at the World Environment and Water Resources Congress 2010.

Municipal and Industrial Stormwater Discharges, 33 USC 1342, subheading P, (1994). 
Nathan, M. V. (2009). Soils, Plant Nutrition, and Nutrient Management. Master Gardener Core Manual, 2013, from http://extension.missouri.edu/publications/DisplayPub.aspx?P=MG4

National Environmental Policy Act, 42 USC 4321 (1969 1970).

National Pollution Discharge Elimination System, 33 USC 1342 (1972).

Novak, J. W., \& Watts, D. W. (2004). Increasing The Phosphorous Sorption Capacity Of Southeastern Coastal Plant Soils Using Water Treatment Residuals. Soil Science, 169(3), 206 - 214. doi: 10.1097/01.ss.0000122522.03492.30

NRCS. (2004). Soil Survey Laboratory Methods Manual, Soil Survey Investigations Report No. 42 (Vol. 4). NRCS: NRCS.

Peleka, E. N., \& Deliyanni, E. A. (2008). Adsorptive removal of phosphates from aqueous solutions. Desalination(245), 357-371. doi: 10.1016/j.desal.200

Qasim, S. R., Motley, E. M., \& Zhu, G. (2002). Water Works Engineering Planning, Design, and Operation. New Jersey: Prentice Hall Inc.

Razali, M., Zhao, Y. Q., \& Bruen, M. (2007). Effectiveness of a drinking-water treatment sludge in removing different phosphorus species from aqueous solution. Separation and Purification Technology, 55(3), 300-306. doi: http://dx.doi.org/10.1016/j.seppur.2006.12.004

Reorginization Plan of 1970, 116 Congressional Record H 6523; House Doc. Nos. 91-364, 91-365, 91-366 Stat. (1970).

Sansalone, J., Kuang, X., \& Ranieri, V. (2008). Permeable Pavement as a Hydraulic and Filtration Interface for Urban Drainage. Journal of Irrigation and Drainage Engineering, 134(5), 666-674. doi: doi:10.1061/(ASCE)0733-9437(2008)134:5(666) 
St. Louis Metropolitan Sewer District, S. M. (2010). Bioretention for Parking Island Typical Section Detail 7. StL MSD Engineering BMP Toolbox Website: StL MSD.

Stange, C. (2007). Rain Gardens; Capturing and Using the Rains of the Great Plains. North Dakota: USDA-NRCS.

United States, Appellant, v. Standard Oil Company, No. 384 US 224 (86 Supreme Court 1966).

United States, Petitioner, v. Republic Steel Corp. et. al., No. 362 US 482 (80 Supreme Court 1960).

US EPA, O. o. W. (1999). Determination of inorganic anions in drinking water by ion chromatography Method 300.1 (pp. 40). U.S. Environmental Protection Agency: US EPA.

Vijayaraghavan, K., Padmesh, T. V. N., Palanivelu, K., \& Velan, M. (2006). Biosorption of nickel(II) ions onto Sargassum wightii: Application of two-parameter and three-parameter isotherm models. Journal of Hazardous Materials, 133(1-3), 304-308. doi: http://dx.doi.org/10.1016/j.jhazmat.2005.10.016

Wikipedia. (2002). Grass lined channel NRCS, from http://en.wikipedia.org/wiki/File:Grass_lined_channel_NRCS.jpg

Wikipedia. (2005). Riparian strip, from http://en.wikipedia.org/wiki/File:Riparian_strip.jpg

Wikipedia. (2006a). Dry Pond, from http://en.wikipedia.org/wiki/File:Dry_pond.jpg

Wikipedia. (2006b). Parking Lot - San Jose, CA March 3, 2006, from http://en.wikipedia.org/wiki/File:P3030027ParkingLot_wb.jpg

Wikipedia. (2007). Trounce Pond, 2013, from http://en.wikipedia.org/wiki/File:Trounce_Pond.jpg

Wikipedia. (2008). Tourbière 03 - Parc de Frontenac - Juillet 2008; Wetland in Frontenac National Park, from http://en.wikipedia.org/wiki/File:Tourbi\%C3\%A8re_03__Parc_de_Frontenac_-_Juillet_2008.jpg 
Wikipedia. (2009). Installation of Steel Pipe, 2013, from http://en.wikipedia.org/wiki/File:Encanamento.JPG

Wikipedia. (2011). Permeable paver demonstration, from http://en.wikipedia.org/wiki/File:Permeable_paver_demonstration.jpg

Wikipedia. (2012, Jan 31, 2012). Diagram of zeta potential and slipping planeV2 2. 2013, from http://en.wikipedia.org/wiki/File:Diagram_of_zeta_potential_and_slipping_planeV2.svg

Yang, Y., Zhao, Y. Q., Babatunde, A. O., Wang, L., Ren, Y. X., \& Han, Y. (2006). Characteristics and mechanisms of phosphate adsorption on dewatered alum sludge. Separation and Purification Technology, 51(2), 193-200. doi: http://dx.doi.org/10.1016/j.seppur.2006.01.013

Yao, Y., Gao, B., Chen, J., \& Yang, L. (2013). Engineered Biochar Reclaiming Phosphate from Aqueous Solutions: Mechanisms and Potential Application as a Slow-Release Fertilizer. Environmental Science \& Technology, 47(15), 8700-8708. doi: 10.1021/es4012977

Zhou, Q., Wang, X., Liu, J., \& Zhang, L. (2012). Phosphorus removal from wastewater using nanoparticulates of hydrated ferric oxide doped activated carbon fiber prepared by Sol-Gel method. Chemical Engineering Journal, 200-202(0), 619-626. doi: http://dx.doi.org/10.1016/j.cej.2012.06.123 


\section{Appendix A}

\section{Cell Test Worksheet}

\begin{tabular}{|c|c|c|c|c|}
\hline Cell \#: & & & Date: & \\
\hline Time Started: & & \multicolumn{3}{|c|}{ Time Ended: } \\
\hline Time (minutes) & Time (minutes) & Phosphate & Turbidity & $\mathrm{pH}$ \\
\hline Actual Simulated Rainfall & Sample grabbed & $\mathrm{mg} / \mathrm{L}$ & NTU & \\
\hline \multirow[t]{11}{*}{0} & $\begin{array}{l}\text { (Insert Stock } \\
\text { Solution \#'s) }\end{array}$ & & & \\
\hline & 0 & & & \\
\hline & 20 & & & \\
\hline & 40 & & & \\
\hline & 60 (1 hr) & & & \\
\hline & 90 & & & \\
\hline & $120(2 \mathrm{hr})$ & & & \\
\hline & 180 (3hr) & & & \\
\hline & 240 (4hr) & & & \\
\hline & 300 (5hr) & & & \\
\hline & 360 (6hr) & & & \\
\hline
\end{tabular}

Figure A 1: Stormwater Testing Sampling Sheet 


\section{Appendix B}

\section{Sorption Test Data}

Table B- 1: Phosphorous Sorption Loading Values after 24 Hours for Calcium and Ferric Chloride

\begin{tabular}{|c|c|c|c|}
\hline Type Of Sludge & $\begin{array}{c}\text { Initial } \\
\text { Concentration } \\
\text { of P-Soln }\end{array}$ & $\begin{array}{c}\text { End } \\
\text { Concentration } \\
\text { of P-Soln }\left(\mathrm{C}_{\mathrm{e}}\right)\end{array}$ & $\begin{array}{c}\text { Sorption } \\
\text { loading of } \\
\text { phosphate at } \\
24 \mathrm{hr}\left(\mathrm{q}_{\mathrm{e}}\right)\end{array}$ \\
\hline Lime + IronOxide & $\mathrm{mg} / \mathrm{L}$ & $\mathrm{mg} / \mathrm{L}$ & $\mathrm{mg} / \mathrm{g}$ \\
\hline Lime + IronOxide & 5 & 3.3 & 1.7 \\
\hline Lime + IronOxide & 25 & 8.3 & 1.7 \\
\hline Lime + IronOxide & 50 & 20.3 & 4.7 \\
\hline Lime + IronOxide & 100 & 71.4 & 8.6 \\
\hline Lime + IronOxide & 200 & 173.7 & 22.6 \\
\hline Ferric Chloride + PAC & 5 & 0.4 & 26.3 \\
\hline Ferric Chloride + PAC & 10 & 1.7 & 4.6 \\
\hline Ferric Chloride + PAC & 25 & 9.0 & 16.0 \\
\hline Ferric Chloride + PAC & 50 & 24.9 & 25.1 \\
\hline Ferric Chloride + PAC & 100 & 64.6 & 35.4 \\
\hline Ferric Chloride + PAC & 200 & 162.5 & 37.5 \\
\hline
\end{tabular}


Table B- 2: Phosphorous Sorption Loading Values after 24 Hours for PolyAluminum Chloride

\begin{tabular}{|c|c|c|c|}
\hline Type Of Sludge & $\begin{array}{c}\text { Initial } \\
\text { Concentration of } \\
\text { P-Soln }\end{array}$ & $\begin{array}{c}\text { End } \\
\text { Concentration } \\
\left.\text { of P-Soln ( } \mathrm{C}_{\mathrm{e}}\right)\end{array}$ & $\begin{array}{c}\text { Sorption loading of } \\
\text { phosphate at 24 hr } \\
\left(\mathrm{q}_{\mathrm{e}}\right)\end{array}$ \\
\hline PolyAluminumChloride & 5 & 0.5 & 4.5 \\
\hline PolyAluminumChloride & 10 & 2.5 & 7.5 \\
\hline PolyAluminumChloride & 25 & 11.9 & 13.1 \\
\hline PolyAluminumChloride & 50 & 23.8 & 26.2 \\
\hline PolyAluminumChloride & 100 & 74.9 & 25.1 \\
\hline PolyAluminumChloride & 200 & 177.5 & 22.5 \\
\hline (Retest) PolyAluminumChloride & 5 & 2.6 & 2.4 \\
\hline (Retest) PolyAluminumChloride & 10 & 5.5 & 4.5 \\
\hline (Retest) PolyAluminumChloride & 25 & 18.7 & 6.3 \\
\hline (Retest) PolyAluminumChloride & 50 & 40.6 & 13.2 \\
\hline (Retest) PolyAluminumChloride & 100 & 86.8 & 19.8 \\
\hline (Retest) PolyAluminumChloride & 200 & 180.2 & 2.9 \\
\hline PolyAluminumChloride + CuSO4 & 5 & 2.1 & 5.8 \\
\hline PolyAluminumChloride + CuSO4 & 10 & 4.2 & 12.3 \\
\hline PolyAluminumChloride + CuSO4 & 25 & 12.7 & 16.6 \\
\hline PolyAluminumChloride + CuSO4 & 50 & 33.4 & 24.8 \\
\hline PolyAluminumChloride + CuSO4 & 100 & 75.2 & 28.9 \\
\hline PolyAluminumChloride + CuSO4 & 200 & 171.2 & \\
\hline
\end{tabular}


Table B- 3: Phosphorous Sorption Loading Values after 24 Hours for Aluminum Sulfate (Separate Facilities)

\begin{tabular}{|c|c|c|c|}
\hline Type Of Sludge & $\begin{array}{c}\text { Initial } \\
\text { Concentratio } \\
\mathrm{n} \text { of P-Soln }\end{array}$ & $\begin{array}{c}\text { End } \\
\text { Concentration } \\
\text { of P-Soln }\left(\mathrm{C}_{\mathrm{e}}\right)\end{array}$ & $\begin{array}{c}\text { Sorption } \\
\text { loading of } \\
\text { phosphate at } \\
24 \mathrm{hr}\left(\mathrm{q}_{\mathrm{e}}\right)\end{array}$ \\
\hline Aluminum Sulfate + PAC & 5 & 0.0 & 5.0 \\
\hline Aluminum Sulfate + PAC & 10 & 0.0 & 10.0 \\
\hline Aluminum Sulfate + PAC & 25 & 0.0 & 25.0 \\
\hline Aluminum Sulfate + PAC & 50 & 0.0 & 50.0 \\
\hline Aluminum Sulfate + PAC & 100 & 2.2 & 97.8 \\
\hline Aluminum Sulfate + PAC & 200 & 4.1 & 195.9 \\
\hline Aluminum Sulfate + PAC + Drying Polymer & 5 & 2.6 & 2.4 \\
\hline Aluminum Sulfate + PAC + Drying Polymer & 10 & 5.5 & 4.5 \\
\hline Aluminum Sulfate + PAC + Drying Polymer & 25 & 18.7 & 6.3 \\
\hline Aluminum Sulfate + PAC + Drying Polymer & 50 & 40.6 & 9.4 \\
\hline Aluminum Sulfate + PAC + Drying Polymer & 100 & 86.8 & 13.2 \\
\hline Aluminum Sulfate + PAC + Drying Polymer & 200 & 180.2 & 19.8 \\
\hline
\end{tabular}

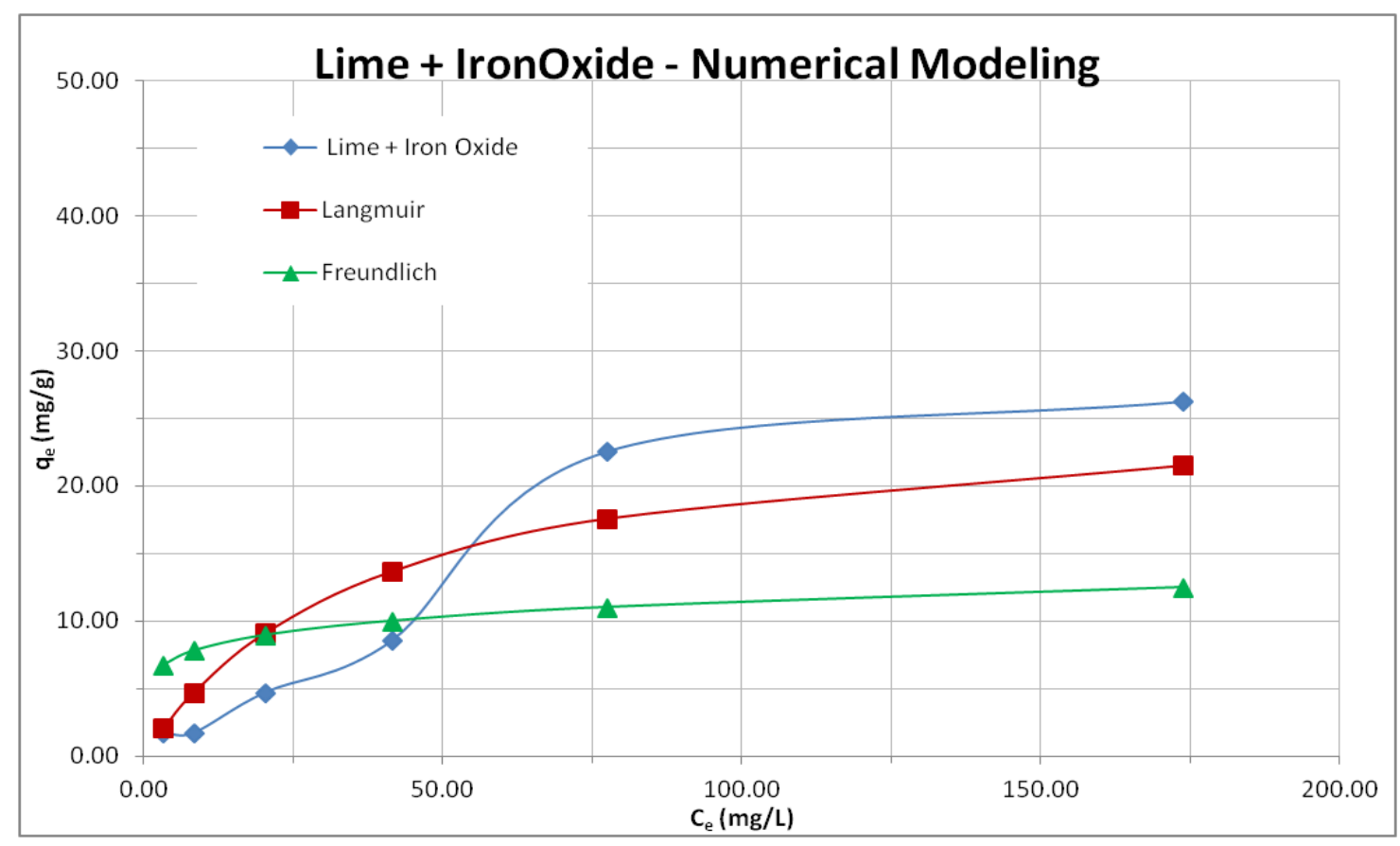

Figure B- 1: Langmuir and Freundlich Isotherm Modeling for Lime DWTR 


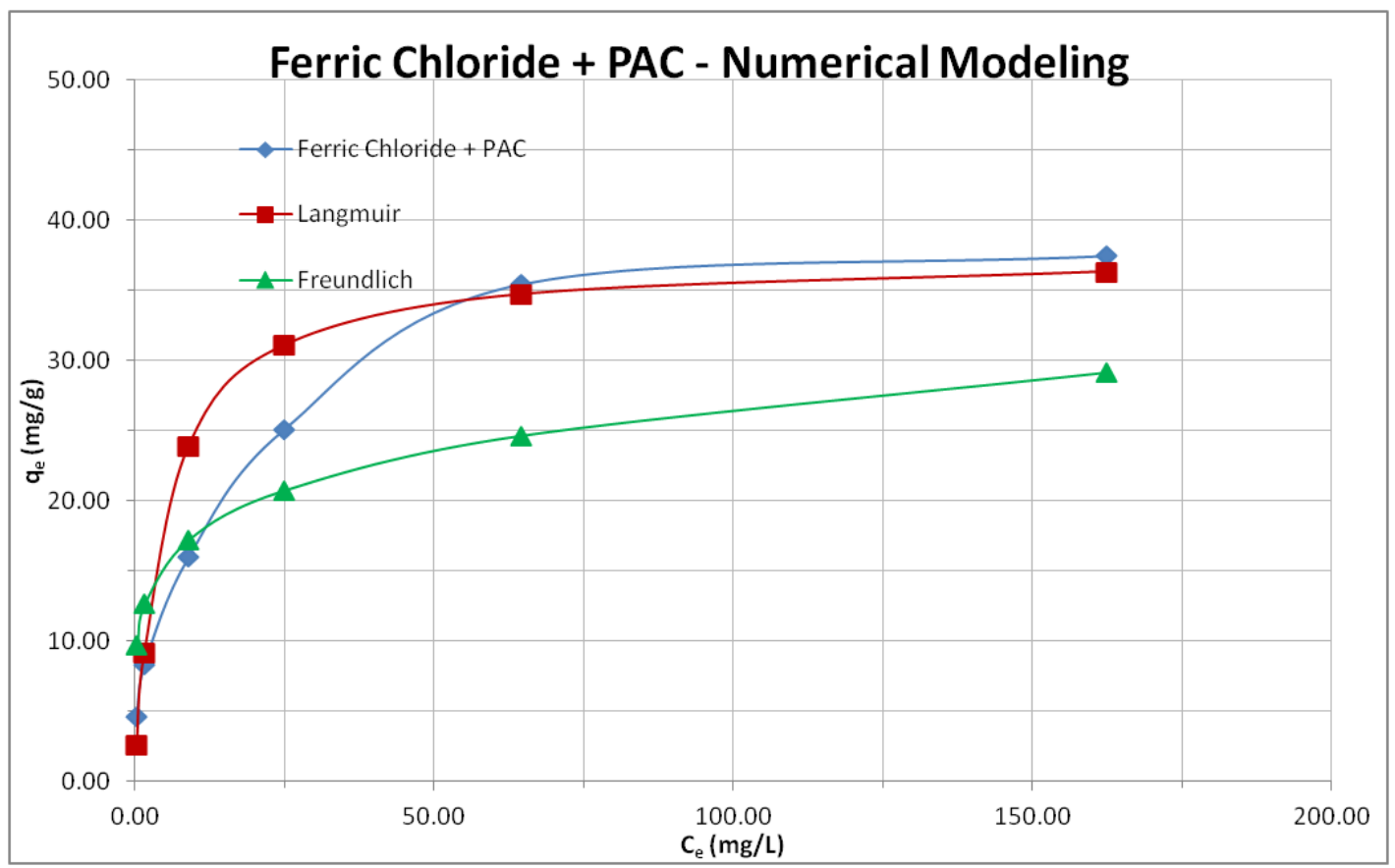

Figure B- 2: Langmuir and Freundlich Isotherm Modeling for Ferric Chloride DWTR

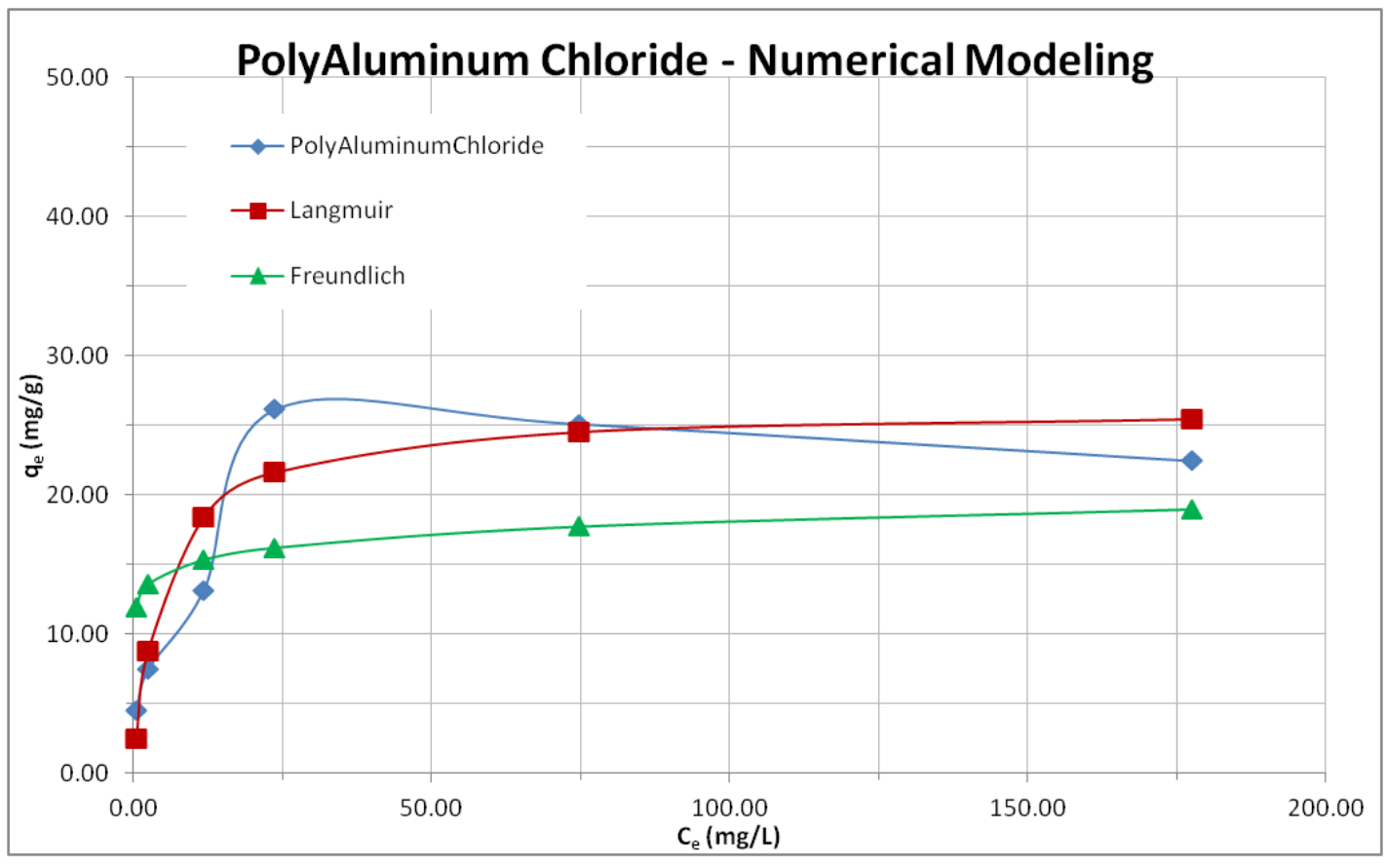

Figure B- 3: Langmuir and Freundlich Isotherm Modeling for Polyaluminum Chloride DWTR 


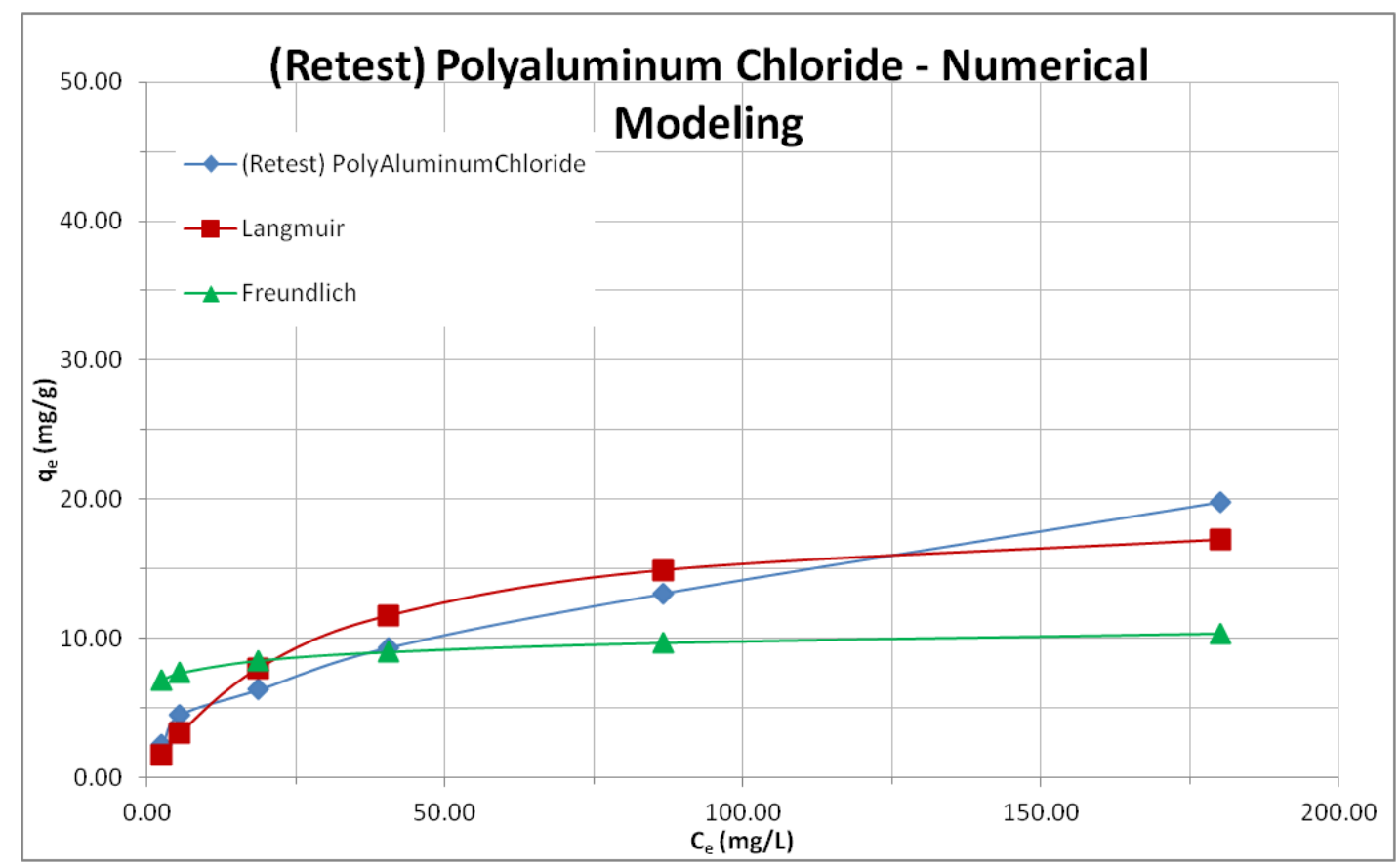

Figure B- 4: Langmuir and Freundlich Isotherm Modeling for (Retest) Polyaluminum Chloride DWTR

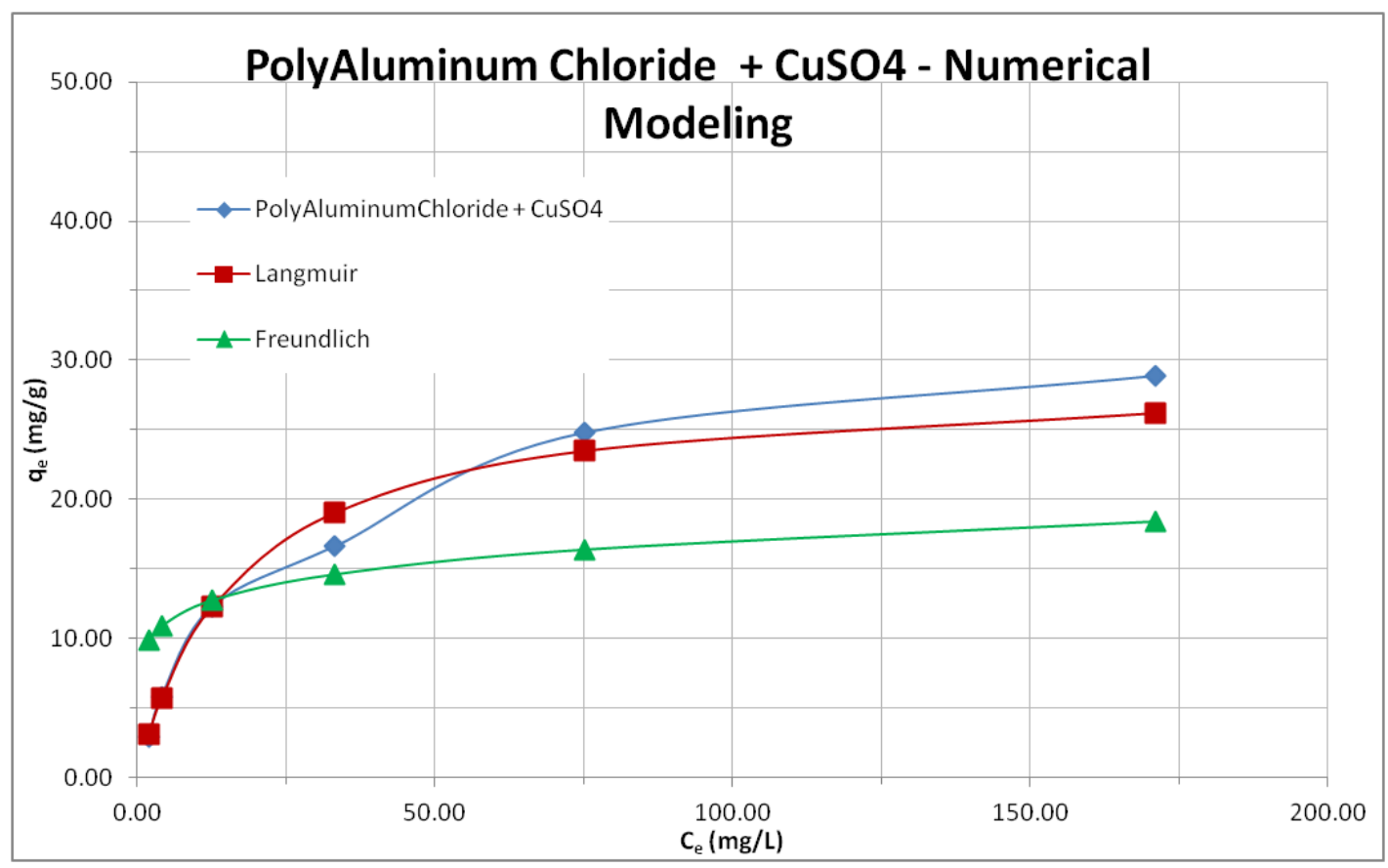

Figure B- 5: Langmuir and Freundlich Isotherm Modeling for Polyaluminum + CuSO4 Chloride DWTR 


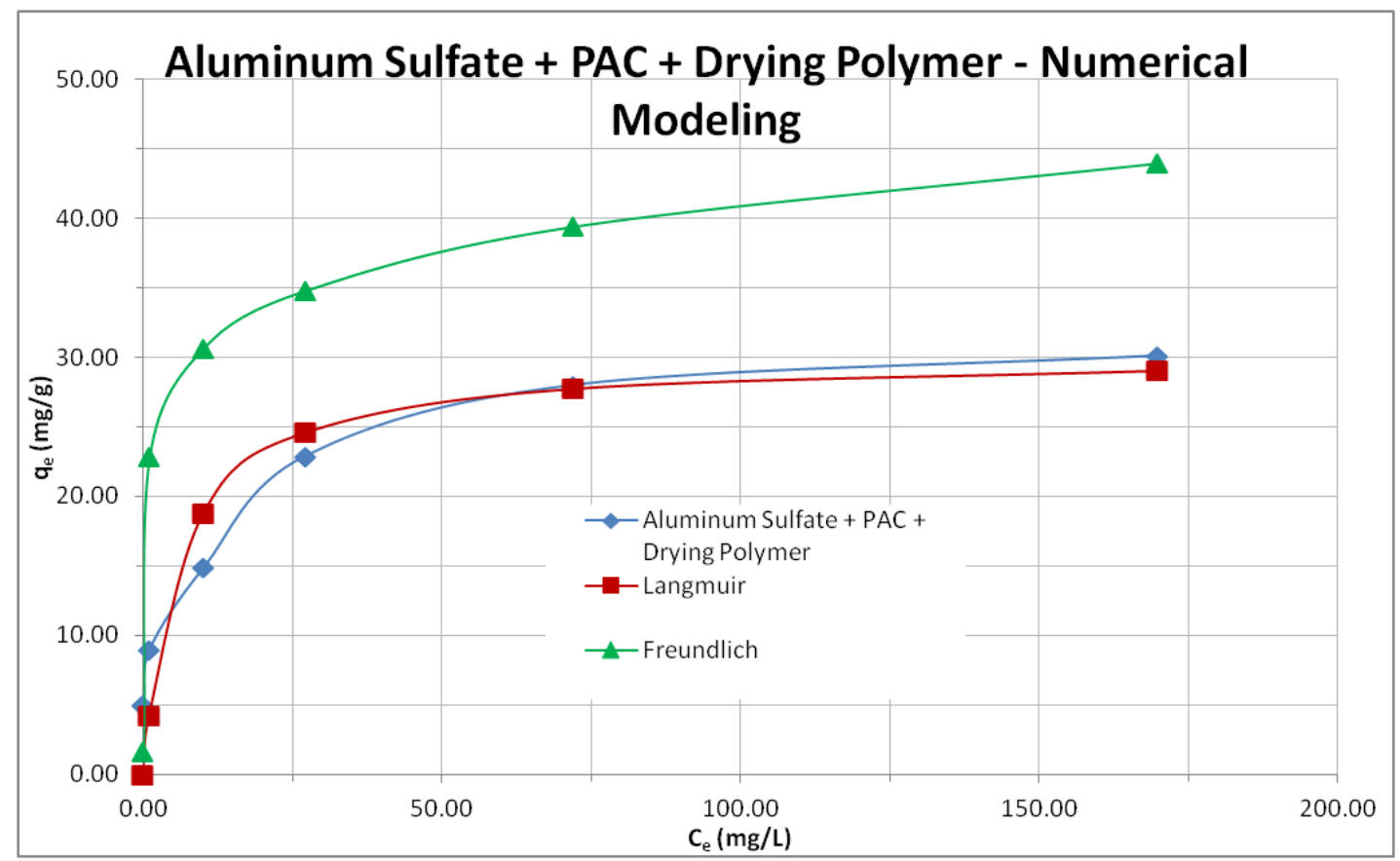

Figure B- 6: Langmuir and Freundlich Isotherm Modeling for Aluminum Sulfate + PAC + Drying Polymer DWTR 


\section{Appendix C}

\section{Cell Column Test Data}

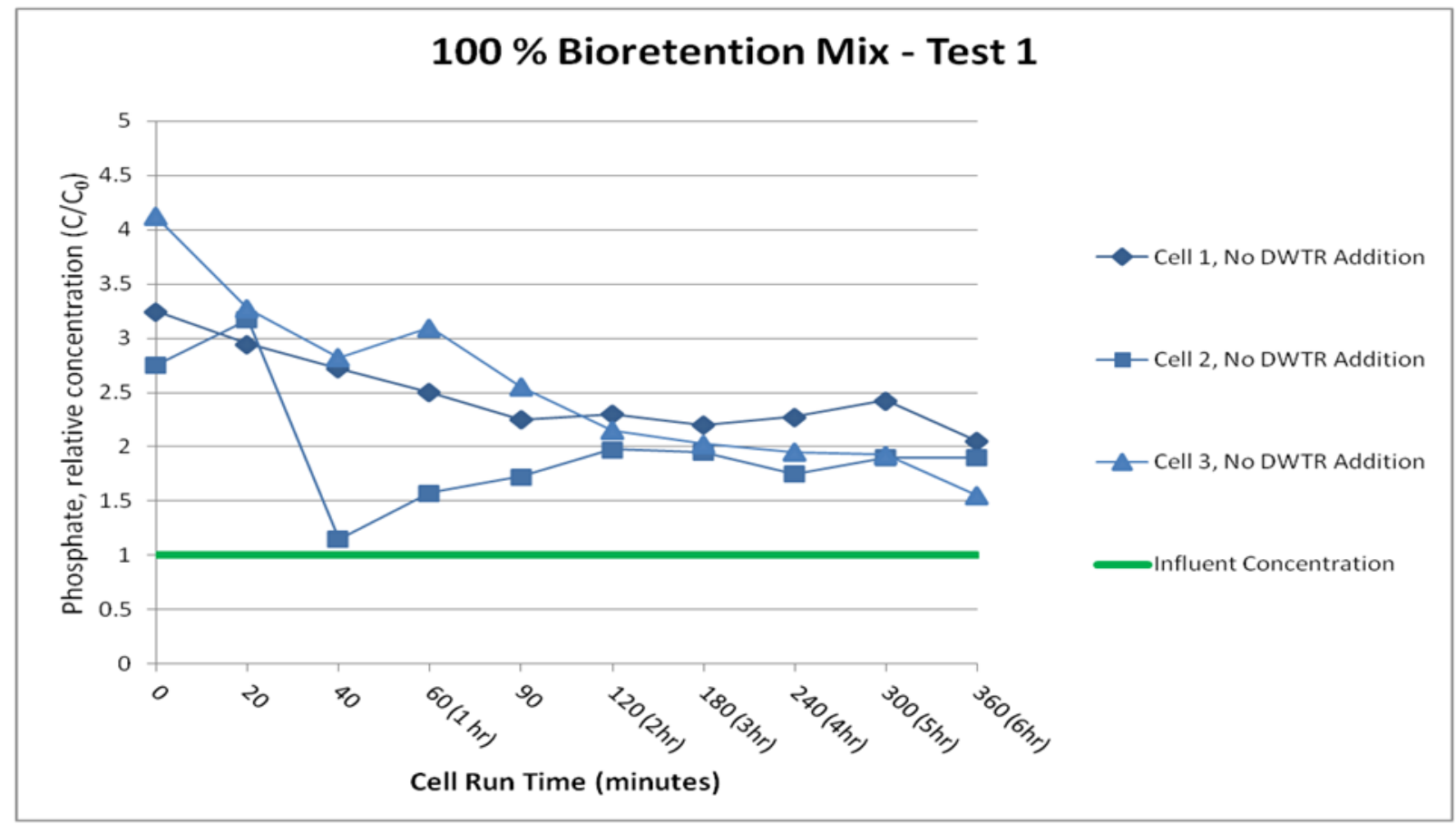

Figure C- 1: Bioretention Cell Test $1-100 \%$ Bioretention Mix, 0.4mg/L of influent phosphorous at $60 \mathrm{~mL} / \mathrm{min}$

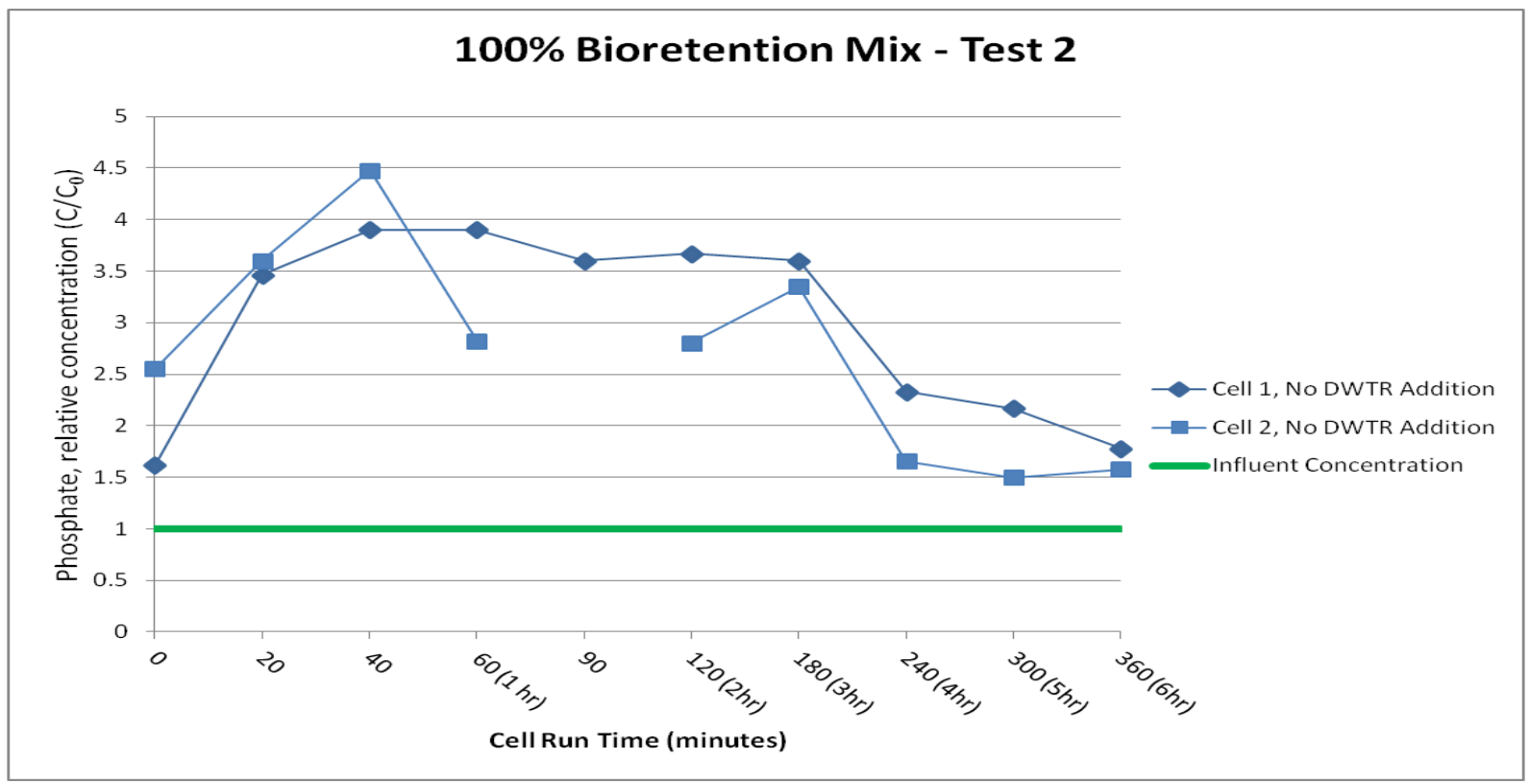


Figure C- 2: Bioretention Cell Test 2 - 100\% Bioretention Mix, 0.4mg/L of influent phosphorous at $60 \mathrm{~mL} / \mathrm{min} ; \mathrm{C} 290 \mathrm{~min}$ point removed due to being unknown outlier

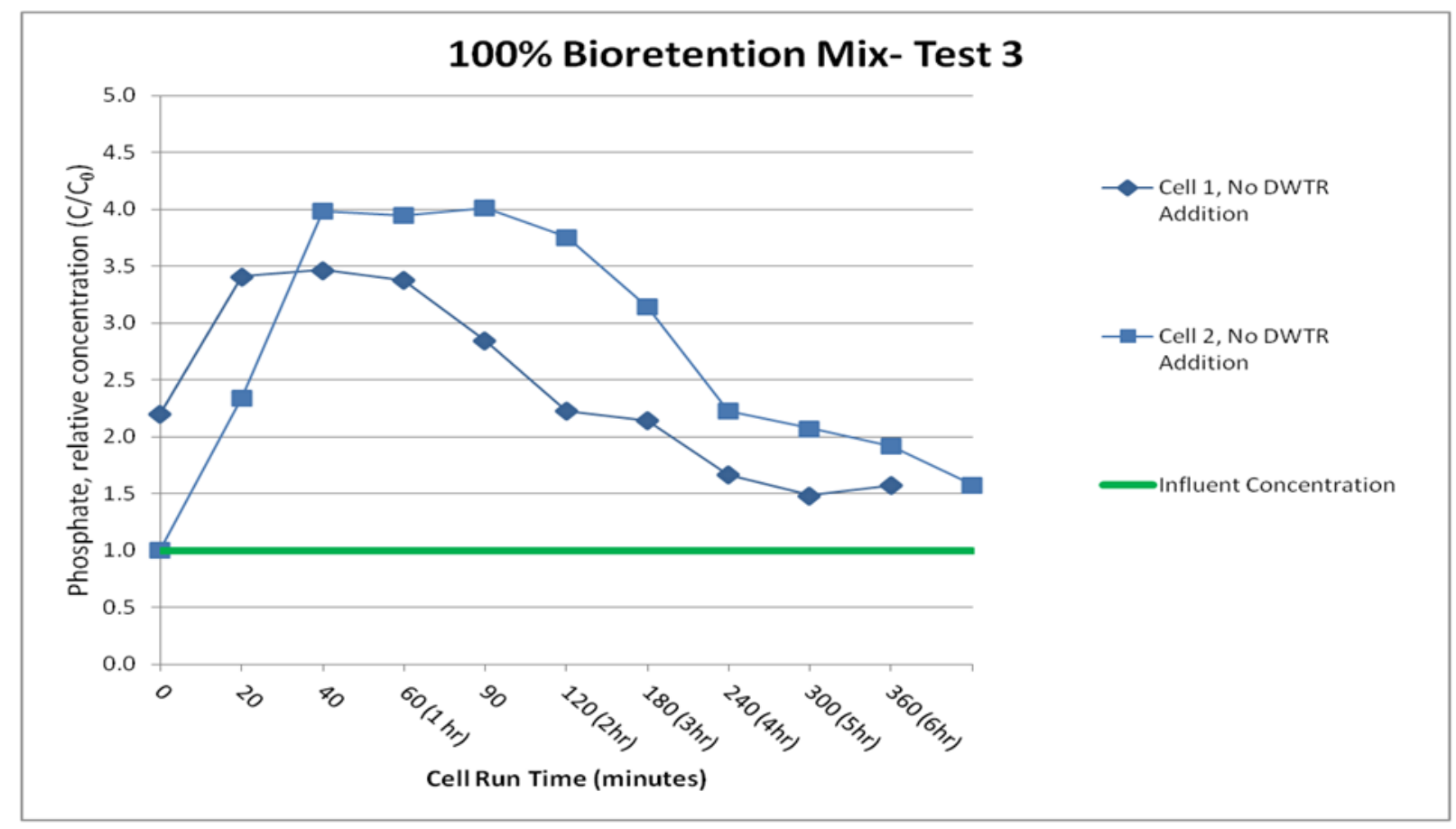

Figure C- 3: Bioretention Cell Test 3 - 100\% Bioretention Mix, 0.4mg/L of influent phosphorous at $60 \mathrm{~mL} / \mathrm{min}$ 


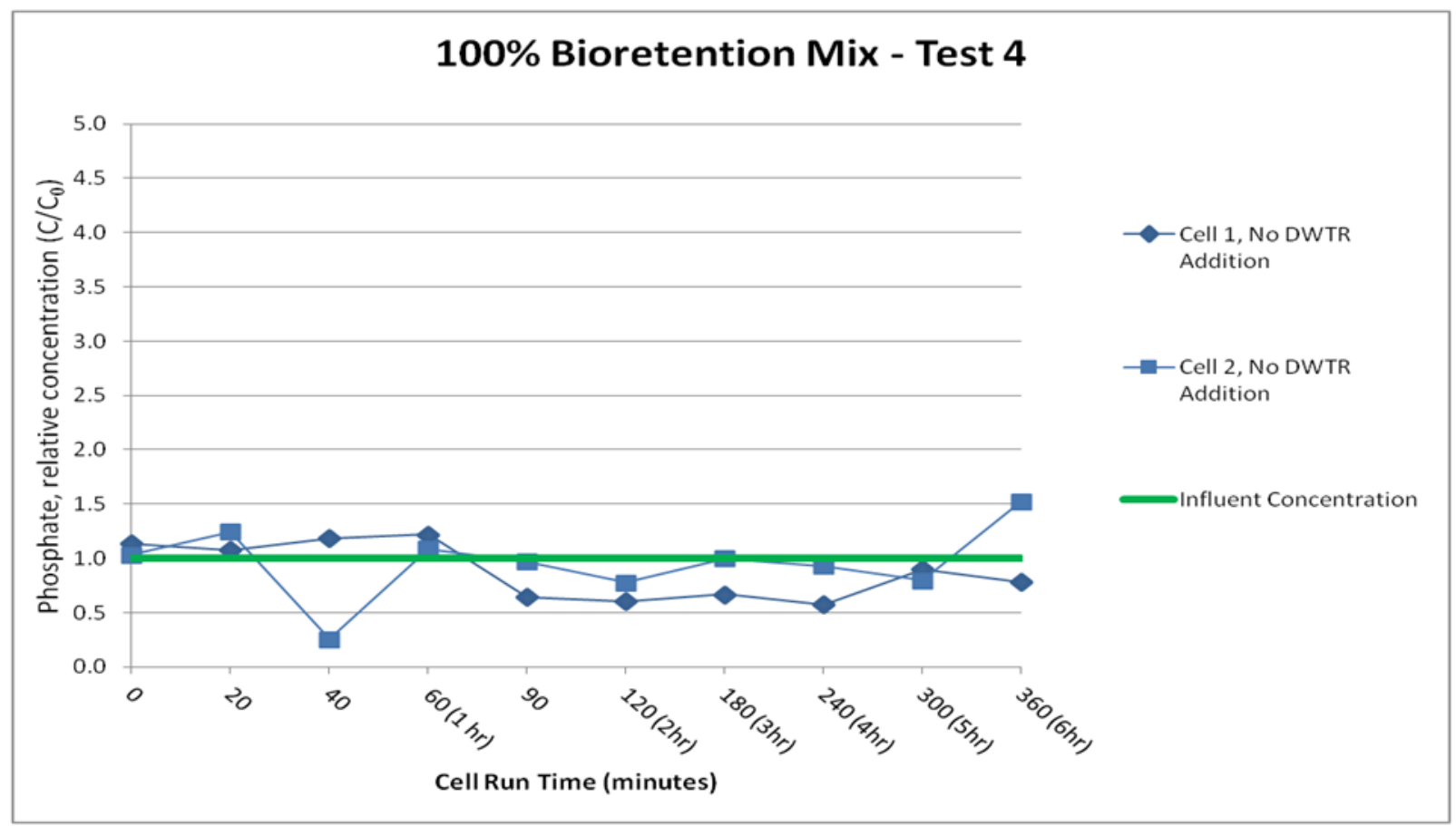

Figure C- 4: Bioretention Cell Test 4 - 100\% Bioretention Mix, 9.6mg/L of influent phosphorous at $60 \mathrm{~mL} / \mathrm{min}$ 
Table C- 1: Test \# 1, Effluent Phosphorous concentration as a function of time for $100 \%$ Bioretention Soil Mix, $0.4 \mathrm{mg} / \mathrm{L}$ Influent Phosphorous at $60 \mathrm{~mL} / \mathrm{min}$

\begin{tabular}{|c|c|c|c|}
\hline Test \# 1 & \multicolumn{3}{|c|}{ Cell \# } \\
\hline & 1 & 2 & 3 \\
\hline Time & \multicolumn{3}{|c|}{ Phosphorous Concentration (mg/L) } \\
\hline Stock & 0.4 & 0.4 & 0.4 \\
\hline 0 & 1.3 & 1.1 & 1.7 \\
\hline 20 & 1.2 & 1.3 & 1.3 \\
\hline 40 & 1.1 & 0.5 & 1.1 \\
\hline $60(1 \mathrm{hr})$ & 1.0 & 0.6 & 1.2 \\
\hline 90 & 0.9 & 0.7 & 1.0 \\
\hline $120(2 \mathrm{hr})$ & 0.9 & 0.8 & 0.9 \\
\hline $180(3 \mathrm{hr})$ & 0.9 & 0.8 & 0.8 \\
\hline $240(4 \mathrm{hr})$ & 0.9 & 0.7 & 0.8 \\
\hline $300(5 \mathrm{hr})$ & 1.0 & 0.8 & 0.8 \\
\hline $360(6 \mathrm{hr})$ & 0.8 & 0.8 & 0.6 \\
\hline & & & \\
\hline
\end{tabular}

Table C- 2: Test \# 2, Effluent Phosphorous concentration as a function of time for $100 \%$ Bioretention Soil Mix, $0.4 \mathrm{mg} / \mathrm{L}$ Influent Phosphorous at $60 \mathrm{~mL} / \mathrm{min}$

\begin{tabular}{|c|c|c|}
\hline Test \# & \multicolumn{2}{|c|}{ Cell \# } \\
\hline & 1 & 2 \\
\hline Time & \multicolumn{2}{|c|}{ Phosphorous Concentration (mg/L) } \\
\hline Stock & 0.4 & 0.4 \\
\hline 0 & 0.6 & 1.0 \\
\hline 20 & 1.4 & 1.4 \\
\hline 40 & 1.6 & 1.8 \\
\hline $60(1 \mathrm{hr})$ & 1.6 & 1.1 \\
\hline 90 & 1.4 & 4.7 \\
\hline $120(2 \mathrm{hr})$ & 1.5 & 1.1 \\
\hline $180(3 \mathrm{hr})$ & 1.4 & 1.3 \\
\hline $240(4 \mathrm{hr})$ & 0.9 & 0.7 \\
\hline $300(5 \mathrm{hr})$ & 0.9 & 0.6 \\
\hline $360(6 \mathrm{hr})$ & 0.7 & 0.6 \\
\hline
\end{tabular}


Table C- 3: Test \# 3, Effluent Phosphorous concentration as a function of time for $100 \%$ Bioretention Soil Mix, $0.4 \mathrm{mg} / \mathrm{L}$ Influent Phosphorous at $60 \mathrm{~mL} / \mathrm{min}$

\begin{tabular}{|c|c|c|}
\hline Test \# 3 & \multicolumn{2}{|c|}{ Cell \# } \\
\hline & 1 & 2 \\
\hline Time & Phosphorous Concentration (mg/L) \\
\hline 0 & 0.9 & 0.9 \\
\hline 20 & 1.4 & 1.6 \\
\hline 40 & 1.4 & 1.6 \\
\hline $60(1 \mathrm{hr})$ & 1.4 & 1.6 \\
\hline 90 & 1.1 & 1.5 \\
\hline $120(2 \mathrm{hr})$ & 0.9 & 1.3 \\
\hline $180(3 \mathrm{hr})$ & 0.9 & 0.9 \\
\hline $240(4 \mathrm{hr})$ & 0.7 & 0.8 \\
\hline $300(5 \mathrm{hr})$ & 0.6 & 0.8 \\
\hline $360(6 \mathrm{hr})$ & 0.6 & 0.6 \\
\hline
\end{tabular}

Table C- 4: Test \# 4, Effluent Phosphorous concentration as a function of time for $100 \%$ Bioretention Soil Mix, $9.6 \mathrm{mg} / \mathrm{L}$ Influent Phosphorous at $60 \mathrm{~mL} / \mathrm{min}$

\begin{tabular}{|c|c|c|}
\hline Test \# 4 & \multicolumn{2}{|c|}{ Cell \# } \\
\hline & 1 & 2 \\
\hline Time & Phosphorous Concentration (mg/L) \\
\hline Stock & 9.6 & 9.9 \\
\hline 0 & 10.9 & 10.2 \\
\hline 20 & 10.3 & 12.3 \\
\hline 40 & 11.4 & 2.5 \\
\hline $60(1 \mathrm{hr})$ & 11.7 & 10.7 \\
\hline 90 & 6.2 & 9.5 \\
\hline $120(2 \mathrm{hr})$ & 5.8 & 7.7 \\
\hline $180(3 \mathrm{hr})$ & 6.4 & 9.8 \\
\hline $240(4 \mathrm{hr})$ & 5.5 & 9.2 \\
\hline $300(5 \mathrm{hr})$ & 8.6 & 7.9 \\
\hline $360(6 \mathrm{hr})$ & 7.5 & 15.0 \\
\hline
\end{tabular}


Table C- 5: Bioretention Cell Tests 1 through 3 Error Analysis of Effluent Phosphorus concentrations - $100 \%$ Bioretention Mix, $0.4 \mathrm{mg} / \mathrm{L}$ of influent phosphorous at $60 \mathrm{~mL} / \mathrm{min}$

\begin{tabular}{|c|c|c|c|c|c|c|c|c|c|}
\hline & Test 1 & Test 1 & Test 1 & Test 2 & Test 2 & Test 3 & Test 3 & $\begin{array}{c}\text { Upper } \\
\text { Limit: }\end{array}$ & $\begin{array}{c}\text { Lower } \\
\text { Limit: }\end{array}$ \\
\hline Time & Cell 1 & Cell 2 & Cell 3 & Cell 1 & Cell 2 & Cell 1 & Cell 2 & $\begin{array}{c}95 \% \\
\text { Confidence }\end{array}$ & $\begin{array}{c}95 \% \\
\text { Confidence }\end{array}$ \\
\hline 0 & 3.3 & 2.8 & 4.1 & 1.6 & 2.6 & 2.2 & 2.3 & 3.4 & 1.9 \\
\hline 20 & 3.0 & 3.2 & 3.3 & 3.5 & 3.6 & 3.4 & 4.0 & 3.7 & 3.1 \\
\hline 40 & 2.7 & 1.2 & 2.8 & 3.9 & 4.5 & 3.5 & 4.0 & 4.2 & 2.2 \\
\hline 60 & 2.5 & 1.6 & 3.1 & 3.9 & 2.8 & 3.4 & 4.0 & 3.8 & 2.3 \\
\hline 90 & 2.3 & 1.7 & 2.6 & 3.6 & 11.9 & 2.8 & 3.8 & 3.6 & 2.0 \\
\hline 120 & 2.3 & 2.0 & 2.2 & 3.7 & 2.8 & 2.2 & 3.1 & 3.2 & 2.0 \\
\hline 180 & 2.2 & 2.0 & 2.0 & 3.6 & 3.3 & 2.1 & 2.2 & 3.1 & 1.9 \\
\hline 240 & 2.3 & 1.8 & 2.0 & 2.3 & 1.7 & 1.7 & 2.1 & 2.2 & 1.7 \\
\hline 300 & 2.4 & 1.9 & 1.9 & 2.2 & 1.5 & 1.5 & 1.9 & 2.2 & 1.6 \\
\hline 360 & 2.1 & 1.9 & 1.6 & 1.8 & 1.6 & 1.6 & 1.6 & 1.9 & 1.5 \\
\hline
\end{tabular}

Table C- 6: Test 6, Ca DWTR Pump Turn On and Turn Off Times during Testing at 5\%, $10 \%$, and $20 \%$ DWTR Addition

\begin{tabular}{|c|c|c|c|c|c|c|}
\hline Test \# & $\begin{array}{c}\text { Column } \\
\#\end{array}$ & $\begin{array}{c}\text { Bioretention } \\
\text { Mix (Percent) }\end{array}$ & $\begin{array}{c}\text { DWTR } \\
\text { Addition } \\
\text { (Percent) }\end{array}$ & Pump Speed & $\begin{array}{c}\text { Turn pump } \\
\text { off (minutes } \\
\text { from start of } \\
\text { test) }\end{array}$ & $\begin{array}{c}\text { Turn pump on } \\
\text { (minutes from } \\
\text { start of test) }\end{array}$ \\
\hline 6 & Cell 1 & 80 & 20 as Ca & $60 \mathrm{~mL} / \mathrm{min} @ \mathrm{t}=0$ & - & - \\
\hline & & & & $\begin{array}{c}30 \mathrm{~mL} / \mathrm{min} @ \\
\mathrm{t}=20\end{array}$ & $30 \mathrm{~min}$ & \\
\hline 6 & Cell 2 & 80 & 20 as Ca & $60 \mathrm{~mL} / \mathrm{min} @ \mathrm{t}=0$ & - & - \\
\hline & & & & $\begin{array}{c}30 \mathrm{~mL} / \mathrm{min} @ \\
\mathrm{t}=20\end{array}$ & $150 \mathrm{~min}$ & - \\
\hline 6 & Cell 3 & 90 & 10 as Ca & $60 \mathrm{ml} / \mathrm{min} @ \mathrm{t}=0$ & $28 \mathrm{~min}$ & $108 \mathrm{~min}$ \\
\hline 6 & Cell 4 & 90 & 10 as Ca & $60 \mathrm{ml} / \mathrm{min} @ \mathrm{t}=0$ & $28 \mathrm{~min}$ & $70 \mathrm{~min}$ \\
\hline & & & & & $108 \mathrm{~min}$ & - \\
\hline 6 & Cell 5 & 95 & 5 as Ca & $60 \mathrm{ml} / \mathrm{min} @ \mathrm{t}=0$ & $70 \mathrm{~min}$ & $120 \mathrm{~min}$ \\
\hline & & & & & $165 \mathrm{~min}$ & - \\
\hline 6 & Cell 6 & 95 & 5 as Ca & $60 \mathrm{ml} / \mathrm{min} @ \mathrm{t}=0$ & - & - \\
\hline
\end{tabular}


Table C- 7: Test 7, Fe DWTR Pump Turn On and Turn Off Times during Testing at 5\%, $10 \%$, and $20 \%$ DWTR Addition

\begin{tabular}{|c|c|c|c|c|c|c|}
\hline Test \# & $\begin{array}{c}\text { Column } \\
\#\end{array}$ & $\begin{array}{c}\text { Bioretention } \\
\text { Mix (Percent) }\end{array}$ & $\begin{array}{c}\text { DWTR } \\
\text { Addition } \\
\text { (Percent) }\end{array}$ & Pump Speed & $\begin{array}{c}\text { Turn pump } \\
\text { off (minutes } \\
\text { from start of } \\
\text { test) }\end{array}$ & $\begin{array}{c}\text { Turn pump on } \\
\text { (minutes from } \\
\text { start of test) }\end{array}$ \\
\hline 7 & Cell 1 & 80 & 20 as Fe & $60 \mathrm{ml} / \mathrm{min} @ \mathrm{t}=0$ & $40 \mathrm{~min}$ & $90 \mathrm{~min}$ \\
\hline & & & & & $120 \mathrm{~min}$ & - \\
\hline 7 & Cell 2 & 80 & 20 as Fe & $60 \mathrm{~mL} / \mathrm{min} @ \mathrm{t}=0$ & $60 \mathrm{~min}$ & $90 \min$ \\
\hline & & & & & $120 \mathrm{~min}$ & - \\
\hline 7 & Cell 3 & 90 & 10 as Fe & $60 \mathrm{~mL} / \mathrm{min} @ \mathrm{t}=0$ & - & - \\
\hline 7 & Cell 4 & 90 & 10 as Fe & $60 \mathrm{~mL} / \mathrm{min} @ \mathrm{t}=0$ & $68 \mathrm{~min}$ & $90 \mathrm{~min}$ \\
\hline & & & & & $160 \mathrm{~min}$ & - \\
\hline 7 & Cell 5 & 95 & 5 as Fe & $60 \mathrm{~mL} / \mathrm{min} @ \mathrm{t}=0$ & - & - \\
\hline 7 & Cell 6 & 95 & 5 as Fe & $60 \mathrm{~mL} / \mathrm{min} @ \mathrm{t}=0$ & - & - \\
\hline
\end{tabular}

Table C- 8: Test 8, Al DWTR Pump Turn On and Turn Off Times during Testing at 5\%, $10 \%$, and $20 \%$ DWTR Addition

\begin{tabular}{|c|c|c|c|c|c|c|}
\hline Test \# & Column \# & $\begin{array}{c}\text { Bioretention } \\
\text { Mix } \\
\text { (Percent) }\end{array}$ & $\begin{array}{c}\text { DWTR } \\
\text { Addition } \\
\text { (Percent) }\end{array}$ & Pump Speed & $\begin{array}{c}\text { Turn pump off } \\
\text { (minutes from } \\
\text { start of test) }\end{array}$ & $\begin{array}{c}\text { Turn pump on } \\
\text { (minutes from } \\
\text { start of test) }\end{array}$ \\
\hline 8 & Cell 1 & 80 & 20 as Al & $60 \mathrm{ml} / \mathrm{min} @ \mathrm{t}=0$ & - & - \\
\hline 8 & Cell 2 & 80 & 20 as Al & $60 \mathrm{~mL} / \mathrm{min} @ \mathrm{t}=0$ & - & - \\
\hline 8 & Cell 3 & 90 & 10 as Al & $60 \mathrm{~mL} / \mathrm{min} @ \mathrm{t}=0$ & - & - \\
\hline 8 & Cell 4 & 90 & 10 as Al & $60 \mathrm{~mL} / \mathrm{min} @ \mathrm{t}=0$ & $62 \mathrm{~min}$ & $75 \mathrm{~min}$ \\
\hline & & & & & $120 \mathrm{~min}$ & $135 \mathrm{~min}$ \\
\hline 8 & Cell 5 & 95 & 5 as Al & $60 \mathrm{~mL} / \mathrm{min} @ \mathrm{t}=0$ & - & - \\
\hline 8 & Cell 6 & 95 & 5 as Al & $60 \mathrm{~mL} / \mathrm{min} @ \mathrm{t}=0$ & - & - \\
\hline
\end{tabular}


Table C- 9: Ca-, Fe-, and Al-DWTR Addition Lag Times between Pump Turn-On and Water Flow from Cell

\begin{tabular}{|c|c|c|c|c|c|c|}
\hline Cell \# & $\begin{array}{c}\text { DWTR } \\
\text { Addition } \\
\text { (Percent) }\end{array}$ & $\begin{array}{c}\text { Lag Time } \\
\text { (minutes) }\end{array}$ & $\begin{array}{c}\text { DWTR } \\
\text { Addition } \\
\text { (Percent) }\end{array}$ & $\begin{array}{c}\text { Lag Time } \\
\text { (minutes) }\end{array}$ & $\begin{array}{c}\text { DWTR } \\
\text { Addition } \\
\text { (Percent) }\end{array}$ & $\begin{array}{c}\text { Lag Time } \\
\text { (minutes) }\end{array}$ \\
\hline Cell 1 & $20 \% \mathrm{Ca}$ & 40 & $20 \% \mathrm{Fe}$ & 40 & $20 \% \mathrm{Al}$ & 9 \\
\hline Cell 2 & $20 \% \mathrm{Ca}$ & 26 & $20 \% \mathrm{Fe}$ & 20 & $20 \% \mathrm{Al}$ & 9 \\
\hline Cell 3 & $10 \% \mathrm{Ca}$ & 18 & $10 \% \mathrm{Fe}$ & 8 & $10 \% \mathrm{Al}$ & 8 \\
\hline Cell 4 & $10 \% \mathrm{Ca}$ & 18 & $10 \% \mathrm{Fe}$ & 8 & $10 \% \mathrm{Al}$ & 8 \\
\hline Cell 5 & $5 \% \mathrm{Ca}$ & 8 & $5 \% \mathrm{Fe}$ & 8 & $5 \% \mathrm{Al}$ & 8 \\
\hline Cell 6 & $5 \% \mathrm{Ca}$ & 7 & $5 \% \mathrm{Fe}$ & 8 & $5 \% \mathrm{Al}$ & 6 \\
\hline
\end{tabular}

Table C- 10: Test \# 6, Effluent Phosphorus when the total mix is 5\%, 10\%, and 20\% Ca-DWTR, $6.2 \mathrm{mg} / \mathrm{L}$ Influent Phosphorous at 60mL/min; Cell 1 had intermittent flow

\begin{tabular}{|c|c|c|c|c|c|c|}
\hline Test \# 6 & \multicolumn{7}{|c|}{ Cell \# } \\
\hline & 1 (20\%) & 2 (20\%) & 3 (10\%) & $4(10 \%)$ & $5(5 \%)$ & $6(5 \%)$ \\
\hline Time & \multicolumn{7}{|c|}{ Phosphorous Concentration (mg/L) } \\
\hline Stock & 6.2 & 6.2 & 6.2 & 6.2 & 6.2 & 6.2 \\
\hline 0 & 0.1 & 0.1 & 3.1 & 0.0 & 0.4 & 0.3 \\
\hline 20 & - & 0.1 & 6.1 & 0.0 & 0.8 & 1.6 \\
\hline 40 & - & 0.1 & 5.6 & 0.0 & 1.2 & 2.2 \\
\hline $60(1 \mathrm{hr})$ & - & 0.6 & 5.8 & 0.3 & 2.2 & 2.5 \\
\hline 90 & - & 1.0 & 6.5 & 0.3 & 1.7 & 2.7 \\
\hline 120 & 0.1 & 0.6 & 5.3 & 0.4 & 2.0 & 3.0 \\
\hline 180 & - & 0.8 & 5.7 & 0.4 & 2.2 & 3.3 \\
\hline
\end{tabular}


Table C- 11: Test \# 7, Effluent Phosphorus when the total mix is 5\%, 10\%, and $20 \%$ Fe-DWTR, $6.2 \mathrm{mg} / \mathrm{L}$ Influent Phosphorous at $60 \mathrm{~mL} / \mathrm{min}$

\begin{tabular}{|c|c|c|c|c|c|c|}
\hline Test \# 7 & \multicolumn{7}{|c|}{ Cell \# } \\
\hline & $1(20 \%)$ & $2(20 \%)$ & $3(10 \%)$ & $4(10 \%)$ & $5(5 \%)$ & $6(5 \%)$ \\
\hline Time & \multicolumn{7}{|c|}{ Phosphorous Concentration (mg/L) } \\
\hline Stock & 6.2 & 6.2 & 6.2 & 6.2 & 6.2 & 6.2 \\
\hline 0 & 0 & 0 & 0 & 0 & 0 & 0 \\
\hline 20 & 0 & 0 & 0 & 0 & 0 & 0 \\
\hline 40 & 0 & 0 & 0 & 0 & 0 & 0 \\
\hline $60(1 \mathrm{hr})$ & 0 & 0 & 0 & 0 & 0 & 0 \\
\hline 90 & 0 & 0 & 0 & 0 & 0 & 0.3 \\
\hline 120 & 0 & 0 & 0 & 0 & 0.2 & 0.4 \\
\hline 180 & 0 & 0 & 0 & 0 & 0.5 & 1.1 \\
\hline
\end{tabular}

Table C- 12: Test \# 8, Effluent Phosphorus when the total mix is 5\%, 10\%, and $20 \%$ Al-DWTR, $6.2 \mathrm{mg} / \mathrm{L}$ Influent Phosphorous at $60 \mathrm{~mL} / \mathrm{min}$

\begin{tabular}{|c|c|c|c|c|c|c|}
\hline Test \# & \multicolumn{7}{|c|}{ Cell \# } \\
\hline & $1(20 \%)$ & $2(20 \%)$ & $3(10 \%)$ & $4(10 \%)$ & $5(5 \%)$ & $6(5 \%)$ \\
\hline Time & \multicolumn{7}{|c|}{ Phosphorous Concentration (mg/L) } \\
\hline Stock & 6.2 & 6.2 & 6.2 & 6.2 & 6.2 & 6.2 \\
\hline 0 & 0 & 0 & 0 & 0 & 0 & 0 \\
\hline 20 & 0 & 0 & 0 & 0 & 0 & 0 \\
\hline 40 & 0 & 0 & 0 & 0 & 0 & 0 \\
\hline $60(1 \mathrm{hr})$ & 0 & 0 & 0 & 0 & 0 & 0 \\
\hline 90 & 0 & 0 & 0 & 0 & 0 & 0 \\
\hline 120 & 0 & 0 & 0 & 0 & 0 & 0 \\
\hline 180 & 0 & 0 & 0 & 0 & 0 & 0 \\
\hline
\end{tabular}




\section{Appendix D}

Soil Characterization Data

Table D- 1: Size Characterization of DWTR Compared to a BMP Soil. Pre - Before Column Testing, Post - After Column Testing

\begin{tabular}{|c|c|c|c|}
\hline & & \% of Total & \\
\hline & $<.002 \mathrm{~mm}$ & $.002-.05$ & $.05-2.00$ \\
\hline & Clay & Silt & Sand \\
\hline $5 \%$ Ca Pre & 3.4 & 20.1 & 76.5 \\
\hline $5 \%$ Ca Post & 4.9 & 19.15 & 75.95 \\
\hline $10 \%$ Ca Pre & 8.2 & 19.9 & 71.9 \\
\hline $10 \%$ Ca Post & 7.1 & 19.75 & 73.15 \\
\hline $20 \%$ Ca Pre & 2.1 & 16.2 & 81.7 \\
\hline $20 \%$ Ca Post & 6.4 & 28.1 & 65.5 \\
\hline $5 \%$ Fe Pre & 1.6 & 4.4 & 94 \\
\hline $5 \%$ Fe Post & 1.25 & 6.65 & 92.1 \\
\hline $10 \%$ Fe Pre & 1.6 & 6.2 & 92.2 \\
\hline $10 \%$ Fe Post & 3.45 & 18.7 & 77.85 \\
\hline $20 \%$ Fe Pre & 2.1 & 16.2 & 81.7 \\
\hline $20 \%$ Fe Post & 3.6 & 18.9 & 77.45 \\
\hline $5 \%$ Al Pre & 0.9 & 4.2 & 94.9 \\
\hline $5 \%$ Al Post & 1.05 & 5.75 & 93.2 \\
\hline $10 \%$ Al Pre & 1.2 & 5.5 & 93.3 \\
\hline $10 \%$ Al Post & 1.4 & 4.9 & 93.7 \\
\hline $20 \%$ Al Pre & 1.6 & 4.3 & 94.1 \\
\hline $20 \%$ Al Post & 1.4 & 5.15 & 93.45 \\
\hline ARC BMP Soil & 6.3 & 17 & 76.7 \\
\hline
\end{tabular}


Table D- 2: Extractable Bases by $\mathrm{NH}_{4} \mathrm{Cl}$ of DWTR Compared to a BMP Soil. Pre - Before Column Testing, Post - After Column Testing

\begin{tabular}{|c|c|c|c|c|c|c|}
\hline & \multicolumn{5}{|c|}{$\mathrm{NH}_{4} \mathrm{Cl}$ Extractable Bases } & \multirow{3}{*}{$\begin{array}{c}\mathrm{NH}_{4} \mathrm{Cl} \\
\text { Extractable } \\
\mathrm{Al}\end{array}$} \\
\hline & \multicolumn{4}{|c|}{ meq / $100 \mathrm{~g}$} & \multirow{2}{*}{$\begin{array}{c}\text { Sum of } \\
\text { Bases }\end{array}$} & \\
\hline & $\mathrm{Ca}$ & $\mathrm{Mg}$ & $\mathrm{Na}$ & K & & \\
\hline 5\% Ca Pre & 27 & 3.5 & 0.4 & 1.7 & 32.6 & 0 \\
\hline $5 \%$ Ca Post & 28.15 & 4.2 & 0.3 & 0.55 & 33.2 & 0 \\
\hline 10\% Ca Pre & 29.9 & 4.6 & 0.5 & 2.2 & 37.2 & 0 \\
\hline $10 \%$ Ca Post & 28.6 & 4.05 & 0.3 & 1.2 & 34.15 & 0 \\
\hline $20 \%$ Ca Pre & 20.5 & 3.1 & 0.4 & 1.2 & 25.2 & 0 \\
\hline $20 \%$ Ca Post & 27.7 & 3.95 & 0.45 & 1.15 & 33.25 & 0 \\
\hline 5\% Fe Pre & 10.1 & 1.7 & 0.3 & 0.1 & 12.2 & 0 \\
\hline $5 \%$ Fe Post & 10.4 & 1.7 & 0.2 & 0.1 & 12.4 & 0 \\
\hline $10 \%$ Fe Pre & 9.1 & 1.6 & 0.2 & 0.1 & 11 & 0 \\
\hline $10 \%$ Fe Post & 21.7 & 3.6 & 0.65 & 0.5 & 26.45 & 0 \\
\hline $20 \%$ Fe Pre & 20.5 & 3.1 & 0.4 & 1.2 & 25.2 & 0 \\
\hline $20 \%$ Fe Post & 19.75 & 2.75 & 0.45 & 1.1 & 24.05 & 0 \\
\hline 5\% Al Pre & 5.5 & 1.3 & 0.1 & 0.1 & 7 & 0 \\
\hline $5 \%$ Al Post & 4.7 & 1.05 & 0.15 & 0.05 & 5.95 & 0 \\
\hline $10 \%$ Al Pre & 6.7 & 1.4 & 0.3 & 0.1 & 8.5 & 0 \\
\hline $10 \%$ Al Post & 5.8 & 1.35 & 0.15 & 0.05 & 7.35 & 0 \\
\hline $20 \%$ Al Pre & 5.6 & 0.9 & 0.2 & 0.1 & 6.8 & 0 \\
\hline $20 \%$ Al Post & 5.35 & 1 & 0.25 & 0 & 6.6 & 0 \\
\hline ARC BMP Soil & 10.7 & 1.3 & 0 & 0.1 & 12.1 & 0 \\
\hline
\end{tabular}


Table D- 3: Cation Exchange Capacity of DWTR Compared to a BMP Soil.

Pre - Before Column Testing, Post - After Column Testing

\begin{tabular}{|c|c|c|c|c|c|c|c|c|c|}
\hline & \multirow{2}{*}{\multicolumn{3}{|c|}{$\frac{\text { Cation Exchange Capacity }}{\text { meq / } 100 \mathrm{~g}}$}} & \multirow{3}{*}{$\frac{\% \mathrm{Al}}{\text { Saturation }}$} & \multicolumn{2}{|c|}{ \% Base Saturation } & \multirow{3}{*}{$\begin{array}{c}\% \\
\text { Organic } \\
\text { Carbon }\end{array}$} & \multirow{3}{*}{$\begin{array}{c}\% \\
\text { Inorganic } \\
\text { Carbon }\end{array}$} & \multirow{3}{*}{$\begin{array}{c}\% \\
\text { Total } \\
\text { Carbor }\end{array}$} \\
\hline & & & & & \multirow{2}{*}{$\begin{array}{l}\text { Sum of } \\
\text { Cations }\end{array}$} & \multirow[t]{2}{*}{$\mathrm{NH}_{4} \mathrm{Cl}$} & & & \\
\hline & Sum & $\mathrm{NH}_{4} \mathrm{Cl}$ & Bases+AL & & & & & & \\
\hline 5\% Ca Pre & & 8.3 & 32.6 & 0 & - & 393 & 2.72 & 0.96 & 3.68 \\
\hline $5 \%$ Ca Post & & 10.6 & 33.2 & 0 & - & 313.5 & 2.725 & 0.84 & 3.565 \\
\hline 10\% Ca Pre & & 10.2 & 37.2 & 0 & - & 365 & 3.13 & 1.18 & 4.31 \\
\hline $10 \%$ Ca Post & & 9.7 & 34.15 & 0 & - & 352 & 2.605 & 1.105 & 3.71 \\
\hline 20\% Ca Pre & & 9.1 & 25.2 & 0 & - & 277 & 4.79 & 0.26 & 5.05 \\
\hline $20 \%$ Ca Post & & 8.15 & 33.25 & 0 & - & 414.5 & 2.875 & 1.97 & 4.845 \\
\hline $5 \%$ Fe Pre & & 5.3 & 12.2 & 0 & - & 230 & 1.43 & 0 & 1.43 \\
\hline 5\% Fe Post & & 4.7 & 12.4 & 0 & - & 264.5 & 1.815 & 0 & 1.815 \\
\hline $10 \%$ Fe Pre & & 4.8 & 11 & 0 & - & 229 & 1.74 & 0 & 1.74 \\
\hline $10 \%$ Fe Post & & 11 & 26.45 & 0 & - & 242 & 5.11 & 0.255 & 5.365 \\
\hline $20 \%$ Fe Pre & & 9.1 & 25.2 & 0 & - & 277 & 4.79 & 0.26 & 5.05 \\
\hline $20 \%$ Fe Post & & 8.95 & 24.05 & 0 & - & 268.5 & 4.4 & 0.27 & 4.67 \\
\hline $5 \%$ Al Pre & & 4.1 & 7 & 0 & - & 171 & 1.41 & 0 & 1.41 \\
\hline 5\% Al Post & & 3.55 & 5.95 & 0 & - & 167.5 & 1.245 & 0.115 & 1.36 \\
\hline 10\% Al Pre & & 5.1 & 8.5 & 0 & - & 167 & 1.78 & 0.43 & 2.21 \\
\hline $10 \%$ Al Post & & 4.65 & 7.35 & 0 & - & 159 & 2.495 & 0 & 2.495 \\
\hline $20 \%$ Al Pre & & 4 & 6.8 & 0 & - & 170 & 3.51 & 0 & 3.51 \\
\hline $20 \%$ Al Post & & 4.25 & 6.6 & 0 & - & 155.5 & 3.615 & 0 & 3.615 \\
\hline ARC BMP Soil & & 6.1 & 12.1 & 0 & - & 198 & 1.06 & 0.12 & 1.18 \\
\hline
\end{tabular}


Table D- 4: pH, Plant Available Phosphorus, Total Nitrogen, and Conductivity of DWTR Compared to a BMP Soil. Pre - Before Column Testing, Post - After Column Testing

\begin{tabular}{|c|c|c|c|c|c|c|}
\hline & $\mathbf{p H}$ & $\mathbf{p H}$ & $\mathbf{B r a y} \mathbf{1}$ & $\mathbf{\%}$ & $\mathbf{E C}$ & \\
\hline & salt & water & $\mathbf{P}$ & Total & $\mathrm{dS} / \mathrm{m}$ & Salinity \\
\hline & & & $(\mathrm{ppm})$ & Nitrogen & & \\
\hline $5 \%$ Ca Pre & 7.86 & 8.29 & 0.6 & 0.18 & 1.12 & non-saline \\
\hline $5 \%$ Ca Post & 7.84 & 8.28 & 0.75 & 0.222 & 0.45 & non-saline \\
\hline $10 \%$ Ca Pre & 7.87 & 8.31 & 0.4 & 0.186 & 1.28 & non-saline \\
\hline $10 \%$ Ca Post & 7.9 & 8.44 & 0.5 & 0.18 & 0.545 & non-saline \\
\hline $20 \%$ Ca Pre & 7.88 & 8.28 & 2.4 & 0.219 & 1.02 & non-saline \\
\hline $20 \%$ Ca Post & 8.005 & 8.665 & 0.3 & 0.1675 & 0.55 & non-saline \\
\hline $5 \%$ Fe Pre & 7.59 & 8.06 & 23.5 & 0.049 & 0.35 & non-saline \\
\hline $5 \%$ Fe Post & 7.705 & 8.305 & 44.7 & 0.048 & 0.265 & non-saline \\
\hline $10 \%$ Fe Pre & 7.59 & 8.08 & 20.6 & 0.042 & 0.39 & non-saline \\
\hline $10 \%$ Fe Post & 7.765 & 8.335 & 22.2 & 0.2205 & 0.47 & non-saline \\
\hline $20 \%$ Fe Pre & 7.88 & 8.28 & 2.4 & 0.219 & 1.02 & non-saline \\
\hline $20 \%$ Fe Post & 7.89 & 8.535 & 4.65 & 0.217 & 0.585 & non-saline \\
\hline $5 \%$ Al Pre & 7.52 & 7.99 & 36.4 & 0.075 & 0.28 & non-saline \\
\hline $5 \%$ Al Post & 7.41 & 7.845 & 21.8 & 0.0625 & 0.345 & non-saline \\
\hline $10 \%$ Al Pre & 7.27 & 7.63 & 14.7 & 0.105 & 0.56 & non-saline \\
\hline $10 \%$ Al Post & 7.465 & 7.905 & 17.95 & 0.0755 & 0.325 & non-saline \\
\hline $20 \%$ Al Pre & 7.18 & 7.48 & 10.2 & 0.104 & 0.84 & non-saline \\
\hline $20 \%$ Al Post & 7.36 & 7.795 & 10.35 & 0.1065 & 0.375 & non-saline \\
\hline ARC BMP Soil & 7.49 & 7.98 & 39 & 0.056 & 0.14 & non-saline \\
\hline
\end{tabular}

